\title{
Title: Horizontal transfer of prokaryotic cytolethal distending toxin B genes to eukaryotes
}

Authors: Kirsten I. Verster ${ }^{1, *}$, Jennifer H. Wisecaver ${ }^{2}$, Rebecca P. Duncan ${ }^{1}$, Marianthi

Karageorgi ${ }^{1}$, Andrew D. Gloss ${ }^{3}$, Ellie Armstrong ${ }^{4}$, Donald K. Price ${ }^{5}$, Aruna R. Menon ${ }^{1}$, Zainab

M. Ali ${ }^{1}$, Noah K. Whiteman ${ }^{1, *}$

\section{Affiliations:}

${ }^{1}$ Department of Integrative Biology, University of California - Berkeley, Berkeley, CA

${ }^{2}$ Department of Biochemistry, Purdue University, West Lafayette, IN

${ }^{3}$ Department of Ecology and Evolution, University of Chicago, Chicago, IL

${ }^{4}$ Department of Biology, Stanford University, Stanford, CA

*Correspondence to: kiv@,berkeley.edu (Kirsten I. Verster); whiteman@berkeley.edu (Noah K. Whiteman 


\begin{abstract}
:
Cytolethal distending toxins (CDTs) are tripartite eukaryotic genotoxins encoded in diverse bacterial and phage genomes. The cdtB subunit is a DNAse that causes eukaryotic cell cycle arrest and apoptosis, and in one context, is associated with resistance against parasitoid wasp infections. Here we report the discovery of functional $c d t B$ copies in the nuclear genomes of insect species from two distantly related insect orders, including fruit flies (Diptera: Drosophilidae) and aphids (Hemiptera: Aphididae). Insect cdtB copies are most closely related to bacteriophage copies, were horizontally transferred to insect genomes $>40$ million years ago and encode a protein that retains ancestral DNase activity. This phage-derived toxin has been domesticated by diverse insects and we hypothesize that it is used as a defensive weapon against parasitoid wasps.
\end{abstract}

One Sentence Summary: We report horizontal transfer of the gene cytolethal distending toxin $B$, which encodes a DNase, into eukaryotic genomes from bacteriophage.

Significance: Cytolethal distending toxins (CDTs) are secreted by diverse pathogenic bacterial species to kill animal cells. The cdtB subunit enters cell nuclei, damaging the DNA and leading to mitotic arrest and apoptosis. In the pea aphid, a bacterial endosymbiont provides protection against wasp attack, possibly via $c d t B$. We discovered that this same endosymbiont-encoded lineage of $c d t B$ was transferred to the genomes of Diptera and Hemiptera species and retains ancestral DNase activity. This is the first report of $c d t B$ outside of bacteria or phages. A toxin that first evolved to kill eukaryotic cells has been co-opted by insects, potentially to their benefit. 


\section{Main Text}

Cytolethal distending toxins (CDTs) are widespread intracellular-acting eukaryotic genotoxins encoded by a gene family restricted to Actinobacteria, Proteobacteria and bacteriophage genomes (1). CDTs are found in diverse pathogens, including Campylobacter jejuni, Escherichia coli, Salmonella enterica, and Yersinia pestis and may be a cause of irritable bowel syndrome (1). CDT holotoxin is an $\mathrm{AB}_{2}$ toxin typically encoded in a three-gene operon $(c d t A, c d t B$, and $c d t C)(2)$ and cdtB is the catalytic subunit necessary for DNase activity $(3,4)$. CdtB nicking leads to DNA damage in eukaryotic cells followed by cell cycle arrest, cellular distention and death (5).

Although cdtB is a eukaryotic genotoxin, in one context it is associated with increased fitness of eukaryotes. Some strains of the bacterium Candidatus Hamiltonella defensa, a secondary endosymbiont of the pea aphid (Acyrthosiphon pisum), are infected with strains of the lysogenic bacteriophage APSE $(6,7)$. APSE-positive $C a$. H defensa strains confer protection from attack by parasitoid braconid wasps that insert eggs into aphids (8). Comparative genomic studies point to $c d t B$, which is encoded in the genome of phage strain APSE-2, as a likely candidate underlying this protective effect (6-8).

We used a sequence similarity-based screen (9) to identify a $c d t B$ homolog as a horizontal gene transfer (HGT) candidate in a de novo genome assembly of the drosophilid fly Scaptomyza flava. To identify $c d t B$ copies in genomes of other eukaryotes, we executed

TBLASTN (10) searches of the NBCI refseq database (which includes all eukaryotes), all NCBI 'Drosophila' genomes, and the genomes of 11 unpublished Hawaiian Drosophila species. We found high-confidence hits to $c d t B$ homologs in the drosophilid species Dr. ananassae, Dr. bipectinata (both in the ananassae subgroup) and Dr. biarmipes, the Hawaiian Dr. primaeva, and 
the aphid species Myzus persicae (Table S1a). We also discovered $c d t B$ orthologs in the transcriptomes of two other species in the ananassae subgroup, Dr.pseudoananassae and Dr. ercepeae (11). We subsequently searched all available AphidBase genomes and found single high-confidence hits to $c d t B$ homologs in the Russian wheat aphid (Diuraphis noxia) and the black cherry aphid (M. cerasi), both in the Macrosiphini (Table S1b).

Putative HGT events can be due to microbial contamination arising from low-quality genome assemblies (12), so we used several methods to address these possibilities (9). First, $c d t B$ was identified on scaffolds in species with high-quality genome assemblies (Table S2). The presence of $c d t B$ was verified by PCR and Sanger sequencing of both genomic and complementary DNA (Table S3; Figure S1). $C d t B$, when present, was found in all transcriptomes except that of $D i$. noxia (Table S1). The transcriptome libraries we searched were enriched for polyadenylated mRNA, suggesting insect $c d t B$ was not due to bacterial contamination since bacteria typically lack 3'- polyA tails (13). Additionally, mRNA sequences of $c d t B$ from all insect species (other than $S$. flava) contain at least three exons separated by intronic splice sites (14), which are rare in bacteria. The absence of $c d t B$ transcripts in Di. noxia, coupled with a frame-shifting deletion and stop codon in the first (and only) predicted exon suggests that this $c d t B$ fragment is a pseudogene in this species.

Phylogenetic conflict between gene tree and species tree topologies provides additional support for HGT (15). To evaluate this and determine the potential source of insect-encoded $c d t B$, we reconstructed a cdtB protein phylogeny using all available sequences $(9)$. Viral, bacterial, and metazoan cdtB sequences were downloaded from the NCBI refseq protein database, aligned and used to create a protein tree (Figure 1, full phylogeny in Figure S2). The cdtB phylogeny reveals that all insect cdtB sequences form a clade with cdtB sequences from 
Ca. H. defensa and APSE-2. A HGT event from an APSE-2 ancestor to eukaryotes is further supported by the case of Dr. bipectinata, in which two $c d t B$ copies are present in tandem array. One of the two $c d t B$ copies in Dr. bipectinata is fused with a homolog of an unrelated AB toxin, apoptosis inducing protein 56, found immediately downstream of $c d t B$ in $C a$. H. defensa. This chimeric $c t d B+$ aip56 sequence is expressed as mRNA in Dr. bipectinata. Synteny between $D r$. bipectinata and $\mathrm{Ca}$. H. defensa suggests the two genes were horizontally transferred together (see Supplementary Text) from a bacterial or phage ancestor prior to the divergence of the extant ananassae spp. subgroup Drosophila species. This hypothesis is supported by the presence of homologous $c d t B+$ aip 56 chimeric sequences in two other ananassae subgroup species, though it has been lost in D. ananassae.

Our data suggest two independent acquisitions of intron-bearing and intronless insect $c d t B$. The cdtB phylogeny resolves two insect-encoded sub-clades, one containing all cdtB sequences encoded by insect-encoded, intron-bearing $c d t B$ copies (Myzus spp., Dr. biarmipes, and ananassae spp.) and the other containing all intron-less insect-encoded cdtB copies (Scaptomyza spp. + D. primaeva), which is in turn sister to the clade containing cdtB from Ca. H. defensa and APSE-2 genomes. Furthermore, an approximately unbiased test forcing monophyly of drosophilid cdtB is slightly worse $(\mathrm{p}=0.059)$ than the recovered cdtB phylogeny, suggesting that the intronless cdtB and the intron-bearing $c d t B$ were independently transferred into insects.

In order to understand the number and timing of horizontal transfer of $c d t B$ in insects, we reconstructed drosophilid and aphid species phylogenies and mapped $c d t B$ evolution on these trees (9). We first constructed a drosophilid species phylogeny including all Drosophila and Scaptomyza genomes scanned for $c d t B$. We performed ancestral state reconstruction (ASR) for 
the origin of $c d t B$ to estimate the number and timing of HGT events across the drosophilid species phylogeny. This analysis, coupled with a clear pattern of conserved synteny within clades, suggests that $c d t B$ was acquired three times in drosophilids: (1) prior to the divergence of the ananassae subgroup (94\% posterior clade probability, or PP) ca. 21 million years ago (mya)

(16), (2) following the split between Dr. biarmipes and Dr. suzukii (98\% PP) ca. $7.3 \pm 2.5$ mya (17), and (3) in an ancestor common to $S$. flava and Dr. primaeva (13\% PP) ca. $24 \pm 7$ mya (18)

(Figure 2A). While the likelihood that $c d t B$ was present in the common ancestor of $D r$.

primaeva and $S$. flava is low based on ASR, synteny suggests that a single HGT event occurred in a common ancestor of these two species. None of the genomes (out of 10 surveyed) from the more recently derived Hawaiian Drosophila species sister to Dr. primaeva were found to encode a $c d t B$ copy. Thus, $c d t B$ was most likely lost prior to the divergence of the picture wing clade, ca. $7 \pm 4$ mya (18). We did not perform ASR in aphids due to limited availability of sequenced aphid genomes. However, $c d t B$ was syntenic in Di. noxia, M. cerasi and M. persicae, distantly related members of the Macrosiphini. We hypothesize that $c d t B$ was horizontally transferred into a common ancestor of these three aphid species (41 \pm 5 mya (19)). While a functional copy was retained in M. persicae and M. cerasi, it was pseudogenized in Di. noxia and lost completely in A. pisum (Figure 2B).

Interestingly, $c d t B$ copies with three exons (Myzus spp., Dr. biarmipes, and ananassae spp.) share identical splice junctions (Figure S3), which indicates either convergent origins of a modular exonic structure or that intron-bearing $c d t B$ copies share a common ancestor and have been transferred horizontally between these distantly related insect lineages after an initial HGT event into one insect (20). HGT within eukaryotes could be mediated by several mechanisms, 
including predaceous mites (21), bracovirus (by parasitoid wasps intermediaries) and helitrons (22). We illustrate hypotheses on the order and timing of $c d t B$ HGT in Figure 2C.

There are many examples of genes derived from prokaryote-to-eukaryote HGT events stably integrating into nuclear genomes, and this process often involves optimizing the transferred genes for expression in eukaryotic cells (23). All insect-encoded $c d t B$ copies exhibit features common to eukaryotic transcription initiation and termination (Figure S4;

Supplementary Text). Additionally, insect $c d t B$ copies have polyadenylated mRNA, 5' and 3' untranslated regions, and introns (except for Scaptomyza spp. + Dr. primaeva), which may modulate eukaryotic transcription/translation $(13,24,25)$. environments $(24,26)$. We evaluated if $c d t B$ shows differential expression patterns throughout development in two drosophilids that represent species with intron-bearing and intronless $c d t B$ (9). Consistent with a potential role in parasitoid resistance, we predicted that $c d t B$ expression would be highest in larvae, the developmental stage most prone to parasitoid attack in drosophilids (27). We used RT-qPCR in larvae, pupae, and adult males and females of S. flava and $D r$. ananassae and found that $c d t B$ expression was indeed highest in larvae of both species (Figure 3).

A critical aspect of cdtB cytotoxicity is its DNase activity, which induces double-strand breaks that can lead to cell cycle arrest, cellular distention and death (5). Residues in cdtB involved in enzyme catalysis, DNA binding, and metal ion binding are critical in causing mitotic arrest in eukaryotic cells and are homologous to those in DNase I. To determine if insectencoded cdtB is a DNase, we aligned cdtB from insect lineages and other bacterial species whose DNase and cytotoxic activity are well-characterized and found that residues necessary for DNase 
activity are highly conserved in all insect copies (Figure 4A, Figure S7). To determine if these conserved residues correspond to DNase activity, we heterologously expressed and purified Histagged cdtB from Dr. ananassae (Figure S5) in E. coli and utilized an agarose gel-based assay to determine its nuclease activity in vitro (9). We incubated Dr. ananassae cdtB (and E. coli cdtB as a positive control) with supercoiled plasmid pGEM-7zf(+) (Promega) at both $28^{\circ} \mathrm{C}$ and $37^{\circ} \mathrm{C}$ for $2 \mathrm{~h}$. Supercoiled plasmid migrates more rapidly through a gel than nicked plasmid, which has greater surface area from relaxed superhelical tension (4). We predicted incubation of supercoiled (sc) plasmid with cdtB would result in a greater proportion of nicked plasmid (open coiled, or oc) isoforms. As expected, purified Dr. ananassae cdtB showed DNase activity in vitro (Figure 4B). Incubation at $28^{\circ} \mathrm{C}$ resulted in higher Dr. ananassae cdtB activity than E. coli and vice versa at $37^{\circ} \mathrm{C}$, which may be a consequence of adaptation to insect and mammalian body temperatures, respectively (see Figure S6).

The maintenance of $c d t B$ in diverse insect genomes for millions of years suggests that it has an adaptive function. One clear possibility is that $c d t B$ plays a role in parasitoid wasp resistance, as it does in the bacterial secondary symbionts of pea aphids $(7,8)$. Given that many drosophilid and aphid species are at high risk of parasitoid wasp attack (27), cdtB may facilitate protection, through DNase activity against the parasitoid wasp egg or larva. In a parasitization assay, $100 \%$ of Dr. ananassae and Dr. biarmipes survived attack by both the generalist Leptopilina heterotoma and specialist L. boulardi (28). It is possible, although speculative, that this unusual level of resistance is facilitated by cdtB.

To our knowledge, this is the first report of the horizontal transfer of $c d t B$ from prokaryotes to eukaryotes. The domestication of $c d t B$ in insects is remarkable given that the toxin originally evolved to destroy, not benefit, eukaryotic cells. Given the wealth of genetic and 
genomic resources available within drosophilids and aphids, horizontally transferred $c d t B$ promises to be an exciting experimentally tractable system in which to explore the biology of a novel eukaryote-adapted toxin, which also has potential in targeting and killing tumor cells in humans (29).

\section{References and Notes}

1. L. Guerra, X. Cortes-Bratti, R. Guidi, T. Frisan, The biology of the cytolethal distending toxins. Toxins 3, 172-190 (2011).

2. M. Lara-Tejero, J. E. Galán, CdtA, CdtB, and CdtC form a tripartite complex that is required for cytolethal distending toxin activity. Infect. Immun. 69, 4358-4365 (2001).

3. M. Lara-Tejero, J. E. Galán, A bacterial toxin that controls cell cycle progression as a Deoxyribonuclease I-like protein. Science 290, 354-357 (2000).

4. C. A. Elwell, L. A. Dreyfus, DNase I homologous residues in CdtB are critical for cytolethal distending toxin-mediated cell cycle arrest. Mol. Microbiol. 37, 952-963 (2000).

5. R. N. Jinadasa, S. E. Bloom, R. S. Weiss, G. E. Duhamel, Cytolethal distending toxin: a conserved bacterial genotoxin that blocks cell cycle progression, leading to apoptosis of a broad range of mammalian cell lineages. Microbiology 157, 1851-1875 (2011).

6. N. A. Moran, P. H. Degnan, S. R. Santos, H. E. Dunbar, H. Ochman, The players in a mutualistic symbiosis: insects, bacteria, viruses, and virulence genes. Proc. Natl. Acad. Sci. 102, 16919-16926 (2005).

7. P. H. Degnan, N. A. Moran, Diverse phage-encoded toxins in a protective insect endosymbiont. Appl. Environ. Microbiol. 74, 6782-6791 (2008). 
8. K. M. Oliver, P. H. Degnan, M. S. Hunter, N. A. Moran, Bacteriophages encode factors required for protection in a symbiotic mutualism. Science 325, 992-994 (2009).

9. Materials and methods are available as supplementary materials.

10. S. F. Altschul, T. L. Madden, A. A. Schäffer, J. Zhang, Z. Zhang, W. Miller, D. J. Lipman, Gapped BLAST and PSI-BLAST: a new generation of protein database search programs. Nucleic Acids Res. 25, 3389-3402 (1997).

11. S. Signor, T. Seher, A. Kopp, Genomic resources for multiple species in the Drosophila ananassae species group. Fly 7, 47-57 (2013).

12. G. Koutsovoulos, S. Kumar, D. R. Laetsch, L. Stevens, J. Daub, C. Conlon, H. Maroon, F. Thomas, A. A. Aboobaker, M. Blaxter. No evidence for extensive horizontal gene transfer in the genome of the tardigrade Hypsibius dujardini. Proc. Natl. Acad. Sci. 113, 50535058 (2016).

13. M. Dreyfus, P. Régnier, The poly(A) tail of mRNAs: Bodyguard in eukaryotes, scavenger in bacteria. Cell 111, 611-613 (2002).

14. S. Kitamura-Abe, H. Itoh, T. Washio, A. Tsutsumi, M. Tomita, Characterization of the splice sites in GT-AG and GC-AG introns in higher eukaryotes using full-length cDNAs. J. Bioinform. Comput. Biol. 2, 309-331 (2004).

15. E. A. Gladyshev, M. Meselson, I. R. Arkhipova, Massive horizontal gene transfer in bdelloid rotifers. Science 320, 1210-1213 (2008).

16. M. Nozawa, M. Kumagai, T. Aotsuka, K. Tamura, Unusual evolution of interspersed repeat sequences in the Drosophila ananassae subgroup. Mol. Biol. Evol. 23, 981-987 (2006).

17. L. Ometto, A. Cestaro, S. Ramasamy, A. Grassi, S. Revadi, S. Siozios, M. Moretto, P. 
Fontana, C. Varotto, D. Pisani, T. Dekker, N. Wrobrei, R. Viola, I. Pertot, D. Cavalieri, M. Blaxter, G. Anfora, O. Rota-Stabelli, Linking genomics and ecology to investigate the complex evolution of an invasive Drosophila pest. Genome Biol. Evol. 5, 745-757 (2013).

18. K. N. Magnacca, D. K. Price, Rapid adaptive radiation and host plant conservation in the Hawaiian picture wing Drosophila (Diptera: Drosophilidae). Mol. Phylogenet. Evol. 92, 226-242 (2015).

19. Z. Ren, A. J. Harris, R. B. Dikow, E. Ma, Y. Zhong, J. Wen, Another look at the phylogenetic relationships and intercontinental biogeography of eastern Asian - North American Rhus gall aphids (Hemiptera: Aphididae: Eriosomatinae): Evidence from mitogenome sequences via genome skimming. Mol. Phylogenet. Evol. 117, 102-110 (2017).

20. M. Long, E. Betrán, K. Thornton, W. Wang, The origin of new genes: Glimpses from the young and old. Nat. Rev. Genet. 4, 865-875 (2003).

21. M. A. Houck, J. B. Clark, K. R. Peterson, M. G. Kidwell, Possible horizontal transfer of Drosophila genes by the mite Proctolaelaps regalis. Science 253, 1125-1128 (1991).

22. L. Gasmi, H. Boulain, J. Gauthier, A. Hua-Van, K. Musset, A. K. Jakubowska, J. Aury, A. Volkoff, E. Huguet, S. Herrero, J. Drezen, Recurrent domestication by Lepidoptera of genes from their parasites mediated by bracoviruses. PLoS Genet. 11, 1-32 (2015).

23. Y. Sasakura, Y. Ogura, N. Treen, R. Yokomori, S. Park, K. Nakai, H. Saiga, T. Sakuma, T. Yamamoto, S. Fujiwara, K. Yoshida, Transcriptional regulation of a horizontally transferred gene from bacterium to chordate. Proc. R. Soc. B. 283, 20161712 (2016).

24. F. Husnik, J. P. McCutcheon, Functional horizontal gene transfer from bacteria to eukaryotes. Nat. Rev. Microbiol. 16, 67-79 (2017). 
25. L. Barrett, S. Fletcher, S. Wilton, Untranslated Gene Regions and Other Non-coding Elements (Springer, Basel, 2013).

26. N. Wybouw, Y. Pauchet, D. G. Heckel, T. Van Leeuwen, Horizontal gene transfer contributes to the evolution of arthropod herbivory. Genome Biol. Evol. 8, 1785-1801 (2016).

27. Y. Carton, M. Poirié, A. J. Nappi, Insect immune resistance to parasitoids. Insect Sci. 15, 67-87 (2008).

28. T. A. Schlenke, J. Morales, S. Govind, A. G. Clark, Contrasting infection strategies in generalist and specialist wasp parasitoids of Drosophila melanogaster. PLoS Pathog. 3, 1486-1501 (2007).

29. C. Bachran, R. Hasikova, C. E. Leysath, I. Sastalla, Y. Zhang, R. J. Fattah, S. Liu, S. H. Leppla, Cytolethal distending toxin B as a cell-killing component of tumor-targeted anthrax toxin fusion proteins. Cell Death Dis. 5, e1003 (2014).

30. H. Kim, S. Lee, Y. Jang, Macroevolutionary patterns in the Aphidini aphids (Hemiptera: Aphididae): diversification, host association, and biogeographic origins. PLoS One. 6, e24749 (2011)

31. B. N. Singh, Species and genetic diversity in the genus Drosophila inhabiting the Indian subcontinent. J. Genet. 94, 351-361 (2015).

32. H. F. van Emden, V. F. Eastop, R. D. Hughes, M. J. Way, The ecology of Myzus persicae. Annu. Rev. Entomol. 14, 197-270 (1969). 


\section{Acknowledgments:}

We thank Dr. Chris Jeans and Brooks Bond-Watts for their preparation of purified cdtB.

Timothy O’Connor provided bioinformatics advice, Raoul O. Martin provided biochemistry advice, Julianne N. Pelaez assisted in phylogenetic reconstruction, and Anthony T. Iavarone performed mass spectrometry analysis. Coco Verster provided field assistance in acquiring specimens. Dr. Artyom Kopp and Dr. Doris Bachtrog provided Drosophila specimens. The Myzus persicae transcriptome assembly was provided by Alex Wilson and Honglin Feng. Dr. Nancy Moran ran BLAST searches of unpublished aphid genomes that corroborated our conclusions from this study. Dr. Naomi E. Pierce and Dr. Frederick M. Ausubel provided early support for obtaining a genome sequence from S. flava. Funding: KIV was supported by a National Science Foundation Graduate Research Fellowship and grants from Sigma Xi (University of California - Berkeley chapter) and the Animal Behavior Society. RPD was supported by the Miller Institute for Basic Research in Science at the University of California, Berkeley. Research was supported by the National Institute of General Medical Science of the National Institutes of Health award number R35GM119816 to NKW. Author contributions: KIV, ADG, MK, RPD, and NKW were involved in conceptualization of the project. KIV, JHW, RPD, MK, ZMA, EA, DKP and NKW conducted the investigations. KIV, RPD and NKW wrote the paper. All authors edited and approved the manuscript. Conflict of interest: KIV, ADG and NKW are inventors on a pending patent application related to this work, entitled "Cytolethal distending toxin B from insects for human cancer treatment". Data and materials availability: $C d t B$ sequences from Scaptomyza species and D. primaeva were deposited to NCBI GenBank 
bioRxiv preprint doi: https://doi.org/10.1101/544197; this version posted February 9, 2019. The copyright holder for this preprint (which was not certified by peer review) is the author/funder, who has granted bioRxiv a license to display the preprint in perpetuity. It is made available under aCC-BY-NC-ND 4.0 International license.

under accession numbers MH884655-MH884659. CdtB codon-optimized oligos used for nuclease assays were deposited under GenBank accessions MH891796-MH891799.

\title{
Supplementary Materials:
}

\author{
Materials and Methods
}

Figures S1-S8

Tables S1-S9

References (33-105) 

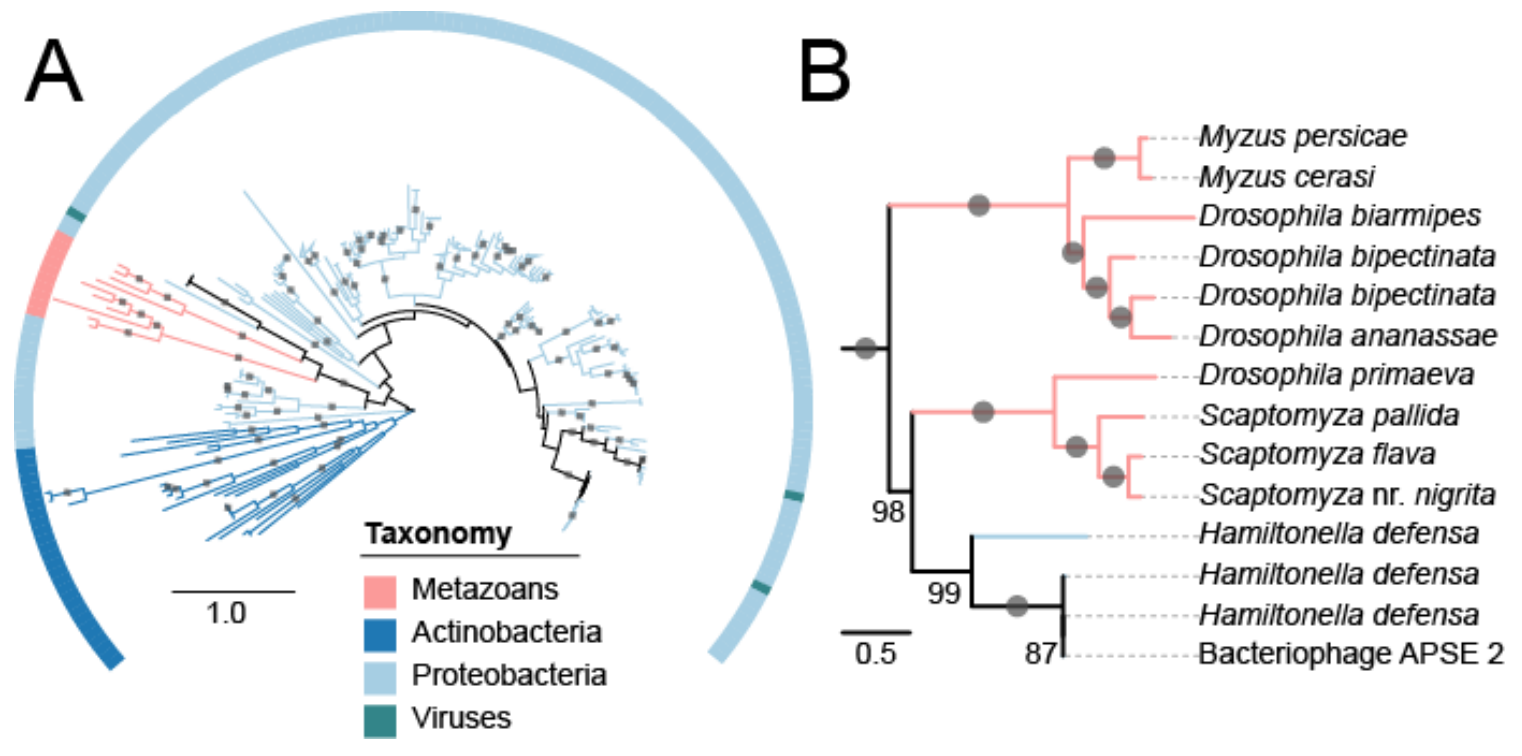

Fig. 1. CdtB protein phylogeny indicates HGT into insects from bacteria.

(A) ML phylogeny of cdtB from across the tree of life. Tree is midpoint rooted and branches

with $100 \%$ bootstrap support are indicated by grey circles. Four clades consisting of highly

similar sequences from Proteobacteria were collapsed for clarity. The full phylogeny is available

in Fig. S2. (B) Detailed view of insect cdtB clades. Numbers below branches indicate percent

bootstrap support when $<100$. 
bioRxiv preprint doi: https://doi.org/10.1101/544197; this version posted February 9, 2019. The copyright holder for this preprint (which was not certified by peer review) is the author/funder, who has granted bioRxiv a license to display the preprint in perpetuity. It is made available under aCC-BY-NC-ND 4.0 International license.
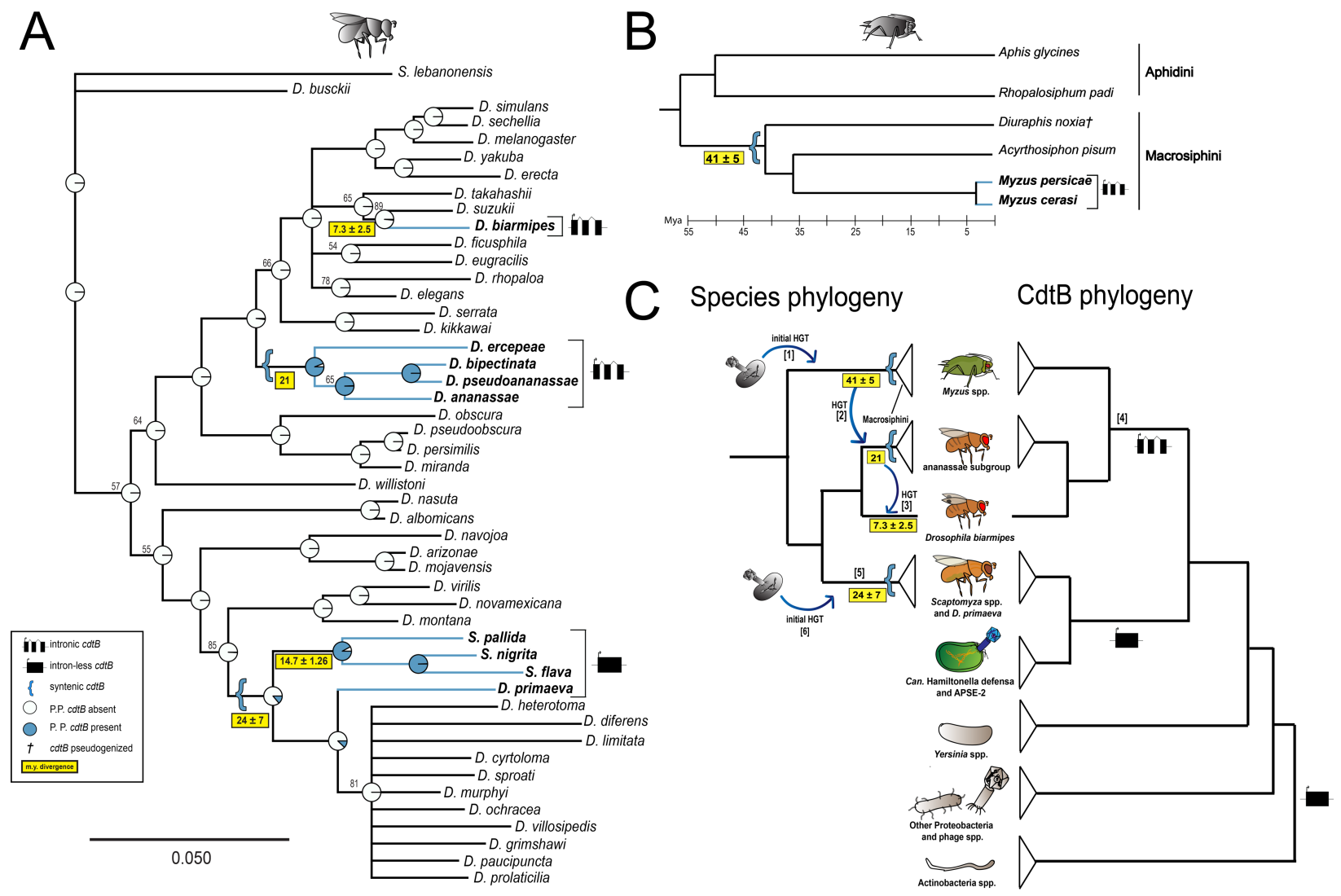


\section{Fig. 2. Species phylogenies show $c d t B$ was transferred into, and possibly between, genomes}

\section{of distant insect lineages.}

A. ML phylogeny of drosophilid species. Node labels indicate bootstraps if $<90 \%$ or are collapsed to polytomies if $<50 \%$. ASR shows posterior probability (P.P.) of $c d t B$ at nodes. B. Phylogeny of Aphidinae species. Branch lengths drawn approximately to scale using divergence dates from $(19,30)$. C. Simplified paired cdtB and species phylogenies. Blue arrows suggest possible HGT directions and bracketed numbers are described here. Possible initial prokaryoteeukaryote HGTs are [1,6]. We hypothesize an initial HGT of $c d t B$ from bacteria or phage integrated into an aphid nuclear genome [1] and was lost or pseudogenized in some aphid lineages (2B). We then posit an inter-ordinal transfer [2] from a Myzus spp. ancestor to an ananassae subgroup spp. ancestor, followed by inter-specific transfer [3] to a D. biarmipes ancestor. This transfer sequence is supported by subclade ages, conserved intron splice sites in [4], and the regional co-occurrence of these subclades $(31,32)$. However, conserved exon structure in [4] could also arise from convergence. CdtB in [5] could have evolved independently, or was derived from the same HTG as [4] but failed to acquire introns. 


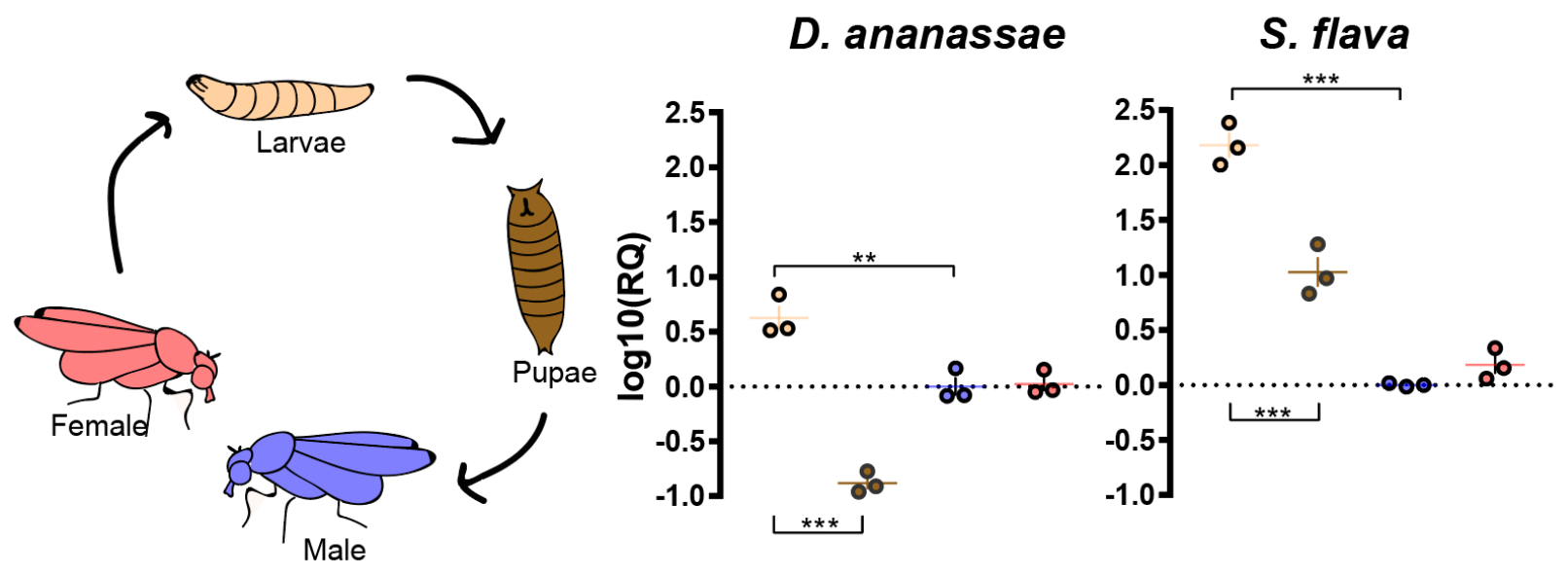

Fig. 3. CdtB is expressed most highly in the Drosophila larval stage.

Fold changes in expression of $c d t B$ in two representative insect lineages (Dr. ananassae and $S$.

flava) across development. Colors correspond to developmental stages in the left panel. Fold change is standardized against $r p l 32$ mRNA expression in males. Each dot represents one biological replicate. $P<0.005^{* *}, P<0.0001^{* * *}$. All pairwise comparisons (except those between males and females) are significantly different, but are not marked for simplicity. 

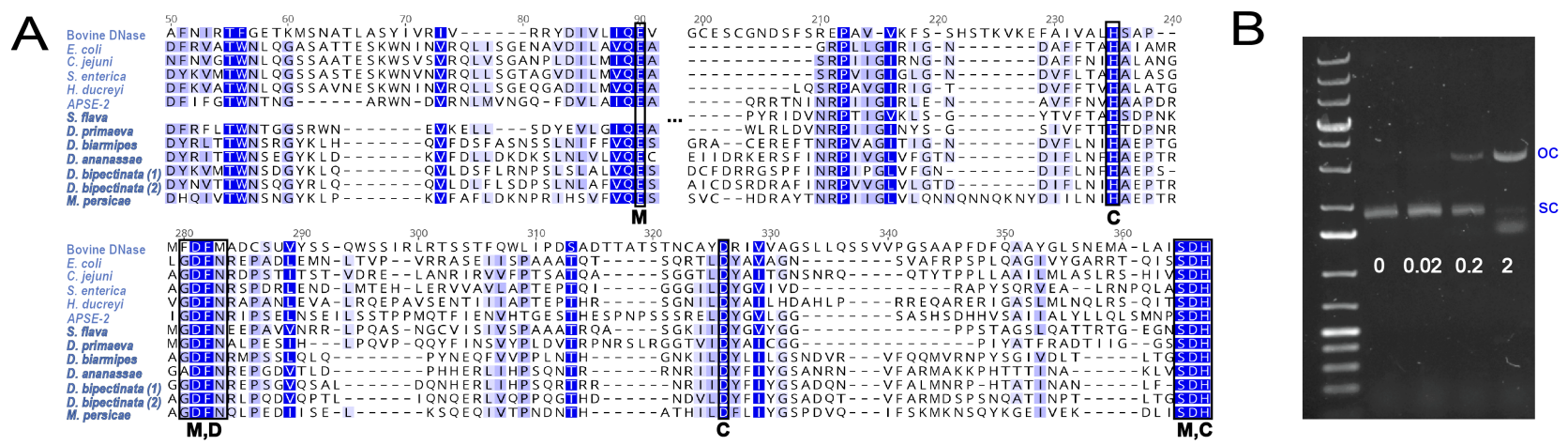

Fig. 4. Critical DNase residues are conserved in insect-encoded cdtB and confer DNase activity in vitro.

A. MUSCLE aligned amino acid sequence of DNase I and cdtB across taxa. Boxed residues are necessary for DNase activity of cdtB. Blue scale corresponds to similarity under the Blosum62 scoring matrix. Numbers correspond to alignment residue. Breaks in alignment are indicated by brackets. Species names in bold are eukaryotic. $\mathrm{M}=$ metal-ion binding residues, $\mathrm{C}=$ catalytic residues, $\mathrm{D}=\mathrm{DNA}$ contact residues (4). B. Plasmid degradation following exposure to variable 10 quantities (in $\mu \mathrm{g}$ ) of cdtB from Dr. ananassae over $2 \mathrm{hrs.} 0.8 \%$ agarose $1 \mathrm{X}$ TBE gels were stained with $0.01 \%$ SYBR ${ }^{\mathrm{TM}}$ Safe. $\mathrm{OC}=$ open-coil isoform, $\mathrm{SC}=$ supercoiled isoform. 


\section{Supplementary Materials for}

Kirsten I. Verster", Jennifer H. Wisecaver, Rebecca P. Duncan, Marianna Karageorgi, Andrew D. Gloss, Ellie Armstrong, Donald K. Price, Aruna R. Menon, Zainab M. Ali, Noah K. Whiteman*

\section{This PDF file includes:}

Materials and Methods

Supplementary Text

Figs. S1 to S5

Tables S1 to S8

References (30-94) 


\section{Materials and Methods}

Materials and methods are described in the order they appear in the main text.

Initial detection of horizontally transferred protein coding genes in insects: Scaptomyza flava From the annotated genome assembly of S. flava (GenBank Accession RKRM00000000.1), all predicted protein sequences were queried against a local copy of the NCBI refseq protein database (downloaded May 5, 2017) using phmmer, in the HMMER3 software suite (33), with acceleration parameters --F1 1e-5 --F2 1e-7 --F3 1e-10. A custom perl script sorted the phmmer results based on the normalized bitscore $(n b s)$, where $n b s$ was calculated as the bitscore of the single best-scoring domain in the hit sequence divided by the best bitscore possible for the query sequence (i.e., the bitscore of the query aligned to itself). The top $\leq 10,000$ hits were retained for further analysis, saving no more than three sequences per unique NCBI Taxonomy ID.

The alien index score $(A I)$ was calculated for each query protein (modified from Gladyshev et al., 2008). The $A I$ is given by the formula: $\mathrm{AI}=\mathrm{nbsO}-\mathrm{nbsM}$, where $n b s O$ is the normalized bitscore of the best hit to a non-metazoan species, $n b s M$ is the normalized bitscore of the best hit to a metazoan (skipping all hits to the Drosophilini tribe NCBI:txid46877). AI can range from 1 to -1 and is $>0$ if the gene has a better hit to a non-metazoan, which is suggestive of either HGT or contamination in the assembly. To reduce the risk of contamination, genes were considered potential HGT candidates if they were assembled on scaffolds with $\geq 5$ protein coding genes and the average $A I$ of the scaffold was $<0$.

Phylogenetic trees of protein sequences were constructed for all potential HGT candidates with $A I>0$. Full-length proteins corresponding to the top 200 hits (E-value $<1 \times 10^{-}$ $\left.{ }^{3}\right)$ to each query sequence were extracted from the local database using esl-sfetch (33). Protein sequences were aligned with MAFFT v7.310 using the E-INS-i strategy and the BLOSUM30 amino acid scoring matrix (34) and trimmed with trimAL v1.4.rev15 using its gappyout strategy (35). Proteins with trimmed alignments $<150$ amino acids in length were excluded. The topologies of the remaining genes were inferred using maximum likelihood as implemented in IQ-TREE v1.5.4 (36) using an empirically determined substitution model and rapid bootstrapping (1000 replications). The phylogenies were midpoint rooted and branches with local support $<95$ were collapsed using the ape and phangorn $\mathrm{R}$ packages $(37,38)$. Phylogenies were visualized using ITOL version 3.0 (39) and inspected manually to identify phylogenetically supported HGT candidate proteins. The cdtB phylogeny was the only one that passed this manual inspection.

$35 \quad$ Identification of $c d t B$ in aphid genomes and transcriptomes An initial TBLASTN search using $S$. flava cdtB against NCBI nr resulted in hits to Myzus persicae, an aphid species, as well as other drosophilids (discussed below). We therefore further searched for $c d t B$ in genomes and transcriptomes from representatives of Aphididae. Aphids were sampled based on availability of published or unpublished genomic resources, and included 11 species from three tribes and three subfamilies. Representatives from the subfamily Eriosomatinae, which is sister to the rest of aphids (40) were included in our sampling: Pemphigus obesinymphae and Pemphigus populicaulis (Subfamily: Eriosomatinae, Tribe: Pemphiginae), Tamalia coweni and Tamalia inquilinus (Subfamily: Tamaliinae), Myzus persicae, Myzus cerasi, Diuraphis noxia and Acyrthosiphon pisum (Subfamily: Aphidinae, Tribe: Macrosiphini), and Aphis glycines, Aphis nerii, and Rhopalosiphum padi (Subfamily: Aphidinae, Tribe: Aphidini). Genomes were sampled from M. persicae (41), M. cerasi (available on 
aphidbase.com), A. pisum (42), Di. noxia (43), Ap. glycines (available on aphidbase.com), and $R$. padi (available on aphidbase.com). We sampled published transcriptomes from the remaining aphid species (44-47).

We searched genome or transcriptome assemblies for the presence of $c d t B$ with TBLASTN searches using two different cdtB proteins as the query: cdtB from M. persicae (XP_022163116.1) and cdtB from the Candidatus Hamiltonella defensa phage APSE-2 (C4K6T7), since it is infects aphid species (48). CdtB full or partial hits were only found in three aphids with genome sequences ( $M$. persicae, $M$. cerasi, and Di. noxia), so to assess if $c d t B$ was expressed in those species, we searched transcriptome assemblies for each species with TBLASTN searches using the same query proteins (Table S1c). For $M$. persicae, we used the assembly from the previously published transcriptome (49), and for M. cerasi and Di. noxia we conducted de novo assemblies from previously published RNAseq data. We downloaded raw RNAseq reads for M. cerasi (BioProject PRJEB9912, runs ERR983165 (head), ERR983166 (head), ERR983167 (head), ERR983168 (whole body), ERR983169 (whole body), ERR983170 (whole body) (PRJEB9912) and Di. noxia (BioProject PRJNA233413, runs SRR1999270 (whole body) and SRR1999279 (whole body) (43) from the Sequence Read Archive on GenBank. All runs for each species were combined into a reference transcriptome in Trinity v. 2.4.0 (50) using the built in Trimommatic pipeline for quality trimming (default parameters) and in silico normalization.

Demonstrating $c d t B$ is encoded in the nuclear genome of drosophilid species

Analysis of possible contamination by coverage depth analysis in $\mathrm{S}$. flava.

For $S$. flava, we aligned long PacBio reads to the genome via Burrows-Wheelers alignment (51) to search for unusual coverage depth relative to neighboring genes, which can be a reflection of contamination (12). The region containing $S$. flava $c d t B$ did not exhibit unusual coverage depth (Grubbs' test, $\mathrm{p}>0.05$ ) (Table S4).

\section{$P C R$ and $R T-P C R$ reaction conditions.}

$30 \quad$ PCR reaction conditions were composed of: $4.2 \mu \mathrm{L}$ nuclease-free water, $7.5 \mu \mathrm{L}$ Failsafe Premix E (Epicentre), $1.2 \mu \mathrm{L}$ each of $\mathrm{F}$ and R primers (IDT), $0.8 \mu \mathrm{L}$ DNA, and $0.12 \mu \mathrm{L}$ of Taq polymerase (New England Biolabs). Thermal cycler settings were: $5 \mathrm{~m}$ at $95^{\circ} \mathrm{C}$ and 30 cycles of $95^{\circ} \mathrm{C}$ for $30 \mathrm{~s}$, Ta for $30 \mathrm{~s}$, and $68^{\circ} \mathrm{C}$ for $30 \mathrm{~s}$, followed by $5 \mathrm{~m}$ of extension at $68^{\circ} \mathrm{C}$. The exception to this was with $S$. flava Intergenic PCR amplification. PCR reaction conditions were composed of: $12 \mu \mathrm{L}$ nuclease-free water, $4 \mu \mathrm{L} 5 \mathrm{X}$ Phusion HF buffer, $0.4 \mu \mathrm{L} 10 \mathrm{mM}$ dNTPs, 1 $\mu \mathrm{L} 10 \mu \mathrm{M}$ Intergenic F and R primers (IDT), respectively, $0.6 \mu \mathrm{L}$ DMSO, $0.2 \mu \mathrm{L}$ Phusion DNA polymerase (New England Biolabs), and $0.8 \mu \mathrm{L}$ template gDNA. Thermal cycler settings were: $30 \mathrm{~s}$ at $98^{\circ} \mathrm{C}$ and 30 cycles of $98^{\circ} \mathrm{C}$ for $10 \mathrm{~s}, 64.1^{\circ} \mathrm{C}$ for $30 \mathrm{~s}, 72^{\circ} \mathrm{C}$ for $2 \mathrm{~m} 40 \mathrm{~s}$, followed by 10 $\mathrm{m}$ extension at $72^{\circ} \mathrm{C}$.

$401 \%$ agarose $1 \mathrm{X}$ TBE gels were prepared with Apex Agarose in $1 \mathrm{X}$ TBE buffer with $1 \mu \mathrm{L}$ SYBR ${ }^{\text {TM }}$ Safe staining gel per $10 \mathrm{~mL}$ of gel solution. $4 \mu \mathrm{L}$ PCR product was mixed with $1 \mu \mathrm{L}$ ThermoScientific 6X Loading Dye and run on 1\% gels in Owl ${ }^{\text {TM }}$ EasyCast ${ }^{\text {TM }}$ B1 Mini Gel Electrophoresis System rigs at $120 \mathrm{~V}$ for $30 \mathrm{~m} .5 \mu \mathrm{L}$ of ladder was used (O'Gene Ruler 100 bp or O'Gene Ruler 1kb). Gels were visualized using AlphaImager TM Gel Imaging System (Alpha Innotech). PCR amplicons were Sanger sequenced in both directions at the UC Berkeley DNA 
Sequencing Facility using ABI dye terminator chemistry. Relevant gel images and primers are shown in Figure S1 and Table S3.

CdtB phylogeny reconstruction and topology test

All insect-encoded cdtB protein sequences translated from nucleotides were queried against an updated local copy of the NCBI refseq protein database (downloaded August 1, 2018) using phmmer (33) and default parameters, saving no more than one sequence per unique NCBI Taxonomy ID. Full-length proteins were extracted from the local database using esl-sfetch (33), and results from each insect cdtB search were combined to yield a final cdtB sequence set for phylogenetic analysis. Sequences were aligned with MAFFT v7.310 using the L-INS-i strategy and the BLOSUM30 amino acid scoring matrix (34). A total of 15 proteobacterial hits were excluded due to poor alignment and the remaining sequences were trimmed to include only the conserved cdtB domain. MAFFT was then repeated. The topology of cdtB was inferred using maximum likelihood as implemented in IQ-TREE v1.5.4 (36) and RAxML v8.2.9 (52) using empirically determined substitution models. Ten independent searches with different starting trees were carried out using each program as recommended by (53). The likelihood scores of all trees were re-calculated using RAxML and the tree with the highest likelihood was selected as the best cdtB phylogeny. Lastly, 1000 non-parametric bootstrap replicates were performed in IQTREE on the final phylogeny (Figure S2).

Constrained phylogenetic trees in which the insect-encoded cdtB were forced to be monophyletic were also constructed. As with the best tree, ten independent searches with different starting trees were carried out using RAxML and IQ-TREE, and the tree with the highest likelihood given the constraint was selected as the constrained cdtB tree. The best and constrained trees were then compared in CONSEL v1.2 (54) using the approximately unbiased (AU) test (55).

\section{Ancestral state reconstruction of $c d t B$ in Drosophila}

To construct a drosophilid species tree, DNA sequences from adh, marf, COI, COII, 16s, cytb, $g p d h, n d 1$, and $n d 2$ (see Table $\mathbf{S 5}$ for sources of phylogenetically informative genes) were aligned individually using default settings in MUSCLE (56) as implemented in Geneious (57). Alignments were visually inspected, manually trimmed and then concatenated. The final alignment included 48 species with 7479 nucleotide sites. The concatenated alignment was used to infer a drosophilid species phylogeny using maximum likelihood with the TN93 (58) model of nucleotide substitution in MEGA v10.0.4. The tree with the highest log likelihood (-60735.94) is shown with Scaptodrosophila lebanonensis as the outgroup. Branch lengths are drawn to scale and are measured in number of substitutions per site. Bootstraps values are shown $(\mathrm{n}=500)$ and those less than $50 \%$ were collapsed into polytomies. Maximum-likelihood ancestral state reconstruction of $c d t B$ HGT occurrence was performed using the "rerooting Method" function under an equal-rates model in phytools (59) in R v. 1.1.456 (60).

Expression of $c d t B$ throughout development

Sample preparation and collection.

Ca. 100 male and female Dr. ananassae (13-17 days old, the optimal egg-laying age as determined by a pilot study) were left in small embryo collection cages (Genesee Scientific, \#59100) for 6 hours with $60 \times 15 \mathrm{~mm}$ Falcon polystyrene petri dishes filled with $3 \%$ agar in organic apple juice with a dab of Fleischmann's active dry yeast paste. After egg-laying, eggs were 
cleaned and isolated in Corning Netwells inserts (\#3477) and transferred onto $100 \times 15 \mathrm{~mm}$ petri dishes with Nutri-Fly media (Genesee Scientific \#66-112) prepared using standard protocols. For S. flava, $>25$ male and females (5-7 days old) were staged as above except petri dishes were filled with 3\% agar and Arrowhead water with 5-9 Col-0 Arabidopsis thaliana leaves from adult plants submerged in the agar. For each species, we collected L2 (assessed by FBdv:00005338) (L), P-2 (assessed by (61)) (P), and virgin females (F) and males (M). For Dr. ananassae L, P, F and $\mathrm{M}$, we collected 10, 5, 5, and 5 individuals, respectively, per replicate. For $S$. flava, we collected 4, 3, 3, and 3 individuals, respectively, per replicate. Samples were submerged in Ringer's solution prior to collection. Each species and developmental stage had three replicates. Experiments occurred at $25^{\circ} \mathrm{C}$ under $14 \mathrm{~h}$ light: $10 \mathrm{~h}$ dark cycles.

\section{RNA extraction and $c D N A$ synthesis.}

Samples were washed in Ringer's solution again prior to RNA extraction. We performed RNA extraction using the Promega ReliaPrep RNA Tissue MiniPrep System following guidelines of protocol for samples $<5 \mathrm{mg}$. Final elution volume was $10 \mu \mathrm{L}$ in nuclease-free water. RNA concentration and purity were quantified using NanoDrop ND-1000 (Thermo Fisher). We performed cDNA synthesis following standard protocols with the ProtoScript cDNA synthesis kit (NEB) using $1 \mu \mathrm{g}$ of RNA for each sample. Synthesis of cDNA was confirmed via Qubit Fluorometer 2.0 (Invitrogen) using dsDNA HS Assay Kit (Thermo Fisher).

$R T-q P C R$ primer design.

RT-qPCR primers for $c d t B$ and $r p l 32$ were designed using GenScript Real- time PCR (TaqMan) Primer Design tool (https://www.genscript.com/tools/real-time-pcr-tagman-primer-design-tool). Default primer settings were used with selection for primers. Efficiencies were determined via standard curves. Four serial 1:10 dilutions were prepared starting at $20 \mathrm{ng}$, two technical replicates and two controls with nuclease-free water in lieu of template cDNA. Melt curves showed all primer sets had high specificity. Since in most cases primers could not be designed to span exon/exon boundaries (with the exception of $S$. flava rpl32), we confirmed there was no genomic DNA contamination by loading the RNA product in a $1 \%$ agarose $1 \mathrm{X}$ TBE gel and by conducting RT-PCR of a no RT control and running out products on 1\% agarose 1X TBE gels. Primer sequences, efficiencies, and concentrations used are shown in Table S6.

\section{RT-qPCR cycling conditions.}

RT-qPCR reactions were run on StepOne ${ }^{T M}$ Real-Time PCR System (ThermoFisher Scientific). Reaction volumes were as follows: $10 \mu \mathrm{L} 2 \mathrm{X}$ DyNAmo HS SYBR Green qPCR Kit, $0.15 \mu 1$ ROX Passive Reference Dye, $0.5 \mu \mathrm{l}$ of $40 \mu \mathrm{M}$ forward and reverse primers, and $20 \mathrm{ng}$ cDNA to a total reaction volume of $20 \mu \mathrm{l}$. All run cycles included initial 10 minute denaturation at $95^{\circ} \mathrm{C}, 40$ cycles of: $95^{\circ} \mathrm{C}$ for $15 \mathrm{~s}, 60^{\circ} \mathrm{C}$ for $1 \mathrm{~m}$, followed by a melt curve ramp from $60^{\circ} \mathrm{C}$ to $95^{\circ} \mathrm{C}$ where data was collected every $+3^{\circ} \mathrm{C}$. Nuclease-free water was used for no template controls.

Data analysis.

Relative quantification was calculated according to the Pfaffl model (62) using primer efficiencies described in the supplement. Multiple comparisons were analyzed by two-tailed ttests and visualized in GraphPad Prism v7.04 (GraphPad Software, San Diego, USA). 
Evaluating insect cdtB DNase activity

MUSCLE alignment of cdtB residues across taxa.

DNase and cdtB amino acid residues were found from the following sources: Bovine DNase

P00639, E. coli Q46669, C. jejuni A0A0E1ZJ81, S. enterica G5MJJ6, H. ducreyi G1UB80, APSE-2 C4K6T7, Dr. biarmipes XP_016950904.1, Dr. ananassae XP_014760894.1, Dr. bipectinata (1) XP_017099970.1,Dr. bipectinata (2) XP_017099943.1, M. persicae XP_022163116.1. S. flava and Dr. primaeva sequences were translated from CDS in MH88465 and MH884659, respectively. Sequences were aligned using MUSCLE (56) using a maximum number of 50 iterations and visualized in Geneious (57) with a custom blue-scale color scheme based on the Blosum62 scoring matrix (with a threshold of 1). Thus, darker blue colors correspond to higher similarity of a residue in the alignment.

Cloning cdtB.

$C d t B$ oligos from $E$. coli, Dr. ananassae, S. flava and $C a$. H. defensa were codon-optimized for E. coli expression and synthesized by GenScript Codon Optimization Services (deposited under GenBank accession \#s MH891796-MH891799). CdtB was cloned into the pET His6 TEV vector 2B-T (a gift from Scott Gradia, Addgene plasmid \#29666) using sequence and ligationindependent cloning (SLIC) (63).

Phobius (64) predicted signal peptides in cdtB from Dr. ananassae and E. coli and a transmembrane domain in $\mathrm{Ca}$. H. defensa cdtB. In order to facilitate protein expression and purification, these domains were removed by amplifying GenScript oligos with the following SLIC-compatible primers: E. coli F: 5'-

TACTTCCAATCCAATgcaGACCTGACCGATTTTCGTGTGG-3'; E. coli R: 5'ACGACGGCTAACACCAACCGGATAGTGATCGCTGCTCATCTGGGTACGACGCGCAC CATAAACAATGCCCGCTTGCAGC-3'; Dr. ananassae F: 5'-

TACTTCCAATCCAATgcaGACGTTACCGATTACCGTATTACCAC-3'; Dr. ananassae R: 5'-TTATCCACTTCCAATgttattaGCCACGCGGCGCC-3'; Ca. H. defensa F: 5' TACTTCCAATCCAATgcaAGCCAAAGCCACAACCACAAC-3'; Ca. H. defensa R: 5' TTATCCACTTCCAATgttattaGTTAAATTTAACCGGCTTGTGGTCG-3'. For S. flava, SLIC was performed using the following primers: S. flava F: 5'-

TACTTCCAATCCAATgcaATGGCGATCATTACCCGTGAGC-3'; S. flava R: 5'TTATCCACTTCCAATgttattaGCCGTTCATCGGCGCC-3'. CdtB was cloned following University of California - Berkeley QB3 SLIC protocols (available at: http://qb3.berkeley.edu/macrolab/lic-cloning-protocol/ [accessed March 28, 2018]).

CdtB expression and purification.

Clones were transformed into Rosetta ${ }^{\mathrm{TM}}$ 2(DE3)pLysS competent cells (Novagen) following manufacturer protocols. Freshly transformed cells were grown in $2 \mathrm{xYT}$ medium at $37^{\circ} \mathrm{C}$ to an $40 \mathrm{OD}_{600}$ of approximately 0.6 , at which point the incubation temperature was lowered to $16^{\circ} \mathrm{C}$. After $20 \mathrm{~m}$ growth at this temperature, IPTG was added to a final concentration of $0.5 \mathrm{mM}$. Cells were harvested by centrifugation after overnight growth at $16^{\circ} \mathrm{C}$, resuspended in Nickel Buffer A (25 mM HEPES pH 7.5, $400 \mathrm{mM} \mathrm{NaCl}, 5 \%$ glycerol, $20 \mathrm{mM}$ imidazole), then frozen at $-80^{\circ} \mathrm{C}$. Proteins were purified by Ni affinity chromatography, followed by removal of the His-tag with TEV protease, and size-exclusion chromatography. 
After removal of the His-tag from the E. coli cdtB, a subtractive Ni affinity step was used to separate the untagged protein from the TEV protease and other contaminant proteins. The untagged protein was concentrated and loaded onto a HiPrep 16/60 Sephacryl S-200 HR sizeexclusion column equilibrated in $25 \mathrm{mM}$ HEPES-NaOH pH 7.5, $400 \mathrm{mM} \mathrm{NaCl}, 10 \%$ glycerol. Fractions containing cdtB were pooled and concentrated, assayed by UV absorption, and frozen in aliquots at $-80^{\circ} \mathrm{C}$.

The His-tag could not be removed from Dr. ananassae cdtB by TEV protease, and so the His-tagged protein was further purified by size-exclusion chromatography on a HiPrep 16/60 Sephacryl S-300 HR column equilibrated in $25 \mathrm{mM}$ Tris- $\mathrm{HCl} \mathrm{pH}$ 8.0, $200 \mathrm{mM} \mathrm{NaCl}, 10 \%$ glycerol, $2 \mathrm{mM}$ EDTA, $5 \mathrm{mM}$ DTT. Fractions containing cdtB were pooled and concentrated, assayed by UV absorption, and frozen in aliquots at $-80^{\circ} \mathrm{C}$.

We failed to purify cdtB from $S$. flava due to its aggregation into inclusion bodies. $C a$. H. defensa cdtB was expressed at low levels and the final product contained multiple bands. Thus, these proteins were not included in the analysis of DNAse activity.

Mass spectrometry.

Since there were several faint bands on the SDS-PAGE gel in addition to cdtB (Fig. S5), we analyzed trypsin-digested protein by LC-MS/MS and determined they were degradation products of cdtB and not from contaminating nucleases. Trypsin-digested $D r$. ananassae cdtB was submitted to QB3/Chemistry Mass Spectrometry Facility at University of California - Berkeley for LC/MS analysis. $10 \mu \mathrm{g}$ cdtB was denatured and reduced in $6.27 \mathrm{M}$ urea and $9.8 \mathrm{mM}$ DTT at $55^{\circ} \mathrm{C}$ for $20 \mathrm{~m}$. Denatured protein was alkylated by incubation of $19 \mathrm{mM}$ iodoacetamide for $20 \mathrm{~m}$ in the dark. The reaction was quenched by addition of $37.3 \mathrm{mM}$ DTT and followed by overnight trypsin digestion following standard protocols for Trypsin-ultra ${ }^{\mathrm{TM}}$, Mass Spectrometry Grade (New England Biolabs). Trypsin-digested protein sample was analyzed using a Thermo-Dionex UltiMate3000 RSLCnano liquid chromatography system (LC) that was equipped with a C18 column (length: $250 \mathrm{~mm}$, inner diameter: $0.075 \mathrm{~mm}$, particle size: $3 \mu \mathrm{m}$, pore size: $100 \AA$ ) and a $1-\mu \mathrm{L}$ sample loop. The LC was connected in-line with an LTQ-Orbitrap-XL mass spectrometer that was equipped with a nanoelectrospray ionization source and operated in the positive ion mode (Thermo Fisher Scientific, Waltham, MA). Data acquisition and analysis were performed using Xcalibur (version 2.0.7) and Proteome Discoverer (version 1.3, Thermo) software.

Peptides from expressed and purified protein were measured by tandem mass spectrometry. The number of measured peptides can be used to roughly gauge the relative amounts of the different proteins in the sample. The abundance of contaminating native E. coli protein was negligible compared to that of heterologous Dr. ananassae cdtB. We searched UniProt for the contaminant, low-abundance proteins and determined none had known nuclease activity likely to lead to false positives of cdtB nuclease activity.

Nuclease assay.

To determine DNase activity, supercoiled pGEM-7zf+ (Promega) plasmid DNA was incubated with purified cdtB. Reaction volumes were $25 \mathrm{mM}$ HEPES, $5 \mathrm{mM} \mathrm{MgCl}$, $5 \mathrm{mM} \mathrm{CaCl}_{2}$ (vis (65)), $500 \mathrm{ng}$ pGEM-7zf(+) incubated with variable amounts of cdtB from E. coli and $\mathrm{Dr}$. ananassae in $20 \mu \mathrm{L}$ volume. For negative controls, cdtB storage buffer was used. After 2 hours incubation in a $28^{\circ} \mathrm{C}$ water bath, reactions were quenched with the addition of $10 \mathrm{mM}$ EDTA following protocols in (66). Samples were loaded onto a $0.8 \%$ agarose $1 \mathrm{X}$ TBE gel (premixed 
with SYBR Safe) and subjected to electrophoresis for $1.5 \mathrm{~h}$ at $90 \mathrm{~V}$. Images were visualized with AlphaImager TM Gel Imaging System (Alpha Innotech).

\section{Supplementary Text}

Domestication of $c d t B$ following horizontal gene transfer from prokaryotes to eukaryotes

The presence of eukaryotic motifs in putative HTGs after transfer from prokaryotes may indicate adaptive optimization to eukaryotic transcription, translation, and cellular function. Here we summarize how we determined if insect-encoded $c d t B$ is potentially adapted to eukaryotic machinery.

Transcription and translation initiation elements. Thomas and Chiang 2006 (67) provides a comprehensive list of core promoter elements and their consensus sequences identified by transcription initiation factors (TF) TFIID and TFIIB. Other transcription or translation initiation elements we searched for included the Kozak sequence (68-70), the GC box (71), and the CAAT box $(72,73)$. Additionally, a Shine-Dalgarno sequence (a ribosomal binding site in bacterial RNA (74)), can help assess if a putative HTG is actually due to bacterial contamination.

Transcription termination elements. Transcription termination elements are summarized in Proudfoot 2011 (75) and include polyadenylation signals, cleavage site (CA), and upstream and downstream sequence elements (USE and DSE, respectively).

Elements of post-translational processing. Motifs involved in recognition of cargo by accessory proteins of COP and clathrin coated vesicles are described in (76) and were searched using the web-based database LOCATE (77). Additional motifs included mannosylation sites $(78,79)$, sulfation sites $(80)$, nuclear localization signals $(81,82)$, and signal peptides, which were predicted using Phobius and SignalP $(64,83)$.

For the sake of brevity, we here only consider the transcriptional motifs identified bioinformatically in insect $c d t B$ nucleotide sequences. This list is not exhaustive and all elements will not necessarily be found in all eukaryotic genes (84). We did not conduct experiments to confirm the function of the candidate elements. A visual representation of these eukaryotic motifs is shown in Figure S4.

Legend

- Predicted exons are highlighted light blue while predicted introns are yellow. For $D r$. biarmipes and Dr. bipectinata, exons and introns were predicted by (85) as part of the modENCODE project. $C d t B$ regions in Dr. ananassae and $M$. persicae were annotated based on a Gnomon gene prediction set provided by the NCBI (D. ananassae: FBrf0227294; M. persicae: LOC111028693). For $S$. flava, $c d t B$ was annotated by aligning $S$. flava transcriptome (86) to an unpublished $S$. flava genome assembly.

- Coding sequence is light blue and underlined. Thus, 5' or 3' UTRs are light blue, nonunderlined nucleotides.

40 - polyA signals or cleavage sites are highlighted in turquoise.

- Intergenic regions (between the two copies of $c d t B$ in Dr. bipectinata) are lowercase. 
- TATA box motifs are written in orange text, initiator sequence is in purple text, USEs are in grey text and DSEs are in blue text.

Dr. biarmipes

ATAAATAAGGAGAATTTCTTTCTTTTCAGTTTATTATTGAGCATCAAGATGAGAAGAATAAT TTTGAGCCTAGCGTTTCTGACTCGTGTAATGAGTTTAGTTACCGACTACAGACTAACGACAT GGAATTCTCGGGGATATAAATTACATCAAGTTTTCGATTCATTCGCTAGTAATTCATCGTTGA ATATTTTCTTTGTACAAGAAAGTGGAAATTTGGCCGATAAACGTTTAATTTCAATACAACAA AATTTACCAGTAAGTTCAAGGAATATTTTTAAGTATTATACTATATTTTTTTATTATTTTCATT TTTTCTAGTTTTATTTGAATGATGGTAGTAATTCTTATCTATGCGGCGCTTCTGATTTTGTGAA AGTGTACCAATATCAAGATCAAAGGGTTAATTTATATATATATAACTTTTTCCCGCCTCCAAA TGGTATGACACGTTTCGTCATTATACTGATCTTTAATTAATTATATTAATAATACATTTATATT TTCTTCTGCAGTTTTATCAACACTTAGTCTGACAATTGTAAGTCGAGTACCAGCCGATAGTAT AATTTACTTTGCTTCTCTAACGCGGCGACCTGGACGTGCATGCGAGCGAGAGTTTACAAATC GCCCCGTTGCCGGAATAACTATTGGCAACGATGTTTTTCTCAATATTCATGCTGAACCTACGG GCATCAGAAACGAAGTTCCGGATCAATTGGATGCCATTCGAAACCATATGCGCACACATGCT CCGCTTTCATCTTGGTTGCTAGCTGGCGATTTCAACAGAATGCCGTCATCTCTACAATTACAA CCATATAATGAACAATTTGTCGTCCCGCCCCTCAACACCCACGGCAACAAAATTTTGGACTA CCTAATTTTAGGATCTAATGACGTGAGAGTTTTTCAACAAATGGTTAGAAACCCCTATAGCG GAATTGTTGATCTCACTTTAACAGGTTCCGATCACAAGGCTGTACATTTTTCTCTTTGAATCT CACACAATGCCACTATTTTGCCAATGTTTCAAATAATTGTAAAACTGAACACGACTAACACG ATTTTTGAATAAACTCATGGTAAATTCAAA

TATAGATATTTATACATGTTCCATGGCCATGTACTCATCATTCACTAAAAATTGTCCGAATCG CGCAGAACAATGAATAGAGTGCTTTCGTTATTAATTCCAGTTTTACTGAATCAGAATCTCGTT TCTAGTGATGTTACGGATTATAGAATAACGACTTGGAATTCAGAGGGTTATAAACTAGATAA AGTTTTTGACTTATTGGATAAAGACAAGTCCTTAAATTTGGTCTTAGTGCAAGAATGTGGAA ATATTGCAGACAAAAACCCAGGCAGCATTATTAATCCACCTGTACAGGTACATAATTCATAC GTAAACAGTTTCAAGGAATAGATTTATTCAAAATGTACACTTATCTTTTTTTTCTCTAATCTG TCGAAAATAGTTTATAATGATTGACGGTGAAAATGAATACGACTCTGCCAATGATGGTAATT ATGAAATCCGCGAGTATCGAACACGATCCACTCAATTGTTTATATATTATTTTCCGGCACCCA AAAGTGGTAAGTATAAAATTGTTTTCAAGCGCATTTAAAATGCTGTGTGAAAAACTTGGGCA CCATGTTCTCAAGCTTACCTTGTTTGACTAGTTGTTGTAACAGTTTTTTTCTAGAAAAGATAC TAAAAAGTAATTCCTAGATTCGCTTTTTTTTTAATTTTTTAATCTGTTGATGTTTCTTGACTAC AAATCAATGACATAATTCAGAAACTGGAAAATTGAATCCAGGTAAAGATTAATTTCTTGGTG GAATTAATTTGCTATGAAATATTTGTTGTAATAAAATATAAAAGACAATAATGCTATATTAC ATATAAGTTTTAGTTATAAAATGTTTTATCGCACATTTTTATTTCAGTTAATCAGCAATTTGG ATTGGCTATTGTAACCAAACAACTGGCGTCAGAGATATTATACTTTGCATCTCTTCACAATCA CCGAGAAATTATTGATCGCAAGGAACGTTCTTTCATTAATCGTCCTATTGTGGGATTGGTTTT TGGCACTAATGATATTTTTCTTAATTTTCACGCTGAACCCACTAGAAACAACGAAGTTTTACT TCAACTAAATGCAATTAAAACTTATATGAGCCGCTATAAACCCAATGCTTCCTGGATGCTAG GCGCTGATTTCAACCGCGAGCCTGGAGATGTGACTTTGGATCCACATCATGAACGATTGATT CACCCCTCGCAAAATACTCGCCGTAATAGAATAATAGATTACTTTATATATGGTTCTGCAAA TAGAAATGTTTTCGCGCGAATGGCCAAAAAACCTCATACAACAACCATAAATGCTAAGTTGG TCTCTGATCATAAGGCAGTAGATTTTAACCCTGCCCCGAGAGGGTAGTTGGATAAGGTTGTC CAATTCCATCTTTGGCGCCCCCGGGTTAATTATAATTTAAAAAATCAAAGCAACTAGTGACA GTAACACCTTTCGAATTATAACGTATAGCCGAGTCCATGCATTTTATTTTTCGTCGTTTTTGA 
CATTTTGGGATTTAACTCATTTTACATGCATGCATTTTAATCTCTTATACAATTTATAATACA ATGATTTATATACAATCACTATATACAATCATTTATATACAATGAATAATAAATGATAAATG ATTTTTATTTTAAATTAAATTCTTGTGTTT

5

\section{Dr. bipectinata}

AAATATCATCCCAGTACTCATCATTCACTAAACCGTCTCTGATTCGCGCGGAACAATGAACA CGGTGCTTTCATTAATTTTTGCGGTTCTACTGAATCGGAATCTCATTTCTGGTTTAGTTACGG ACTATAAAGTAATGACTTGGAACTCAGATGGTTATAAATTGCAGCAAGTTTTGGATTCATTT TTGAGGAACCCGTCCTTGAGTTTGGCTTTAGTGCAAGAAAGTGGAAATGTTGCTAGGCAAAA CCCAGGCCAAGTCATTCAACAAAATTTAGAGGTACAAATACTCCTAATAAGAAAATTCAATA ATAGTATCTTAATTGCCTTTAAGTAATAGTTTCAAATACTTAATCAAAGTTTAATCCTATTTT TCATTTGAAATAGTTTACTATGGCTGATGGTGAAAATGCATTTCAATGCGCCAATGATGGAT ATTATGAAGTCCGGCAGTATTTTAATCAAGGAACCCGTTTATATATTTATTTTTTCCCCGCAG CCGAAAATGGTAAATACAATAATCTCTCATATTCTATCGATACGTGCTCCAATCGGATTTCCT AGTGAAGTGAATTTATACAATCACCCTTCTGAACAAATTTTTGCACGATTTTATTATACACTG ATTTAATTCAAACTTTAATTTTAGTTCTACAAAAATTGGGATTGACCTTTGTAACCAGACAAC CGGCAACAGAGATACTATACTTCGTATCTCTGCACAATCACCAAGACTGTTTTGATCGCCGC GGAAGTCCTTTTATAAATCGTCCTATTCCGGGATTGGTTTTTGGCAACGACATTTTTCTCAAT TTCCATGCTGAACCCTCTGCAAACAACGAAGTTTTAATTCAACTACGATCCATTAAATCTTTT ATGAGTGTCTACAAACCCAATGCTTCCTGGATGCTAGGCGGCGATTTTAACCGCGAGCCTAG TGGAGTACAATCTGCTTTGGACCAAAACCATGAGCGATTAATTCACCCTTCCCAAAGGACTC GCCGTAATCGCATAATAGATTACTTTATATATGGATCCGCAGATCAAAATGTCTTCGCTCTA ATGAACAGACCTCATACAGCAACTATTAATGCTAATTTGTTCTCAGACCACTATGCTGTAGA TTTTAACCCTGCCCCAAGAAGAGTAGTAGGTTAATAAGTAGGTTAATAATAAATATAACTTA CTCCACACCATACATgaattttaaactcaaacaatttataacaataaatactttgtttattaaaaattaagttctttaaattttgatttttttcaatcact aatctgaagtcgttaagtacttatcggccataagaaccctaggtcttgaaagaaatttcttcaacatttaaacttgataatagtgaaccgctcattgagttcacta tcaagtgggagagtaaacaaaattctgtacaaatctggttttgattgtttgtacgagtgccgataagacaggtctgcagaaaaaaatccctcgaacaatttca ctttctggggctcgcctgaaaaatatgatcacagtactcatcattcattaaacagtTTGTGATCTGCAGAAACAATGAACACAGT GATTTCATTATTATTTGCCGTACTACTTAAACAGAATTTCGTTTATAGTTTAGTTACGGACTA CAATGTTACGACTTGGAATTCACAAGGTTATAGACTACAGCAAGTTTTGGATTTATTTTTAAG CGACCCGTCGTTAAATTTGGCTTTTGTGCAAGAAAGTGGAAATGTTGCTAGCGAAAACCCAG GAAATGTTATTCATCAGAATTTAGAGGTACGGGTGGTTCGAACAAAAAACAAAAATTGGGA ATTCACCTTCTTAAGTGTATTTAATTACACATTTATTGACATAAGAGATGAAATATTATGAAA TGTGACGTGGGTACTGTGTATATTCAAGCTTTTTACTAGATCGTCGTTTTCTGAAAAGTCATT TAATTTCCAACGTAATTTTTCATATTCAATCATTTGAAATAGTTTTACATAGCTGATTCTGAA AATGCATTTGAATGCCGCAATGATGGATATTATGAAGTACGGGAGTATGTAAATCAAGGAA CTCTATTGTATATATATTTTTTTCCCGCGCCTCAAAATGGTGAGTACGATTATCTGTATTATTT TACCAATTTAAACTGCTGTACAATCCCAGTCTTCTATAGAAATTGTTGCCGGAATTGATTACA CTTCACATTTTTATTTCAGTTCGACAAGCACTTGGATTGACTATTGTAAGCAGACATCCGGCG ACAGGGATACTATACTTTGTATCTCAGCATAATCACCGGGCCATATGTGATTCCCGCGACCG TGCATTTATTAATCGACCCGTTGTGGGATTGGTTCTTGGCACTGATGACATTTTCCTCAACAT CCATGCTGAACCCACTCGAACAAGGAACGAAGTACTTACTCAACTAAGAGCCGTTAGATCCC ATATGAGTATCCACAGACCCTCTGCTTCCTGGATGCTAGCAGGGGACTTCAATCGCTTACCT CAAGACGTACAACCCACTTTGATTCAAAACCAAGAACGATTGGTCCAGCCTCCACAAGGTAC TCACGATAACGATGTTCTGGATTACTTTATATATGGGTCCGCAGATCAGACTGTATTCGCGC GAATGGACAGTCCATCAAATCAAGCAACTATTAACCCAACTCTGACCGGCTCGGATCATCAT GCTGTTTATTTTTCCAACTATATTACATCAATTCAATACGATCGAAGCAACCTACAACATATT TTAGATCAAGCATGCACCGTACGAAAAACAAAGTACCACGATTGGACGAACTTTTATGATG AAGTTTACGATGATAAAGATAGGCTACCAAGCGCAGGTTTCATGCAGTTTCAGGACGGATCT TACATGCAACCCGTCGTGGTTGAACGAGATACTGATATCAAAAAGAGCTCCAATTGGTACCC 
GCTTGATTTGTCATTGTTAATTGGGCTTGAGGCCGCATATGCCTACAGTGTAAGGCGTAAAA GGAGCCTTCGTGTGTCTTCTACAACTCATCACGGCTTGATTTTCATGAACCATAAAGGCTCTC CAACCATGACGGTATTTTTAAGAAAAGATAAGTTGCTATGTATGACATGGACCAATAAAGG ATGGAGCAGTCCGACAGAATGTTATCAACACATTTCCCCTGCACAGTTTTCAGCGTCAAGGA ATGAACCGGTATTTGACCCTTAAAATACTAAACTTTACCATTTTAATTACATTCCTTTTTCTG AATACAGACTTTTGATCGTTGTTATAACAAAGCTGAAGAATCAGTTATCAGCGAGAATTTGG AAACATTGGACAAAAATATCCTCAAATCCCGTAACTTGCTTATATTGCAACGTGAGTTTTCA AGAACCATGAGTAAGGATGGACTGTTCAACAATGAATACAATACATTTAAAGACTATTTTAA TGCTAAATGGAATAACACGCTAGTCAGAGATGCTTACGGCATGTCAGGTAATTTACGAATAT GGATCTTAATTGTACATGTTAATTTTACTATGAATCCTTACAAAAAGTCAAACTTTTTTCTAA TTTTAGGACAAGAATTCTGGGTAAAGTCCCTCAGACACTGGAATTTTGGATACTACTTCAAA GATGGATCTTTCTCCGTCGCATTCAGTTCTAAGCATATTCAAAACGGTGACTCCGATAATTGG TTGTTTATAAACGGAAATGAAATTTCCGACTGGGATCCTTGGCTCAGAAACATCTATGGAAT GTTTTTCTTCGACAAGTTCGGACGTCCAGTGATATTCTTTGCAGCTCTTAGTGATTACCCCCA TTGCTGTATCTATAGGAGCCATTGGGTGTACGAATATCGTCCAGATAATAGTTGGGATTGGA TCGAAAACTTTTCAGAATGGGAACCAAGCTTGTTGTCGAAAAACTCAGGCGCTTTGAGATTT ATTGTTGATAAAAACCATATTCACAGTTCATA

\section{S. flava}

AGATTAACAAAGTTTTGCTGGTTTTTTTTCTATGCTTTGCCGTTGCGGCTGCTCAAAACAATT ATAGATTTCTAACTTGGAACACCCAAGGACAACGCTGGCCTCAAGTAACCGCCTATTTGAAT AGATACGATGTGCTATGTATTCAGGAAGCCGGTGCGTTGGGTTTGAGAGGTCTACAGGCTCT TAACCAGAATAATATAGACTATCGAATTGTGGATGAGGACAACAGAGGAGAAATTGTCACA ACATCTGGTTTTAATGGTGGCGTTGAGGCTTATACGTTTTCACATGGAAACGTACCGTATTAT GTCTATTATTATAACCACTTGGTGGAAACTCACGCAGCAAGGGTAGCAAACAATGACCGCA GAACGCGTAACATGGCTATTATAACCCGTGAGCGGGCAAGCAAGGTGTACATTATTCCAGC ACATTCAAGGGATCCATATAGAATTGATGTCAATAGACCAACTATTGGAGTGAAGCTATCAG GATATACGGTCTTCACGGCCCACTCAGATCCAAACAAAAACGAAATCGTCGATACCATTGGA AAAGTGGCTCGTTTTATGGCCAGCGAAAATCAGTGCCAACAAACGAAATGGATTTTAATGG GCGATTTCAACGAAGAGCCAGCAGTTGTAAATCGACGATTGCCTCAAGCTTCAAATGGTTGT GTCATCAGTATAGTGTCTCCCGCAGCTGCCACCAGACAGGCCAGCGGCAAAATTATTGATTA TGGAGTCTATGGCGGTCCACCTAGTACAGCAGGTTCGCTTCAAGCTACCACTAGAACGGGTG AGGGCAACAGTGATCATTGGCCAGTTCAAATTATGCCTGCTCCTATGAATGGCTAAGAAAGC AGTTTGTTTTTGAGAAAAAAAAACATTTTTTAATAAAAAATTGAATTGAAAAAAATGTATA

Interestingly, two long terminal repeats were found flanking $c d t B$ in $S$. flava (see

Supplementary Text), which may indicate retrotransposon insertion events (87). Repeats in $S$. flava were identified in Geneious (57) function "Find Repeats" using minimum repeat length of $100 \mathrm{bp}$ tolerating $10 \%$ mismatches. Two long terminal repeats were found $1,126 \mathrm{bp}$ upstream of the 5' end and 203 bp downstream of the 3' end of $c d t B$ in $S$. flava; they are $379 \mathrm{bp}$ long.

Repeat 1 (5', end):

TTTTTGGCTTGCCGTGCCGTGCTTTAATTATAATTTGGCTTCATTGCAGTTTAGCTGTTGAAA ACAATACGCCAGTGGATGCTGCATTAATCATTCGAAAGCAATTTTTGCGGATTTACATGCGT TGCAGAAAACGATAATTTTCATCCATCATTTTCAAGTGTTTCCGCCAGGATTATAATACCCAG ATAGACATTGCATAGCATCCTGCTGGGCTGGAACAATCCTCTTTGTGTGTTTTTCTTCTACGC TCATTATCCTTCGTTGTCGTCGTCAATTACATTGCAACATCTGAAGCTTTTAGCATTTAGTTG ATGAGCTCGCCTTTTGGCGACCAACTTATCCTTCCATTCCCCGCTCCCGCCTCGAATGATTTA TG 
Repeat 2 (3' end):

TTTTTGGCTTGCCTTGCCGTGCTTTAATTATAATTTGGCTTCATTGCATTTAAGCTGTTGAAAA CAATACGCCAGTGGATGCTGCATTAATCATTCGAAAGAAATTTTTGCGGATTTACATGAGTT GCAGAAAACGATAATTTTCATCCATCATTTTCAATTGTTTCCGCCAGGATTATAATACCCAGA TAGACATTGCACAGCATCCTGCTGGCCTGGAACAATCCTCTTTGTGTGTGTTTCTTCTACGCT CATTATCCTTCGTTGTCGTCGTCAATTACATTGCAACATCTGAAGCTTTTAGCATTTAGTTGA TGAGCTCGCCTTTTGGCGACCAACTTATCCTTCCATTCCCCGCTCCCGCCTCGAATGATTTAT G

M. persicae

TATATAAGGCCGACTTTTAGCGTACTGTAGGTACTATAGGTTAGGTTAGGTACATTATAATA TTGCTTATTATTTATCAACATATATATATATAACGTGAATTAAAAAAAATTTAACATTTAAAA CTATAAGTTAGAAGCTGAAATAATATCTACAGAATGGCGACAATAGTCTTGCTATTATTAAT TTCTCAGCTTATAAATTATAATTTAATTTCGTGTTTAGTTACTGATCACCAAATAGTAACTTG GAATTCAAATGGCTACAAACTCCCAAAAGTTTTTGCTTTCTTGGATAAGAATCCACGTATAC ATTCAGTTTTTGTGCAAGAAAGTGGAAATGTTGAATCTGAATCAAATAATGCAGGAACTCCA GTACCGAAAACTAATTTACCAAAAGTATAAGGATTTTTAATTTTGATACAATTATTGTATAAT ATATTTAAATATTTGATATTTTTTAATTTTTTAAAATATTTTAATTTATAGTTTAATGTCTCAA ATATAATTTTTTTATATTTAATTAAATATAATAATCATATTTTTATAATTATTTTATATTAAAA AAAATGATTTTTTTAAATAGTTTGTTATTGCTGACGTAGAAGGTGATATCGAATGTACGAATT ATGCTGACTTTATTAAAGTCAAAACTGTAACGACATTTCAAAACGGGCCGTTTTATATATATT ATTCACCTGCATCCCCCAATGGTAAGTAACATCAAATAATTTCAATAATACCTACAATTTTCA TATTATTTTGTACTTCTATTATCTAGTTACTCCCAAAATTAGCATAACTATTGTAAGCAGACA TTTAGCTAGAGAGATAATACTTTTTCCAAGTCAACACAATCATAAGAGTGTATGTCACGATC GTGCTTATACTAACCGCCCTATTATTGGATTGGTTTTACAAAATAATCAAAATAATCAAAAA AATTATGATATTATTTTAAATATTCACGCGGAACCAACTAGAAAACGTAACGAAGTGATAAC ACAATTGAAAATTATCAGAACTTATATGAATACCATTAGAAAACCTACTTCATGGTTGTTAG CCGGTGATTTTAATCAATTACCTGAAGACATTATAAGTGAATTAAAATCTCAAGAACAAATA GTCACACCAAATGATAATACTCATGCTACTCATATTCTCGATTTTTTAATATATGGTTCCCCT GATGTTCAAATTTTTTCGAAGATGAAAAATTCTCAATATAAAGGAGAAATAGTGGAAAAGG ATTTGATTTCAGATCATAAAGCCGTGCATTTTTTTAAGTAGTTAGGTAATTTTTTATTAATGTT TATTATTTTGGTGTTAGCGCATTGTATTCATCAAATATTTGTGAATTTTATTATTAAATTTATT TTTATTTAACATAATAATTTATTAAGTAGGTACCTATATTTTACTATGGTCTGAATGACTGAA TTTTGATGATTGATGATTGTCTATAATATAATATGATAGCCATTACACCATATTCAAAATAAT AAGTACCTATTGTATATTTAAATAATTAAATTATATTTCATAGGTAACATGTATTTTTTAAGT TATTTATTTAAGAATTTTAAATGTATTTTCACTCACAAAAAAAACAAATATGAATTGTACAAT TGAGAAAACTCGGGGTCATAGAATAATCATTTTTGATAAAATAAATCGTTTATAATATTTTA CTGTATACCGACTATTATAATTTGATAATTAATGTATTGTC 
Apoptosis inducing protein 56 is fused at the $\mathrm{C}$ terminus with cytolethal distending toxin $\mathrm{B}$ in Dr. bipectinata and other ananassae subgroup species

Apoptosis inducing protein 56 is fused at the C terminus with cytolethal distending toxin B in Dr. bipectinata and other ananassae subgroup species. The full cdtB alignment (Figure S7) shows a large C-terminal region of the second Dr. bipectinata copy (with five exons) does not align to that of any other cdtB sequences except two other species in the ananassae species subgroup, $D r$. pseudoananassae nigrens and Dr. ercepeae. To determine if this region was a bacterial contamination artifact, we amplified and sequenced this region from Dr. bipectinata via RT-PCR and Sanger sequencing, which confirmed that this region had introns (leading us to disfavor bacterial contamination) and overlaps the $c d t B$ domain (disfavoring errant colocalization of the two genes by assembly error), which corroborated data from (85). We extracted this conspicuous region (residues 294-651 from XP_017099943.1) and submitted it as a BLASTP query (Table S8a), which showed the region has high homology to another $\mathrm{Ca}$. H. defensa protein, hypothetical protein $\mathrm{D}(88)$. Interestingly in the $\mathrm{Ca}$. H. defensa $5 \mathrm{AT}$ strain genome (NC_012751.1) the two genes $c d t B$ (KF551594.1) and ORF D (DQ09613.1:2421-3185) are ca. $255 \mathrm{bp}$ apart. Since we identified relatively few hits in the first BLASTP search and high divergence may have limited the number of identified homologs, we subsequently ran a BLASTP search using the $C a$. H. defensa hypothetical protein D (WP_015874047.1) as a query (Table S8b). Our results show that the second half of D. bipectinata cdtB has homology to the protein apoptosis inducing protein 56 (aip56), a key virulence factor of Photobacterium damselae piscida, one of the most important bacterial diseases in mariculture (89). Aip56 is secreted by the type II secretion system of $P$. damselae piscida (90). In infected fish, aip56 triggers apoptosis of macrophages and neutrophils, which leads to infection-associated necrotic lesion that can devastate a population (91).

Aip56 may have been transferred horizontally in other eukaryotic species. Interestingly, copies of aip56 were also found in the genomes of two other insect species: Operophtera brumata, the winter moth, and Danaus plexippus plexippus, the monarch butterfly. However, the two aip56 homologs (OWR44524.1, OWR45007.1) identified in Da. plexippus were located on short scaffolds containing only the gene of interest, suggesting these may be bacterial contaminants. While aip56 homologs found in O. brumata were also found on relatively short scaffolds (1.6kb - KOB51764.1; $52 \mathrm{~kb}$ - KOB69574.1; 48kb - KOB68847.1, KOB68849.1) the two former identified scaffolds encoded other bona fide insect genes. Additionally, the latter scaffold had two aip56 orthologs arranged in tandem, one of which contained an intron. Here, we only considered aip56 homologs to be insect-encoded if they were found on scaffolds containing other bona fide insect genes. Thus, we include Dr. bipectinata aip56 and at least three O. brumata aip56 copies. A previous study determined via phylogenetic network analysis that eukaryotic aip56 sequences cluster together, and are closely related to APSE-2 hypothetical protein D (92).

Aip56 is an AB-toxin, but only residues in the $B$ domain appear to be conserved between eukaryotic and prokaryotic species. Aip56 is an AB-toxin (89). While relatively little is known about aip56, motifs have been discovered that facilitate their cytotoxicity, which manifests as induction of apoptosis in eukaryotic cells $(93,94)$. Aip56 is composed of two domains linked by 45 a disulphide bridge: the A domain is responsible for catalytic activity and the $\mathrm{B}$ domain facilitates cellular entry of the toxin. One of the key components of the A domain is a HEXXH 
motif which is typical of zinc metalloproteases and is highly conserved within bacterial species (95). The A domain cleaves the transcription factor NF-KB 65, thus interfering with the regulation of inflammatory, anti-apoptotic genes (95), affecting bacterial pathogenicity. In an alignment of all aip56 sequences we identified in Table S8, an HEXXH motif was found in all bacterial species except in $\mathrm{Ca}$. H. defensa, and was absent in all insect-encoded copies (Figure S8). In the B domain, unlike the A domain, we could identify several motifs that appeared to be conserved between eukaryotes and prokaryotes (e.g. FD ${ }^{695-696}$, GRP ${ }^{698-700}$ ). While the mechanisms behind B domain cellular entry are less defined, it is known that a deletion of this delivery module domain inhibits binding to target cells and reduces cytotoxicity, making it plausible that these residues are important in cellular uptake (95). Given that this domain is vital in cellular entry in diverse hosts $(89,91)$, their conservation across domains of life may signal a vital role in facilitating clathrin-dependent endocytosis, the mechanism of aip56 and cdtB uptake $(91,96)$. Both cdtB and aip56 also undergo endosomal maturation in host cells prior to inducing cytotoxic effects $(91,97)$, suggesting compatibilities in their methods of cytoplasmic delivery that may have facilitated the $c d t B+$ aip 56 fusion in the ancestor to $D r$. ananassae subgroup species.

Hypotheses on the history, functions and mechanisms of cdtB + aip56 fusion protein. The fusion of $c d t B$ and aip56 in Dr. bipectinata, along with the proximity of those two genes in the $C a$. H. defensa genome, strongly suggests that these two genes may have been horizontally transferred between ancestors of $\mathrm{Ca}$. H. defensa APSE-2 and eukaryotes, either directly from a phage or via a bacterial intermediate (98-100). These two genes, which are encoded in an operon-like fashion in $\mathrm{Ca}$. H. defensa, are close enough (within $300 \mathrm{bp}$ ) that small mutations could have led to readthrough mutations or frameshift mutations and to the two individual proteins being expressed and translated as one larger protein (101). CDTs and aip56 are both AB toxins, and in $D r$. bipectinata + Dr. pseudoananassae only the A subunit of the CDT, encoded by $c d t B$, and the B subunit encoded by aip56 are found in these species. Thus, it is plausible that this ctdB+aip56 fusion was adaptive in some insect backgrounds because these two protein domains can work in concert to affect cellular internalization (aip56 B domain) followed by DNase and apoptogenic activity (cdtB). We speculate that the shared cellular internalization pathways of both cdtB and aip56 (clathrin-mediated endocytosis and endosomal maturation) are in fact synergistic. We hypothesize that the $c d t B+$ aip 56 fusion represents a unique adaptation to the same problem $c d t B$ may have evolved in response to. However, it is also clearly not the only viable way of affecting cdtB function, since we could not find aip56 in Dr. ananassae, Myzus spp., or Dr. primaeva + 35 Scaptomyza spp. genomes. 
Analysis of $c d t B$ synteny within drosophilid and aphid lineages

In order to assess the evolutionary history of horizontal transfer in $c d t B$ within and among insect species, we analyzed synteny of $c d t B$ in aphid and drosophilid species $(26,102-105)$. We downloaded Scaptomyza, Drosophila and Macrosiphini aphid scaffolds and compared gene identity up- and down-stream of $c d t b$ in SynMap using CoGe (106). SynMap revealed clear $c d t B$ synteny between species in each of these three clades: Dr. bipectinata + Dr. ananassae, Dr. primaeva $+S$. flava, Di. noxia $+M$. persicae $+M$. cerasi, and none between Dr. biarmipes and any other species.

Additionally, since variability in scaffold size between species could limit syntenic inference, we used a complementary microsyntenic approach and manually identified genes flanking $c d t B$ (see Table S9) in representative drosophilids, which corroborated the results from CoGe.

Comparison of $c d t B$-containing scaffolds to those in Dr. melanogaster indicate that $c d t B$ is located on Muller element E (chromosome 4) in S. flava and Dr. primaeva. In contrast, $c d t B$ is located on Muller element B (chromosome 3R) in Dr. ananassae and Dr. bipectinata as well as in the more distantly related $\mathrm{Dr}$. biarmipes (107).

Results for the above SynPlot analyses can be regenerated at the following links:

- Dr. ananassae to Dr. bipectinata: https://genomevolution.org/r/qc71

- Dr. ananassae to S. flava: https://genomevolution.org/r/s735

- Dr. ananassae to Dr. biarmipes: https://genomevolution.org/r/s3ze

- Dr. bipectinata to Dr. biarmipes: https://genomevolution.org/r/s3zk

- Dr. biarmipes to S. flava: https://genomevolution.org/r/s737

- S. flava to Dr. primaeva: https://genomevolution.org/r/135zl

- M. persicae to M. cerasi: https://genomevolution.org/r/1214j

- Di. noxia to M. persicae: https://genomevolution.org/r/139ic 
Fig. S1.
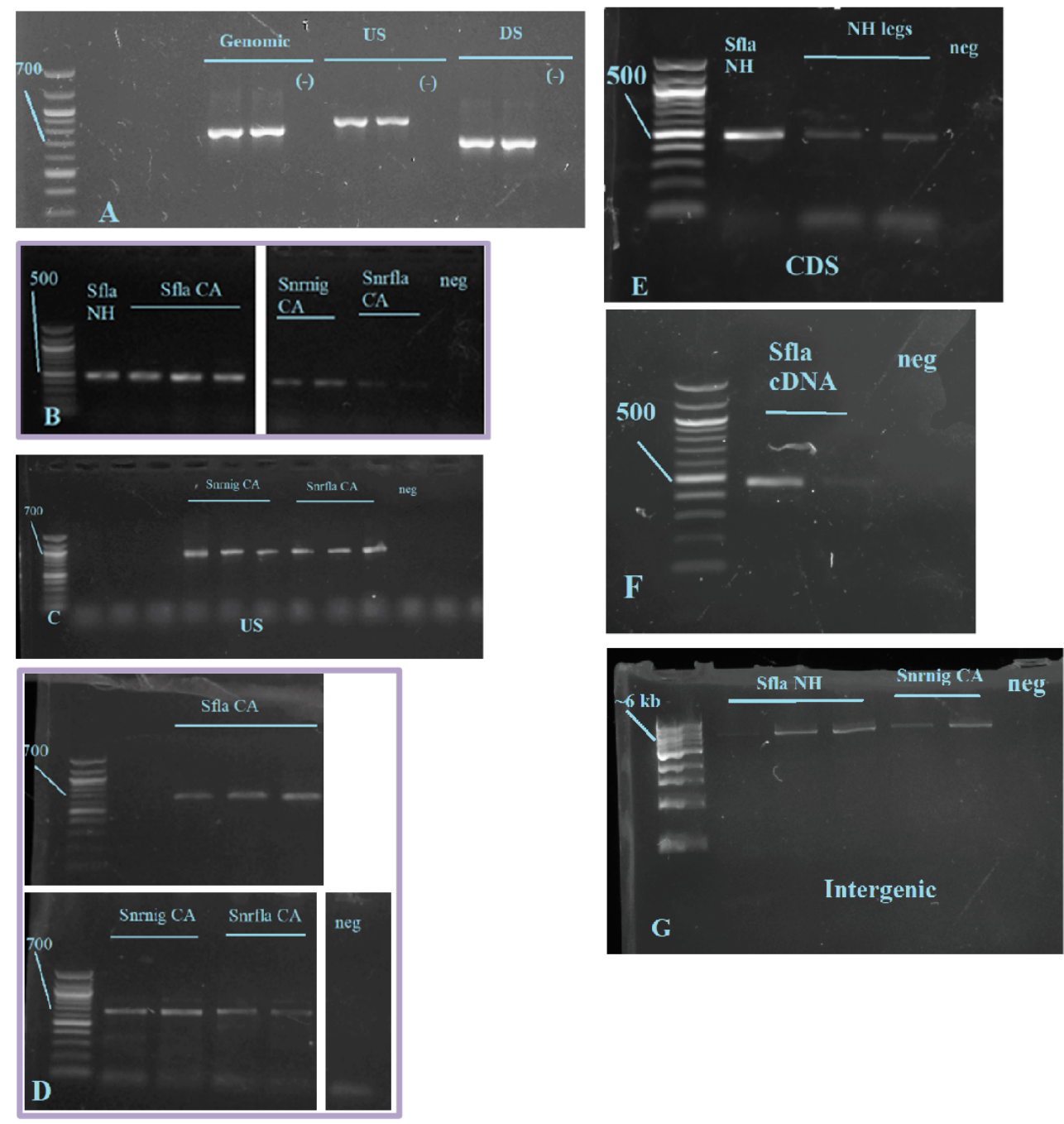

Fig. S1. Gel images of amplicons using primers from Table S3. Throughout, Sfla NH refers to $S$. flava colonies originally captured from New Hampshire, USA and maintained at UC-Berkeley. Sfla CA refers to $S$. flava collected from Berkeley, CA that are $100 \%$ identical at COI to $S$. flava from NH. Snrnig CA refers to $S$. nr. nigrita captured from Berkeley, CA. Snrfla CA refers to $S$. nr. flava collected from Berkeley, CA. Spal refers to S. pallida. 'Neg' or (-) refers to negative controls with nuclease-free water substituted for template DNA. Unless otherwise specified, $c d t B$ was amplified from single whole bodies of the drosophilid species. In all figures O'Gene Ruler $100 \mathrm{bp}$ Ladder (ThermoFisher) is used in the first well (except for item G, in which O'Gene Ruler $1 \mathrm{~kb}$ Ladder (ThermoFisher) is used). Numbers adjacent to the ladder are approximate size in bp. $1 \%$ agarose $1 \mathrm{X}$ TBE gels were stained with $0.01 \%$ SYBR $^{\mathrm{TM}}$ Safe. Amplification from heads and/or legs in E, $\mathrm{H}$ and I indicates that $c d t B$ is unlikely to be from contamination of gut 15 bacteria. In images B, D and L, different images from the same gel and primer set are stitched together for clarity, these divisions are indicated by white lines. Besides these concatenations, these images are not subject to any nonlinear adjustments, and are indicated by a purple border. 
bioRxiv preprint doi: https://doi.org/10.1101/544197; this version posted February 9, 2019. The copyright holder for this preprint (which was not certified by peer review) is the author/funder, who has granted bioRxiv a license to display the preprint in perpetuity. It is made available under aCC-BY-NC-ND 4.0 International license.

Fig S1 contd.
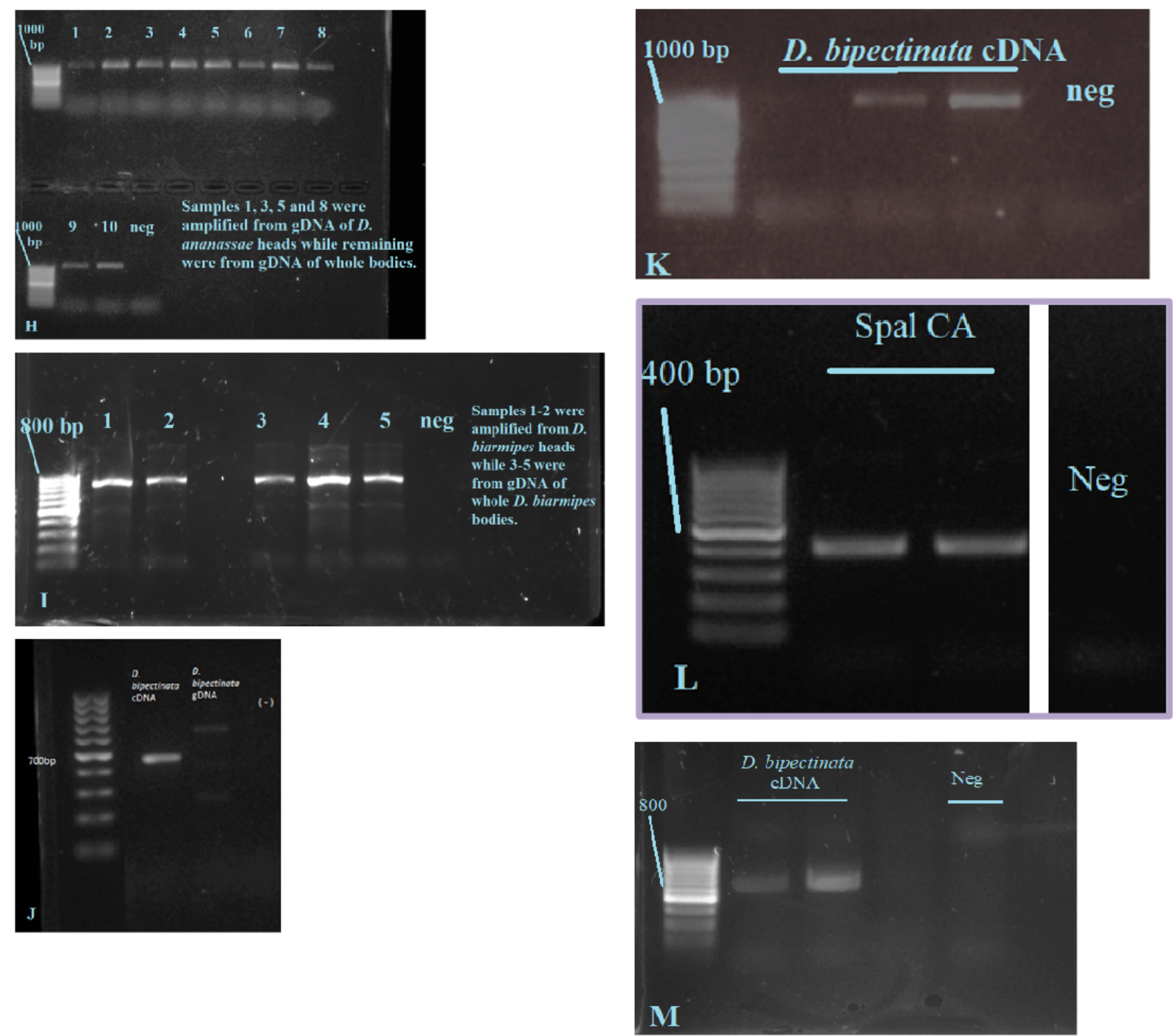
bioRxiv preprint doi: https://doi.org/10.1101/544197; this version posted February 9, 2019. The copyright holder for this preprint (which was not certified by peer review) is the author/funder, who has granted bioRxiv a license to display the preprint in perpetuity. It is made available under aCC-BY-NC-ND 4.0 International license.

Fig. S2.

Tree scale: 0.1

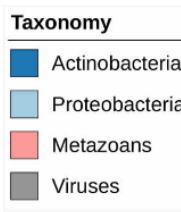

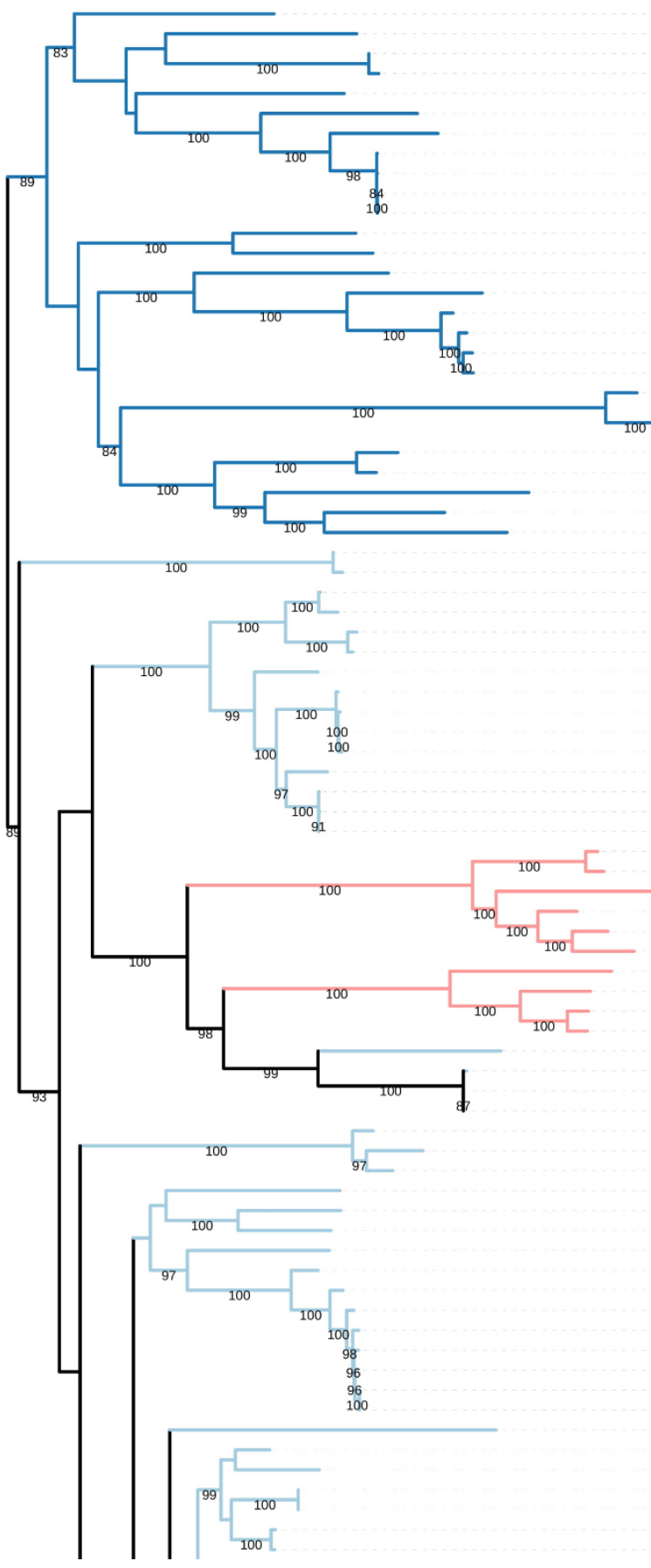

WP 100581545.1-2020327-Streptomyces sp CB02120-Actinobacteria

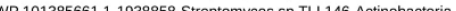

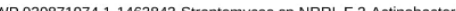

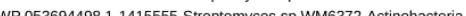
WP 0338001 141444708 Kits

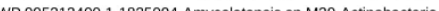

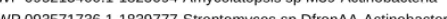
WP 0357136.1 -1839777-Streplomyces sp DironAA-Actinobacteria WP 093040 . WP 030706149.1-1911-Streptomyces sp MnatMP M-Actinobacter WP 003964-1-1911-Streptomyces griseus subs-Actinobacteria WP 003064247.1-1609288-Streptomyces sp ACT 1-Actinobacteria WP 052770355 1-356851-Micromonospora chokoriens-Actinobacteria WP 083646557-1-17403-Streptomyces sp CNQ 509-Actinobacteria WP 053724408.1-1415357-Streptomyces sp WM6378-Actinobacteria WP 058041810.1-1488406-Streptomyces sp MBT76-Actinobacteria WP 099198809.1-53446-Streptomyces cinnamoneus-Actinobacteria WP 086566798.1-173770-Streptomyces alboverticil-Actinobacteria WP 052706017.1-1609106-Streptomyces sp NRRL B 1-Actinobacteria WP 093599780.1-1839780-Streptomyces sp MnatMP M-Actinobacteria

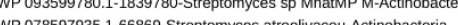
WP 107428536 1-1703921-Streptomyces Sp CB02050-Accinoct WP 09143717211.93228 WP 067311347 1-201504 Micro WP 001937917 -2001-Streptospon

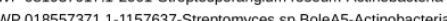
WP 06375241.1 -1157637-Streptomyces sp BoleA5-Actinobacteria WP 081334192.1-669-Vibrio harveyi-Proteobacteria WP 080100218.1-670-Vibrio parahaemolyticus S-Proteobacten WP 049600395.1-685706-Yersinia nurmii-Proteobacteria WP 064517904.1-935293-Yersinia entomophaga-Proteobacteria WP 080985521.1-29486-Yersinia ruckeri-Proteobacteria WP 080774139.1-29486-Yersinia ruckeri-Proteobacteria WP 005158128.1-630-Yersinia enterocolitica s-Proteobacteria WP 005278567.1-634-Yersinia bercovieri-Proteobacteria WP 057649187.1-630-Yersinia enterocolitica-Proteobacteria WP 049603041.1-634-Yersinia bercovieri-Proteobacteria WP 054872106 1-634-Yersinia bercovieri-Proteobacteria WP 050295358 1-29484-Yersinia frederiksenii-Proteobacteria WP $0190033691-630$-Yesin WP 019083309.1-630-Yersinia enterocoitica-Proteobacteria WP 050298305.1-630-Yersinia enterocolitica-Proteobacteria XP $020030779.1-330$-ersina enteclica XP 022163116.1-13164-Myzus persicae-Meta new-93721-Myzus cerasi-Metazoa

XP 016950904.1-125945-Drosophila biarmipes-Metazoa XP 017099943.1-42026-Drosophila bipectinata-Metazoa XP 017099970.1-42026-Drosophila bipectinata-Metazoa XP 014760894.1-7217-Drosophila ananassae-Metazoa new-46814-Drosophila primaeva-Metazo new-7300-Scaptomyza pallida-Metazoa new-928822-Scaptomyza flava-Metazoa new-928823-Scaptomyza nr nigrita-Metazoa WP 016857353.1-138072-Candidatus Hamiltonella d-Proteobacteria WP 100096556.1-138072-Candidatus Hamiltonella d-Proteobacteria YP 002308521.1-340054-Bacteriophage APSE 2-Viruses WP 015874046.1-138072-Candidatus Hamiltonella d-Proteobacteria WP 084185923.1-170674-Vibrio pacinï DSM 19139-Proteobacteria WP 0655762091-723171-Vibrio genomosp F10-Proteobacteria

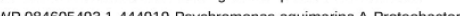
WP 0300543.1 - 44 191 -Psychromonas aquimarina A-Proteobacteria WP 0360054.1-400061-Paludibacterium yongneupe-Proteobacteria WP $07927917.1-287$ - sexdomonas aenginosa-Proteobactenta WP $098493060.1-1801062$-Collmonas sp PA H2-Proteobacteria WP 049780971.1-158327-Hahella chejuensis KCTC 2-Proteobacteria WP 081723669.1-312026-Paraburkholderia mimosaru-Proteobacteria WP 094778928.1-1247936-Paraburkholderia ribeiron-Proteobacteria WP 087737881.1-1701573-Paraburkholderia piptaden-Proteobacteria WP 015004717.1-252970-Paraburkholderia phenolir-Proteobacteria WP 081767791.1-1080179-Burkholderia sp UYPR1 41-Proteobacteria WP 090873756.1-667676-Paraburkholderia diazotro-Proteobacteria WP 012406728.1-75105-Paraburkholderia caribens-Proteobacteria WP 012406728.1-148447-Paraburkholderia phymatum-Proteobacteria WP 023930169.1-29419-Helicobacter canis NCTC 1-Proteobacteria WP 104699394.1-152490-Helicobacter marmotae-Proteobacteria WP 023383973.1-196-Campylobacter fetus subsp-Proteobacteria WP 066455293.1-2020249-Helicobacter sp CLO3 hu-Proteobacteria WP 066455293.1-211-Helicobacter sp CLO 3-Proteobacteria WP 110522214 1-213-Helicobacter cinaedi-Proteobacteria WP 104742561.1-213-Helicobacter cinaedi-Proteobacteria

Fig. S2. CdtB protein maximum likelihood phylogeny incorporating sequences from NCBI refseq protein database and those found in this study. Numbers on branches are support values from 1000 bootstrap replicates. The names at the tips indicate the NCBI Protein ID (if not found in this study, in which case it is described as 'new'), species name and domain. For a further description of this phylogeny, please see Materials and Methods. 
bioRxiv preprint doi: https://doi.org/10.1101/544197; this version posted February 9, 2019. The copyright holder for this preprint (which was not certified by peer review) is the author/funder, who has granted bioRxiv a license to display the preprint in perpetuity. It is made available under aCC-BY-NC-ND 4.0 International license.

Fig $S 2$ contd.

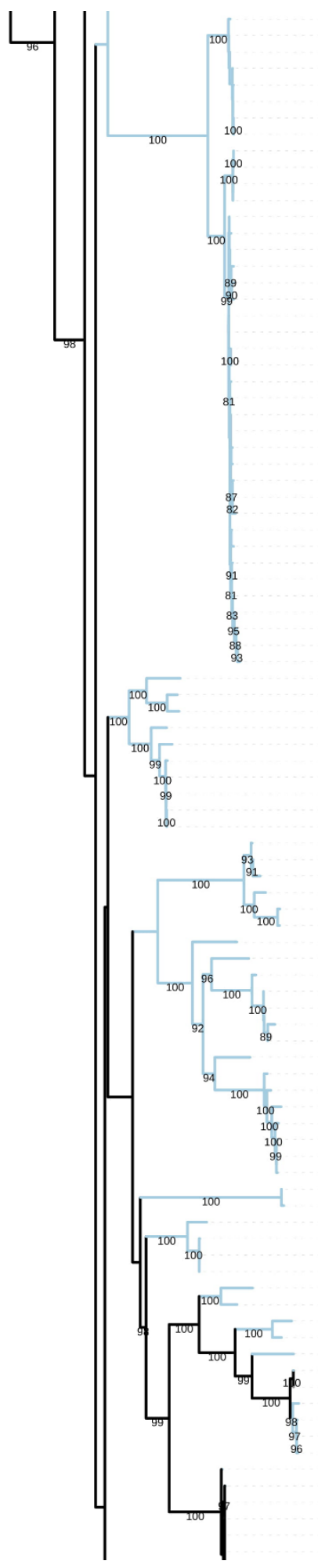

WP 086247676.1-1895640-Campylobacter sp S0112-Proteobacteria WP 086334140.1-1660074-Campylobacter sp RM8964-Proteobacteria WP 086249422.1-1895634-Campylobacter sp RM8965-Proteobacteria WP 086316004.1-1660076-Campylobacter sp RM12175-Proteobacteria WP 086257405.1-1895638-Campylobacter sp RM9262-Proteobacteria WP 086303172.1-1895639-Campylobacter sp RM9263-Proteobacteria WP 096030656.1-1895637-Campylobacter sp RM9261-Proteobacteria WP 086237427.1-1895631-Campylobacter sp P0078-Proteobacteria WP 086237427.1-1660073-Campylobacter sp RM6137-Proteobacteri WP 086242672.1-1895632-Campylobacter sp P0124-Proteobacteria WP 086242672.1-1895630-Campylobacter sp P0024-Proteobacteria WP 086298138.1-1895615-Campylobacter sp P0187-Proteobacteria WP 086241382.1-1895626-Campylobacter sp P157-Proteobacteria WP 086301940.1-1660064-Campylobacter sp NCTC 13-Proteobacteria WP 086240568.1-1895617-Campylobacter sp P0222-Proteobacteria WP 086268795.1-1895602-Campylobacter sp P0103-Proteobacteria WP 086304123.1-1895609-Campylobacter sp P0134-Proteobacteria WP 086224994.1-1895601-Campylobacter sp P0098-Proteobacteria WP 086224994.1-1895605-Campylobacter sp P0108-Proteobacteria WP 086235169.1-1895614-Campylobacter sp P0140-Proteobacteria WP 086235169.1-1895629-Campylobacter sp P162-Proteobacteria WP 086245414.1-1895622-Campylobacter sp P093-Proteobacteria WP $086306969.1-1895007$-Campylobacter sp P0111-Proteobacteria WP 086239063.1-1895596-Campylobacter sp P0023-Proteobacteria WP $03632101.1-105013$ Calo WP $0862907261-1095604$ Capplobacter sp P0107 Probatenta WP 080200726.1 185504.Campylobacter sp PO107. Proteobacteri WP 086231981 1-1895610-Campylobacter sp P0135-Proteobacteria WP 086235603.1-1895628-Campylobacter sp P160-Proteobacteria WP 096018545.1-75658-Campylobacter lanienae-Proteobacteria WP 086229970.1-1895599-Campylobacter sp P0088-Proteobacteria WP 086228859.1-1895606-Campylobacter sp P0109-Proteobacteria WP 086270460.1-1895603-Campylobacter sp P0106-Proteobacteria WP 086280000.1-1895595-Campylobacter sp P0021-Proteobacteria WP 086287486.1-1895597-Campylobacter sp P0085-Proteobacteria WP 086289961.1-1895625-Campylobacter sp P155-Proteobacteria WP 086278421.1-1895600-Campylobacter sp P0094-Proteobacteria WP 086243249.1-1895618-Campylobacter sp P0227-Proteobacteria WP 065843539.1-196-Campylobacter fetus subsp-Proteobacteria WP 095227920.1-1905758-Helicobacter sp 13S00401-Proteobacteria WP 095278414.1-1476195-Helicobacter sp 11S02629-Proteobacteria WP 075495167.1-1780362-Campylobacter geochelonis-Proteobacteria WP 038452504.1-1244531-Campylobacter iguaniorum-Proteobacteria WP 059429813.1-198-Campylobacter hyointestin-Proteobacteria WP 104066693.1-198-Campylobacter hyointestin-Proteobacteria WP 059435158.1-196-Campylobacter fetus subsp-Proteobacteria WP 059432846.1-198-Campylobacter hyointestin-Proteobacteria WP 059432846.1-196-Campylobacter fetus subsp-Proteobacteria WP 057515463.1-28901-Salmonella enterica subsp-Proteobacteria WP 100212520.1-28901-Salmonella enterica subsp-Proteobacteria WP 070789212.1-28901-Salmonella enterica subsp-Proteobacteria WP 053530118.1-28901-Salmonella enterica subsp-Proteobacteria WP 079777855.1-54736-Salmonella bongori serova-Proteobacteria WP 079774830.1-54736-Salmonella bongori serova-Proteobacte WP 078239105.1-123822- Haemophilus felis-Proteobacteria WP 1117497779.1-2094024-Glaesserella sp HHC 2018-Proteobacteria WP 078208148.1-738-Glaesserella parasuis-Proteobacteria WP 078208485.1-738-Glaesserella parasuis-Proteobacteria WP 021110630.1-738-Glaesserella parasuis SWI-Proteobacteria WP 078218785.1-733-Haemophilus haemoglobinop-Proteobacteri WP 049214703.1-747-Pasteurella multocida-Proteobacteria WP 101775199.1-1071947-Pasteurella oralis-Proteobacteria WP 077463831.1-1906744-Rodentibacter heyli-Proteobacteria WP 010944837.1-730- Haemophilus ducreyi-Proteobacteria WP 025298157.1-714-Aggregatibacter actinomyc-Proteobacteria WP 005589325.1-714-Aggregatibacter actinomyc-Proteobacteria WP 094978761.1-714-Aggregatibacter actinomyc-Proteobacteria WP 033534345.1-123899-Bordetella trematum-Proteobacteria WP 025515040.1-123899-Bordetella trematum CCUG-Proteobacteria WP 065236386.1-505345-Gallibacterium genomosp-Proteobacteria WP 021724663.1-728-Avibacterium paragallinar-Proteobacteria WP 046097624.1-728-Avibacterium paragallinar-Proteobacteria WP 052718511.1-728-Avibacterium paragallinar-Proteobacteria WP 071991045.1-93378-Edwardsiella hoshinae-Proteobacteria WP 080102909.1-28901-Salmonella enterica subsp-Proteobacteria WP 032479052.1-666-Vibrio cholerae-Proteobacteria WP 045718172.1-28901-Salmonella enterica subsp-Proteobacteria WP 059330987.1-562-Escherichia coli-Proteobacteria WP 000759934.1-2093881-Escherichia sp MOD1 EC60-Proteobacte YP 008766957.1-1357825-Enterobacteria phage fiAA-Viruses WP 080675667.1-126385-Providencia alcalifaciens-Proteobacter WP 059219457.1-208962-Escherichia albertii-Proteobacteria WP 095574037.1-208962-Escherichia albertili-Proteobacteria WP 000759936.1 -208962-Escherichia albertil TWI5-Proteobacteria WP 105275841.1-2093900-Escherichia SP MOD1 EC70-Protectich WP 000734592.1-208962-Escherichia albertii TW15-Proteobacteri WP 000734593.1-1776082-Shigella dysenteriae S620-Proteobacteria WP 000734593.1-562-Escherichia coli-Proteobacteria WP 000734593.1-622-Shigella dysenteriae-Proteobacteria 
bioRxiv preprint doi: https://doi.org/10.1101/544197; this version posted February 9, 2019. The copyright holder for this preprint (which was not certified by peer review) is the author/funder, who has granted bioRxiv a license to display the preprint in perpetuity. It is made available under aCC-BY-NC-ND 4.0 International license.

\section{Fig $S 2$ contd.}

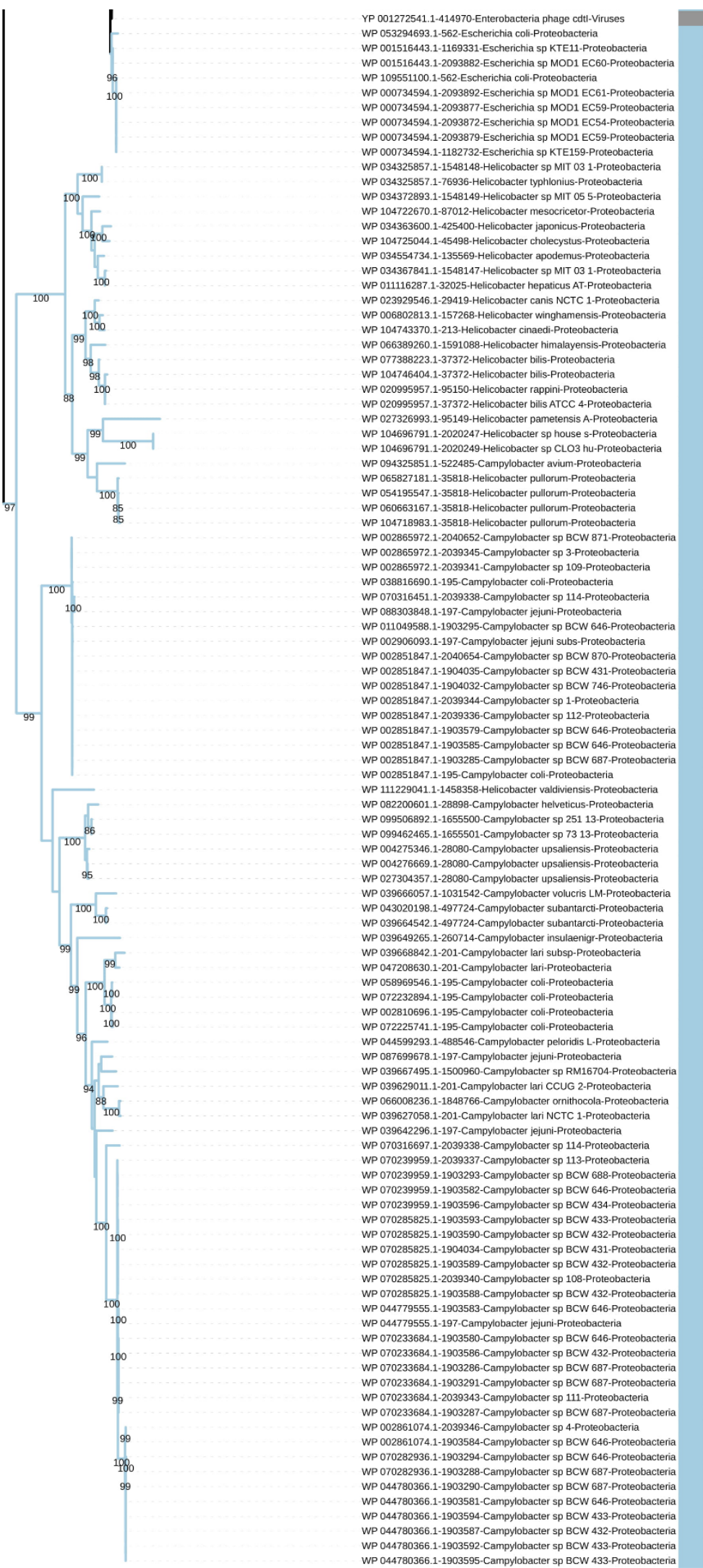




\section{Fig. S3.}

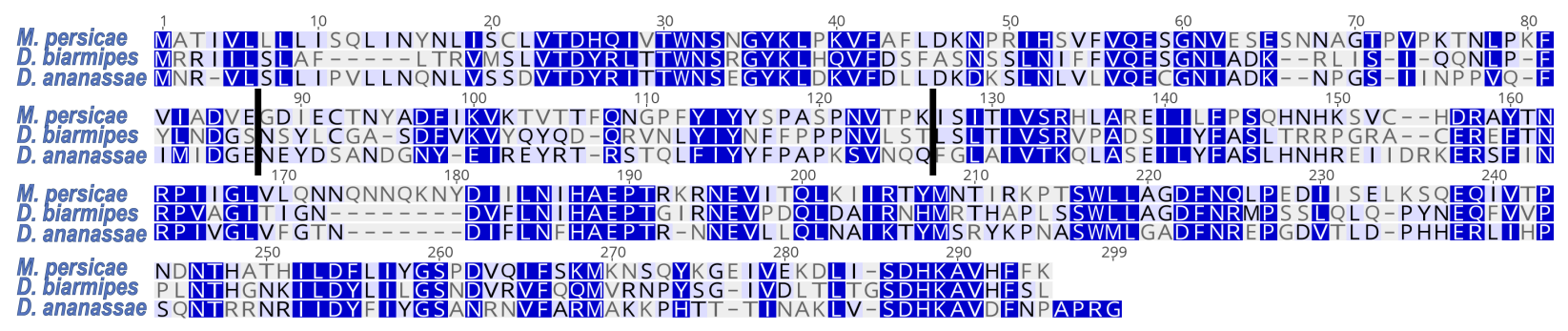

Fig. S3. MUSCLE cdtB amino acid alignment for representative intron-containing copies of cdtB. Splice junctions (indicated by black lines) are conserved in a MUSCLE alignment cdtB copies from Dr. ananassae, Dr. biarmipes and M. persicae. Blue scale corresponds to similarity under the Blosum62 scoring matrix with a threshold of 1 (where darker shading corresponds to higher similarity). Numbers indicate alignment residues. 


\section{Fig. S4.}
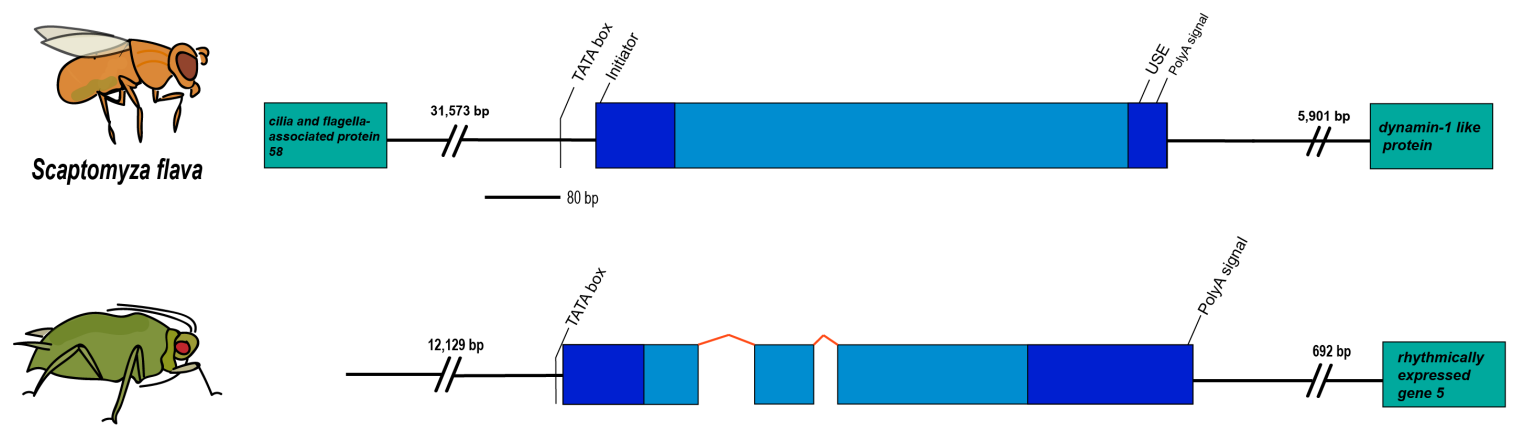

Myzus persicae
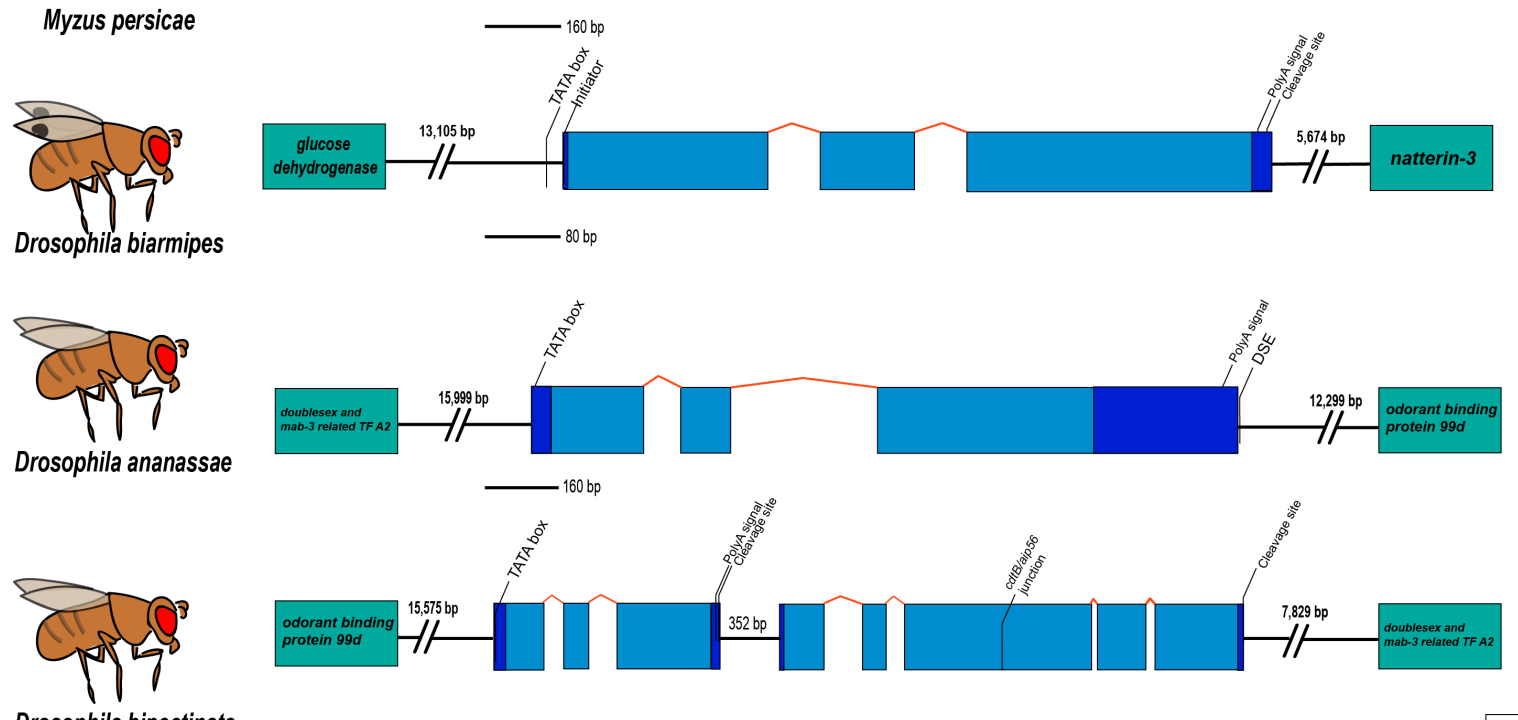

Drosophila bipectinata

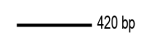

Fig. S4. Gene region and eukaryotic motifs of $c d t B$ in representative insect species. UTRs are 5'3' left to right. Dark blue boxes are UTRs, orange bent lines are introns, and light blue boxes are exons. Boxes to the left and right are nearest flanking genes and brackets indicate distance to nearest gene. Slanted lines with floating text indicate motifs described in the Supplementary Text. Gene representations are drawn approximately to scale with calibration legends. 
bioRxiv preprint doi: https://doi.org/10.1101/544197; this version posted February 9, 2019. The copyright holder for this preprint (which was not certified by peer review) is the author/funder, who has granted bioRxiv a license to display the preprint in perpetuity. It is made available under aCC-BY-NC-ND 4.0 International license.

\section{Fig. S5}

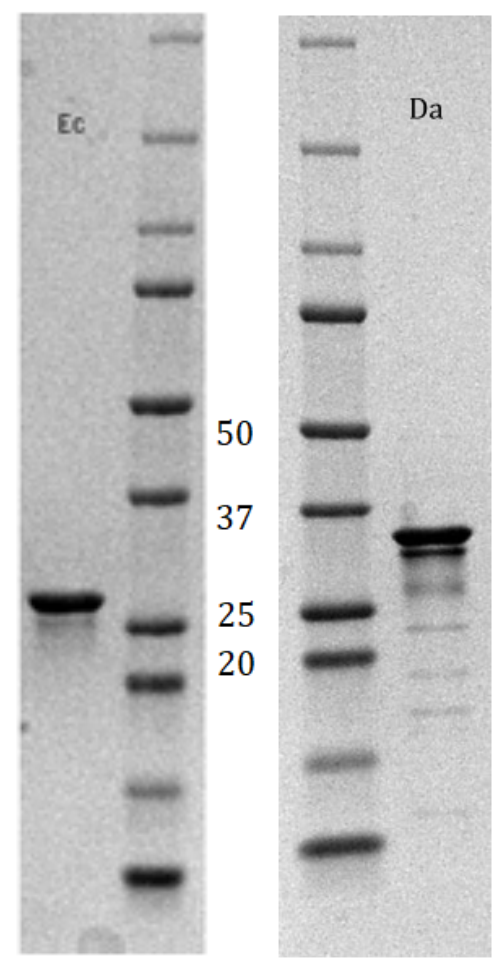

Fig. S5. CdtB from E. coli (Ec) and Dr. ananassae (Da) washed, separated by 10\% SDS-PAGE, and visualized by staining with Coomassie blue. Molecular mass markers are in kDa. 
Fig. S6
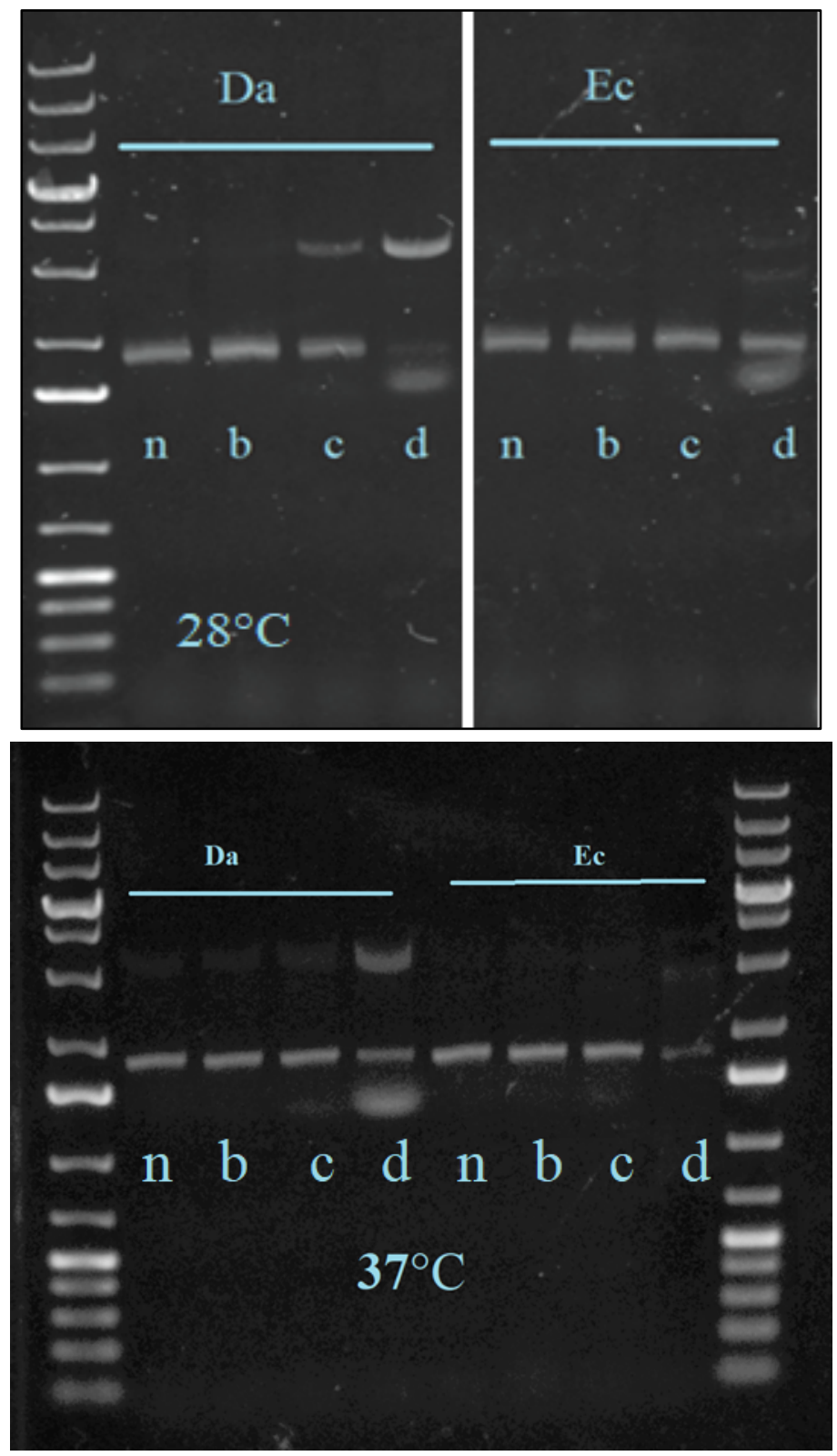

Fig S6. DNase activity assays of Dr. ananassae (Da) cdtB and E. coli (Ec) cdtB for 2 hours at two different temperatures, $28^{\circ} \mathrm{C}$ and $37^{\circ} \mathrm{C}$. $\mathrm{n}=$ buffer control (no cdtB), $\mathrm{b}=0.02 \mu \mathrm{g} \mathrm{cdtB}, \mathrm{c}=$ $0.2 \mu \mathrm{g}$ cdtB, $d=2 \mu \mathrm{g}$ cdtB. $0.8 \%$ agarose $1 \mathrm{X}$ TBE gels were stained with $0.01 \%$ SYBR ${ }^{\mathrm{TM}}$ Safe. $5 \mu \mathrm{L}$ of O'Gene Ruler $1 \mathrm{~kb}$ Ladder (ThermoFisher) are in the first and last wells in the image. For clarity, the first image is stitched from two parts of the same gel, and this division is indicated by a white vertical line. There were otherwise no vertical manipulations or nonlinear adjustments. For information on incubation conditions refer to the Materials and Methods. 
Fig. S7.

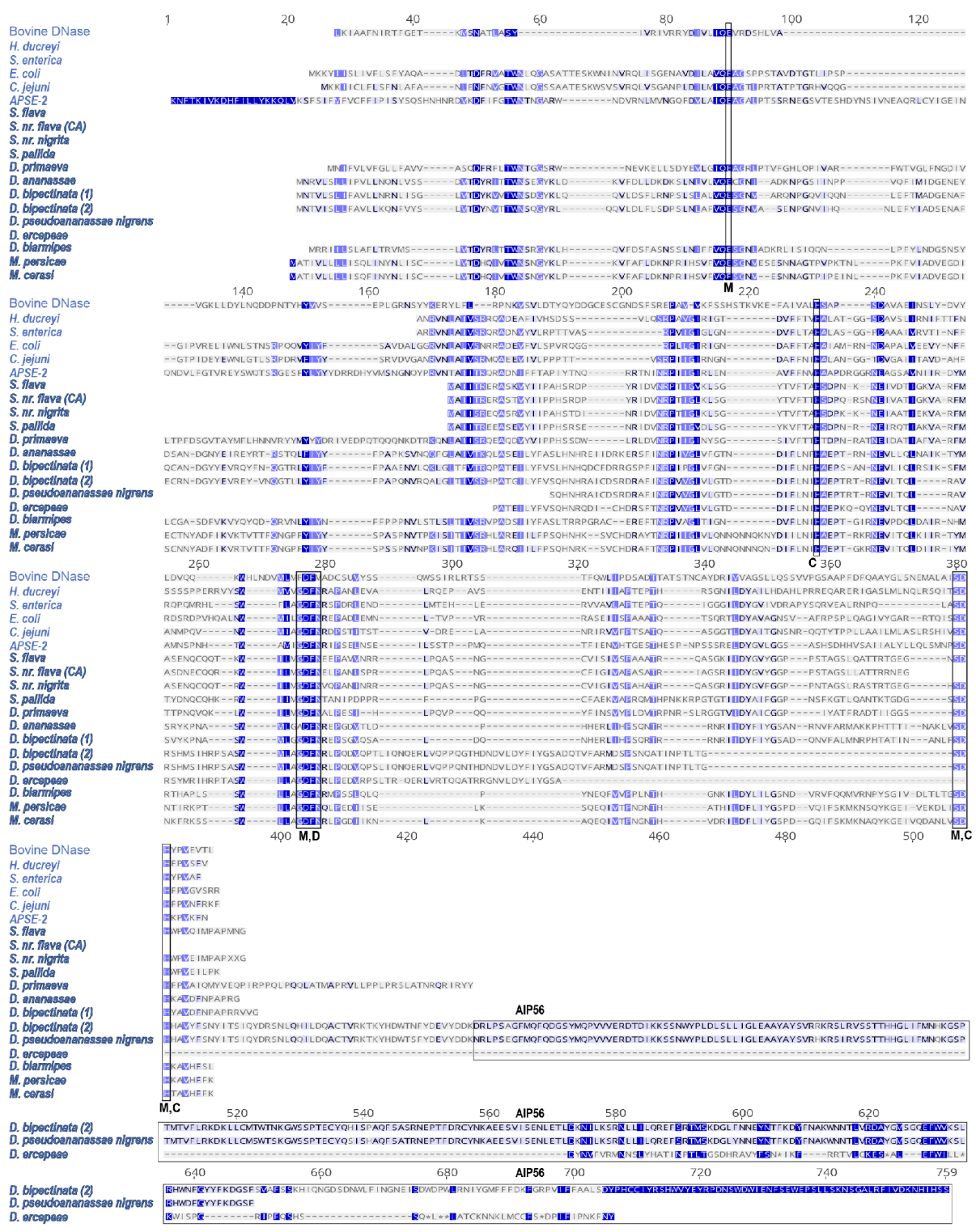

Fig. S7. MUSCLE alignment of cdtB from all identified eukaryotic species with non-

pseudogenized $c d t B$ copies. Vital DNase residues are highlighted in blue. Blue scale is based on BLOSUM62 similarity scores where darker residues are more similar. Bold species are eukaryotic. DNase and cdtB amino acid residues were from the following sources: Bovine DNase P00639, E. coli Q46669, C. jejuni A0A0E1ZJ81, S. enterica G5MJJ6, H. ducreyi G1UB80, APSE-2 C4K6T7, Dr. biarmipes XP_016950904.1, Dr. ananassae XP_014760894.1, Dr. bipectinata (1) XP_017099970.1, Dr. bipectinata (2) XP_017099943.1, M. persicae XP_022163116.1. Scaptomyza spp. and Dr. primaeva were translated from CDS in GenBank sequences MH884655-MH884659. Dr. pseudoananassae nigrens and Dr. ercepeae sequences were translated from sequences found from their transcriptomes (11). M. cerasi sequence acquisition is detailed in Methods. Residues vital for DNase activity are described in the main text. AIP56 domain is indicated in a black box. 
bioRxiv preprint doi: https://doi.org/10.1101/544197; this version posted February 9 2019. The copyright holder for this preprint (which was not certified by peer review) is the author/funder, who has granted bioRxiv a license to display the preprint in perpetuity. It is made available under aCC-BY-NC-ND 4.0 International license.

\section{Fig. S8.}

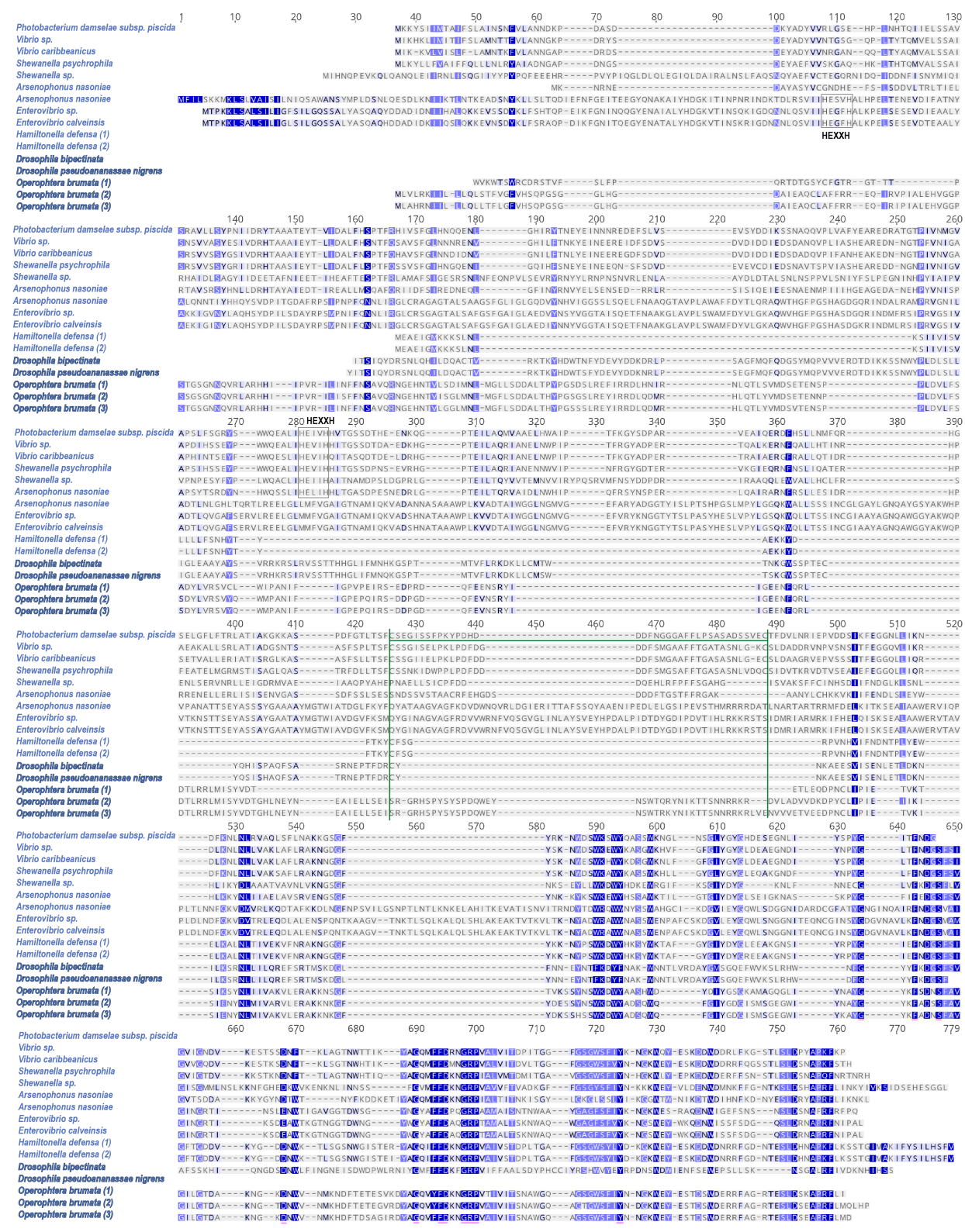

Fig. S8. MUSCLE alignment of aip56 from representative bacterial species and insect species. Bolded species re eukaryotic. Green borders indicate a disulfide bridge (green line) that separates the A (N-terminal) and B (C-terminal) domains. The HEXXH motif in bacterial species except $H$. defensa are boxed and labelled. Sequences were found from the following sources: $P$. damselae subsp. piscida: WP_094461508; Vibrio sp.: WP_089070319; Vibrio caribbeanicus: WP_009600485; Shewanella psychrophila: WP_07775466̄8; Shewanella sp.: WP_012326868; Arsenophonus nasoniae: WP_051297127, WP_051296919; Enterovibrio sp.: WP_102315974; Enterovibrio calviensis: WP_017014894; H. defensa $(1,2)$ : WP_015874047, WP_100096555, respectively; Dr. bipectinata 'tail': XP_017099943.1 residues 294-651; Dr. pseudoananassae nigrens: extracted and translated from (11); O. brumata $(1,2,3)$ : KOB68849, KOB69574, KOB68847, respectively. 
bioRxiv preprint doi: https://doi.org/10.1101/544197; this version posted February 9, 2019. The copyright holder for this preprint (which was not certified by peer review) is the author/funder, who has granted bioRxiv a license to display the preprint in perpetuity. It is made available under aCC-BY-NC-ND 4.0 International license.

Table S1. BLAST searches to the NCBI nr database were used to identify orthologs to $c d t B$ from $S$. flava. For Table S1a, the TBLASTX search was run using default settings with $S$. flava $c d t B$ as a query, which identified a $c d t B$ ortholog in Dr. bipectinata. In Table S1b, BLASTP search was run using the Dr. bipectinata cdtB ortholog (NCBI ID: XP_017099970.1) as a query.

Relevant matches are highlighted in purple with added description from authors in parentheses.

Table S1c presents positive TBLASTN output results from searching Myzus genomes and transcriptomes using $M$. persicae cdtB (NCBI ID: XP_022163116) and Ca. H. defensa cdtB (UniProt ID: C4K6T7) as queries.

Table Sla.

\begin{tabular}{|c|c|c|c|}
\hline Accession & Identity & E value & Total Score \\
\hline gi|669352722|gb|KFD82708.1| & 30.769 & $5.05 \mathrm{E}-15$ & 84.3 \\
\hline gi|694140751|ref|WP_032479052.1| & 30.256 & $5.38 \mathrm{E}-15$ & 84.3 \\
\hline 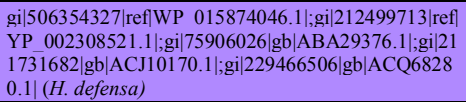 & 30.282 & $9.23 \mathrm{E}-14$ & 81.6 \\
\hline gi|548579396|gb|AGX01517.1| & 30.282 & $1.22 \mathrm{E}-13$ & 81.3 \\
\hline $\begin{array}{l}\text { gi|979475913|ref|WP_059330987.1|;gi|975193684|gb| } \\
\text { KUS12230.1| }\end{array}$ & 27.014 & $1.41 \mathrm{E}-13$ & 80.1 \\
\hline $\begin{array}{l}\text { gi|515335288||ref|WP_016857353.1|;gi|211731777|gb| } \\
\text { ACJ10107.1|;gi|807061167|emb|CED78233.1|;gi|123 } \\
9739342 \mid \text { gb|ASX26122.1| }\end{array}$ & 29.897 & $2.72 \mathrm{E}-12$ & 76.6 \\
\hline gi|1185521317|gb|OSJ40004.1| & 26.804 & $9.67 \mathrm{E}-12$ & 75.9 \\
\hline gi|1167649776|ref|WP_080070169.1| & 28.571 & $1.24 \mathrm{E}-11$ & 74.7 \\
\hline $\begin{array}{l}\text { gi|4876577777|ref|WP_001750060.1|;gi|459477644|gb| } \\
\text { EMG72218.1|;i||1185609746|gb|OSJ66146.1|;gi|1185 } \\
\text { 636954|gb|OSJ92077.1| }\end{array}$ & 31.731 & $1.72 \mathrm{E}-11$ & 74.3 \\
\hline $\begin{array}{l}\text { gi|981212232|reffWP_059435158.1|;gi|962432511|em } \\
\text { b|CUU80167.1| }\end{array}$ & 28.571 & $2.44 \mathrm{E}-11$ & 74.3 \\
\hline $\begin{array}{l}\text { gi|1041901932|ref|WP_065236386.1|;gi|1041834151| } \\
\text { gb|OBX05990.1| }\end{array}$ & 29.665 & $3.32 \mathrm{E}-11$ & 73.6 \\
\hline gi|1 160998720|ref|WP_079825120.1| & 32.161 & 7.37E-11 & 72.4 \\
\hline $\begin{array}{l}\text { gi|981206578|ref|WP_059429813.1|;gi|962416553|em } \\
\text { b|CUU68174.1| }\end{array}$ & 25.091 & $8.06 \mathrm{E}-11$ & 72.4 \\
\hline $\begin{array}{l}\text { gi|974630655|ref|WP_059217482.1|;gi|1221820570|d } \\
\text { bj|BBA13803.1| }\end{array}$ & 29.665 & $1.19 \mathrm{E}-10$ & 71.6 \\
\hline $\begin{array}{l}\text { gi|446682590|ref|WP_000759936.1|;gi|1221813739|d } \\
\text { bj|BBA13562.1| }\end{array}$ & 27.5 & $1.38 \mathrm{E}-10$ & 71.6 \\
\hline gi|260161890|dbj|BAI43479.1| & 27.143 & $1.72 \mathrm{E}-10$ & 71.2 \\
\hline 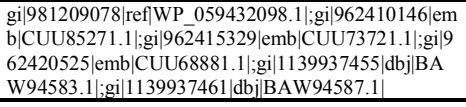 & 29.665 & $1.92 \mathrm{E}-10$ & 71.2 \\
\hline $\begin{array}{l}\text { gi|981209874|ref|WP_059432846.1|;gi|962428340|em } \\
\text { b|CUU68669.1| }\end{array}$ & 29.665 & $1.94 \mathrm{E}-10$ & 71.2 \\
\hline gi|1 10591317|pdb|2F1N|A & 29.187 & $2.56 \mathrm{E}-10$ & 70.9 \\
\hline $\begin{array}{l}\text { gi|974632782|ref|WP_059219457.1|;gi|1221813380|d } \\
\text { bj|BBA13547.1|;i|1221813388|dbj|BBA13550.1|;gi|1 } \\
221984755 \mid \text { dbj|BBA13532.1|;i||1221986235|db||BBA } \\
\text { 13538.1| }\end{array}$ & 26.978 & $3.67 \mathrm{E}-10$ & 70.5 \\
\hline gi|1067639108|dbj|BAV58431.1| & 26.978 & $3.99 \mathrm{E}-10$ & 70.5 \\
\hline gi|974639171|ref|WP_059225372.1| & 26.978 & 4.22E-10 & 70.1 \\
\hline $\begin{array}{l}\text { gi|1240311560|ref|WP_095574037.1|;gi|949422767|d } \\
\text { bj|BAT35603.1|;i|1221813773|dbj|BBA13574.1| }\end{array}$ & 27.143 & 4.51E-10 & 70.1 \\
\hline gi|1221813830|dbj|BBA13594.1| & 26.978 & $4.73 \mathrm{E}-10$ & 70.1 \\
\hline gi|380503729|dbj|BAL72684.1| & 26.978 & $4.78 \mathrm{E}-10$ & 70.1 \\
\hline
\end{tabular}


bioRxiv preprint doi: https://doi.org/10.1101/544197; this version posted February 9, 2019. The copyright holder for this preprint (which was not certified by peer review) is the author/funder, who has granted bioRxiv a license to display the preprint in perpetuity. It is made available under aCC-BY-NC-ND 4.0 International license.

\begin{tabular}{|c|c|c|c|}
\hline gi|239835498|dbj|BAH78179.1| & 26.882 & $4.91 \mathrm{E}-10$ & 70.1 \\
\hline gi|924626173|ref|WP_053530118.1| & 29.843 & $5.34 \mathrm{E}-10$ & 70.1 \\
\hline gi|754738927|ref|WP_042106220.1| & 28.061 & $5.59 \mathrm{E}-10$ & 70.1 \\
\hline $\begin{array}{l}\text { gi|1254454909|ref|WP_097308716.1|;gi|1221820576| } \\
\text { dbj|BBA13806.1|;gi|1261077766|gb|PFF93591.1| }\end{array}$ & 29.843 & $5.82 \mathrm{E}-10$ & 70.1 \\
\hline $\begin{array}{l}\text { gi|57012651|sp|Q46669.1|CDTB_ECOLX;gi|436946| } \\
\text { gb|AAA18786.1| }\end{array}$ & 29.843 & $5.87 \mathrm{E}-10$ & 69.7 \\
\hline $\begin{array}{l}\text { gi|1240313368|ref|WP_095575842.1|;gi|949427335|d } \\
\text { bj|BAT39876.1| }\end{array}$ & 26.978 & $5.95 \mathrm{E}-10$ & 69.7 \\
\hline $\begin{array}{l}\text { gi|974666766|ref|WP_059251177.1|;gi|1221813396|d } \\
\text { bj|BBA13553.1|;gi|1221813722|dbj|BBA13556.1|;gi|1 } \\
\text { 221813732|dbj|BBA13559.1|;gi|1221820559|dbj|BBA } \\
\text { 13797.1|;gi|1221820565|dbj|BBA13800.1| }\end{array}$ & 26.978 & $6.36 \mathrm{E}-10$ & 69.7 \\
\hline gi|962418376|emb|CUU85691.1| & 26.978 & $6.73 \mathrm{E}-10$ & 69.7 \\
\hline gi|981206168|ref|WP_059429417.1| & 29.665 & $6.83 \mathrm{E}-10$ & 69.3 \\
\hline $\begin{array}{l}\text { gi|740667214|ref|WP_038452504.1|;gi|669187494|gb| } \\
\text { AII13947.1|;gi|971186009|gb|ALV23685.1| }\end{array}$ & 29.665 & $7.45 \mathrm{E}-10$ & 69.3 \\
\hline gi|633260061|dbj|BAO79465.1| & 30.144 & $8.51 \mathrm{E}-10$ & 69.3 \\
\hline $\begin{array}{l}\text { gi|1186813941|ref|WP_085456383.1|;gi|1185798845| } \\
\text { gb|OSL33282.1| }\end{array}$ & 30.601 & $8.74 \mathrm{E}-10$ & 68.2 \\
\hline gi|974672910|ref|WP_059257174.1| & 26.619 & $1.06 \mathrm{E}-09$ & 68.9 \\
\hline gi|446657247|ref|WP_000734593.1 & 29.843 & $1.08 \mathrm{E}-09$ & 68.9 \\
\hline $\begin{array}{l}\text { gi|446657246|ref|WP_000734592.1|;gi|1185798633|g } \\
\text { b|OSL33070.1| }\end{array}$ & 29.843 & $1.09 \mathrm{E}-09$ & 68.9 \\
\hline gi|633260073|dbj|BAO79471.1| & 29.843 & $1.09 \mathrm{E}-09$ & 68.9 \\
\hline gi|1067639104|dbj|BAV58428.1| & 29.508 & $1.09 \mathrm{E}-09$ & 68.2 \\
\hline gi|633260069|dbj|BAO79469.1| & 29.843 & $1.14 \mathrm{E}-09$ & 68.9 \\
\hline gi|633260065|dbj|BAO79467.1| & 30.601 & $1.16 \mathrm{E}-09$ & 67.8 \\
\hline $\begin{array}{l}\text { gi|935476351|ref|WP_054412172.1|;gi|921494658|em } \\
\text { b|CTV99543.1|;gi|1221813371|dbj|BBA13544.1|;gi|1 } \\
\text { 221813754|dbj|BBA13568.1| }\end{array}$ & 30.601 & $1.24 \mathrm{E}-09$ & 67.8 \\
\hline $\begin{array}{l}\text { gi|446682591|ref|WP_000759937.1|;gi|52854784|gb| } \\
\text { AAU88264.1|;gi|52854791|gb|AAU88269.1|;gi|17012 } \\
\text { 1349|gb|EDS90280.1|;gi|569539448|gb|AHE61755.1|; } \\
\text { gi|689834862|dbj|GAL53245.1|;gi|1221813790|dbj|B } \\
\text { BA13580.1|;gi|1221813799|dbj|BBA13583.1|;gi|1221 } \\
\text { 813809|dbj|BBA13586.1|;gi|1221813818|dbj|BBA135 } \\
\text { 89.1|;gi|1261081802|gb|PFF97598.1| }\end{array}$ & 26.619 & $1.40 \mathrm{E}-09$ & 68.6 \\
\hline $\begin{array}{l}\text { gi|974650701|ref|WP_059236512.1|;gi|239793078|dbj } \\
\text { |BAH72965.1|;gi|953766046|dbj|BAT44166.1|;gi|122 } \\
\text { 1813747|dbj|BBA13565.1|;gi|1221813764|dbj|BBA13 } \\
571.1 \mid \text {;gi|1221813781|dbj|BBA13577.1|;gi|122198622 } \\
\text { 8|dbj|BBA13535.1|;gi|1221986241|dbj|BBA13541.1| }\end{array}$ & 26.786 & $1.57 \mathrm{E}-09$ & 68.6 \\
\hline gi|803451710|gb|KKB02544.1| & 26.619 & $1.58 \mathrm{E}-09$ & 68.6 \\
\hline $\begin{array}{l}\text { gi|919162880|ref|WP_052718511.1|;gi|585571036|gb| } \\
\text { AHJ58631.1|;gi|585571044|gb|AHJ58637.1|;gi|58557 } \\
\text { 1048|gb|AHJ58640.1|;gi|585571052|gb|AHJ58643.1|; } \\
\text { gi|585571056|gb|AHJ58646.1|;gi|585571060|gb|AHJ5 } \\
\text { 8649.1|;gi|585571064|gb|AHJ58652.1|;gi|585571068| } \\
\text { gb|AHJ58655.1|;gi|585571072|gb|AHJ58658.1| }\end{array}$ & 28.934 & $2.13 \mathrm{E}-09$ & 68.2 \\
\hline gi|974671417|ref|WP 059255682.1| & 28.934 & $2.16 \mathrm{E}-09$ & 68.2 \\
\hline $\begin{array}{l}\text { gi|545596271|ref|WP_021724663.1|;gi|523672810|em } \\
\text { b|CDG00158.1|;gi|585571040|gb|AHJ58634.1| }\end{array}$ & 26.619 & $2.21 \mathrm{E}-09$ & 68.2 \\
\hline gi|803448875|gb|KKA99832.1| & 28.934 & $2.29 \mathrm{E}-09$ & 68.2 \\
\hline $\begin{array}{l}\text { gi|1172292388|ref|WP_080675667.1|;gi|380503743|d } \\
\text { bj|BAL72697.1|;gi|573498779|gb|ETS99301.1|;gi|577 } \\
\text { 062157|gb|EUC99176.1| }\end{array}$ & 28.934 & $2.29 \mathrm{E}-09$ & 68.2 \\
\hline gi|1196481905|ref|WP_086143604.1| & 26.882 & $2.59 \mathrm{E}-09$ & 67.8 \\
\hline $\begin{array}{l}\text { gi|981211317|ref|WP_059434257.1|;gi|962409756|em } \\
\text { b|CUU74482.1|;gi|962423522|emb|CUU82063.1|;gi|1 } \\
\text { 139937448|dbj|BAW94578.1| }\end{array}$ & 27.885 & $2.59 \mathrm{E}-09$ & 67 \\
\hline gi|962426331|emb|CUU68708.1| & 29.187 & $2.61 \mathrm{E}-09$ & 67.8 \\
\hline
\end{tabular}


bioRxiv preprint doi: https://doi org/10.1101/544197; this version posted February 9 2019. The copyright holder for this preprint (which was not certified by peer review) is the author/funder, who has granted bioRxiv a license to display the preprint in perpetuity. It is made available under aCC-BY-NC-ND 4.0 International license.

\begin{tabular}{|c|c|c|c|}
\hline gi|981207587|ref|WP_059430808.1| & 29.187 & 2.67E-09 & 67.4 \\
\hline $\begin{array}{l}\text { gi|504817615|ref|WP_015004717.1|;gi|407240331|gb| } \\
\text { AFT90528.1| }\end{array}$ & 29.187 & $2.87 \mathrm{E}-09$ & 67.4 \\
\hline gi|1139937458|dbj|BAW94585.1| & 28.899 & $3.41 \mathrm{E}-09$ & 67.8 \\
\hline $\begin{array}{l}\text { gi|633260051|dbj|BAO79460.1|;gi|633260053|dbj|BA } \\
\text { O79461.1|;gi|633260057|dbj|BAO79463.1|;gi|633260 } \\
\text { 059|dbj|BAO79464.1|;gi|633260063|dbj|BAO79466.1 } \\
\end{array}$ & 29.187 & $3.47 \mathrm{E}-09$ & 67.4 \\
\hline $\begin{array}{l}\text { gi|633260049|dbj|BAO79459.1|;gi|633260055|dbj|BA } \\
\text { O79462.1| }\end{array}$ & 30.055 & $3.81 \mathrm{E}-09$ & 66.2 \\
\hline gi|633260047|dbj|BAO79458.1| & 30.055 & $4.80 \mathrm{E}-09$ & 66.2 \\
\hline gi|633260043|dbj|BAO79456.1| & 30.055 & 4.94E-09 & 66.2 \\
\hline gi|922008764|ref|WP_053294693.1| & 30.055 & 5.34E-09 & 65.9 \\
\hline gi|1172919822|ref|WP_080985521.1| & 29.843 & $5.81 \mathrm{E}-09$ & 67 \\
\hline gi|313128905|gb|EFR46522.1| & 32.192 & $6.96 \mathrm{E}-09$ & 67 \\
\hline gi|892368729|emb|CNB14664.1| & 29.952 & 7.33E-09 & 66.6 \\
\hline $\begin{array}{l}\text { gi|505266253|ref|WP_015453355.1|;gi|396078595|dbj } \\
\text { |BAM31971.1| }\end{array}$ & 32.192 & 7.39E-09 & 67 \\
\hline $\begin{array}{l}\text { gi|1205002136|ref|WP_087737881.1|;gi|1132092518| } \\
\text { emb|SIT48164.1| }\end{array}$ & 29.952 & $7.96 \mathrm{E}-09$ & 66.6 \\
\hline gi|1204938333|ref|WP_087687232.1| & 28.444 & 8.09E-09 & 66.6 \\
\hline gi|343381794|gb|AEM17342.1| & 28.856 & $1.06 \mathrm{E}-08$ & 66.2 \\
\hline $\begin{array}{l}\text { gi|504479811|ref|WP_014666913.1|;gi|385146935|dbj } \\
\text { |BAM12443.1| }\end{array}$ & 28.638 & $1.06 \mathrm{E}-08$ & 66.2 \\
\hline gi|295291384|gb|ADF87419.1| & 29.557 & $1.07 \mathrm{E}-08$ & 66.2 \\
\hline $\begin{array}{l}\text { gi|765033485|ref|WP_044599293.1|;gi|744807343|gb| } \\
\text { AJC85289.1| }\end{array}$ & 29.557 & $1.12 \mathrm{E}-08$ & 66.2 \\
\hline gi|1036995336|ref|XP_017099970.1| (D. bipectinata) & 29.851 & $1.14 \mathrm{E}-08$ & 65.9 \\
\hline
\end{tabular}

Table S1b.

\begin{tabular}{|c|c|c|c|}
\hline Accession & Identity & E-value & Total Score \\
\hline gi|1036995336|ref|XP_017099970.1| (D. bipectinata) & 100 & 0 & 587 \\
\hline $\begin{array}{l}\text { gi|964098914|ref|xp 014760894.|;gi|939214777|gb|KPU729 } \\
28.1 \mid \text { (D. ananassae) }\end{array}$ & 64.894 & $4.88 \mathrm{E}-129$ & 376 \\
\hline gi|1036994814|ref|XP_017099943.1| (D. bipectinata) & 65.714 & $2.76 \mathrm{E}-118$ & 362 \\
\hline gi|1036755562|ref|XP_016950904.1| (D. biarmipes) & 46.014 & $8.04 \mathrm{E}-63$ & 208 \\
\hline gi|1229885782|ref|XP_022163116.1| (Myzus persicae) & 40.69 & $3.31 \mathrm{E}-56$ & 191 \\
\hline $\begin{array}{l}\text { gi|565846545|ref|WP_023929546.1|;gi|564727729|gb| } \\
\text { ETD27707.1| }\end{array}$ & 28.053 & $2.10 \mathrm{E}-17$ & 89.7 \\
\hline $\begin{array}{l}\text { gi|493855940|reffWP_006802813.1|;gi|229376234|gb| } \\
\text { EEO26325.1| }\end{array}$ & 27.483 & $4.58 \mathrm{E}-17$ & 89 \\
\hline $\begin{array}{l}\text { gi|538019098|ref|WP_020995957.1|;gi }|534480459| \mathrm{gb} \mid \\
\text { EEO24760.2| }\end{array}$ & 26.073 & $2.76 \mathrm{E}-15$ & 84 \\
\hline $\begin{array}{l}\text { gi|490188257|ref|WP_004086857.1|;gi|476632580|gb| } \\
\text { EMZ39102.1|;gi|696178238|gb|KGL22057.1|;gi|69618 } \\
0431 \mid \text { |b||KGL24018.1| }\end{array}$ & 26.733 & $7.29 \mathrm{E}-15$ & 82.8 \\
\hline
\end{tabular}


bioRxiv preprint doi: https://doi.org/10.1101/544197; this version posted February 9, 2019. The copyright holder for this preprint (which was not certified by peer review) is the author/funder, who has granted bioRxiv a license to display the preprint in perpetuity. It is made available under aCC-BY-NC-ND 4.0 International license.

Table S1c.

\begin{tabular}{|c|c|c|c|c|c|c|c|c|c|c|}
\hline Database & $\begin{array}{l}\text { Query } \\
\text { Mpersica } \\
\text { e cdtB } \\
\text { protein } \\
\text { Hit name }\end{array}$ & $\begin{array}{l}\text { Leng } \\
\text { th of } \\
\text { hit }\end{array}$ & e-value & $\begin{array}{l}\text { Alignme } \\
\text { nt length }\end{array}$ & $\%$ identity & $\begin{array}{l}\text { Query } \\
\text { APSE-2 } \\
\text { cdtB } \\
\text { protein } \\
\text { Hit name }\end{array}$ & $\begin{array}{l}\text { Length } \\
\text { of hit }\end{array}$ & $\begin{array}{l}\text { e- } \\
\text { value }\end{array}$ & $\begin{array}{l}\text { Alignment } \\
\text { length }\end{array}$ & $\%$ identity \\
\hline $\begin{array}{l}\text { M. persicae } \\
\text { genome }\end{array}$ & $\begin{array}{l}\text { scaffold_ } \\
179\end{array}$ & $\begin{array}{l}5025 \\
01\end{array}$ & $1 \mathrm{e}-101$ & $\begin{array}{l}80,42,18 \\
1\end{array}$ & $\begin{array}{l}100 \%, 100 \%, 9 \\
6 \%\end{array}$ & $\begin{array}{l}\text { scaffold_1 } \\
79\end{array}$ & 502501 & $4 e-08$ & 112 & $34 \%$ \\
\hline $\begin{array}{l}\text { M. cerasi } \\
\text { genome }\end{array}$ & Mc971 & $\begin{array}{l}5230 \\
8\end{array}$ & $4 e-88$ & $\begin{array}{l}80,42,17 \\
1\end{array}$ & $\begin{array}{l}93 \%, 90 \%, 81 \\
\%\end{array}$ & Mc971 & 52308 & $2 \mathrm{e}-08$ & 105 & $35 \%$ \\
\hline $\begin{array}{l}\text { Di. noxia } \\
\text { genome }\end{array}$ & $\begin{array}{l}\text { JOTR01 } \\
000014\end{array}$ & $\begin{array}{l}1276 \\
361 \\
\end{array}$ & $2 \mathrm{e}-21$ & 75 & $67 \%$ & $\begin{array}{l}\text { No hits } \\
\text { found }\end{array}$ & N/A & N/A & N/A & $\mathrm{N} / \mathrm{A}$ \\
\hline \multirow[t]{4}{*}{$\begin{array}{l}\text { M. persicae } \\
\text { transcriptome }\end{array}$} & $\begin{array}{l}\text { TRINIT } \\
\text { Y_DN79 } \\
496 \_c 0- \\
\text { g1 i1 }\end{array}$ & 1950 & 0.0 & 292 & $100 \%$ & $\begin{array}{l}\text { TRINITY } \\
\text { DN79496_ } \\
\text { c0_g1_i1 }\end{array}$ & 1950 & $1 \mathrm{e}-12$ & 228 & $29 \%$ \\
\hline & $\begin{array}{l}\text { TRINIT } \\
\text { Y_DN79 } \\
496 \_c 0 \\
\text { g1_i2 }\end{array}$ & 1545 & $2 \mathrm{e}-109$ & 181 & $96 \%$ & $\begin{array}{l}\text { TRINITY } \\
\text { DN79496_ } \\
\text { c0_g1_i2 }\end{array}$ & 1545 & $2 \mathrm{e}-08$ & 112 & $34 \%$ \\
\hline & $\begin{array}{l}\text { TRINIT } \\
\text { Y_DN79 } \\
496 \_c 1- \\
\text { g1 il }\end{array}$ & 420 & $1 \mathrm{e}-88$ & 138 & $99 \%$ & $\begin{array}{l}\text { TRINITY } \\
\text { DN79496_ } \\
\text { c1_g1_i1 }\end{array}$ & 420 & $4 \mathrm{e}-04$ & 117 & $30 \%$ \\
\hline & $\begin{array}{l}\text { TRINIT } \\
\text { Y_DN14 } \\
6321 \text { c0 } \\
\text { g1 i1 }\end{array}$ & 270 & $2 e-41$ & 68 & $100 \%$ & N/A & & & & \\
\hline \multirow[t]{2}{*}{$\begin{array}{l}\text { M. cerasi } \\
\text { transcriptome }\end{array}$} & $\begin{array}{l}\text { TRINIT } \\
\text { Y_DN79 } \\
496 \_c 0 \\
\text { g1 il }\end{array}$ & 1462 & $6 e-174$ & 293 & $86 \%$ & $\begin{array}{l}\text { TRINITY } \\
\text { DN79496_ } \\
\text { c0_g1_i1 }\end{array}$ & 1462 & $2 e-12$ & 221 & $30 \%$ \\
\hline & $\begin{array}{l}\text { TRINIT } \\
\text { Y_DN79 } \\
496 \_c 0 \\
\text { g2 i2 }\end{array}$ & 1530 & $8 \mathrm{e}-133$ & 122,171 & $92 \%, 81 \%$ & $\begin{array}{l}\text { TRINITY } \\
\text { DN79496_ } \\
\text { c0_g2_i2 }\end{array}$ & 1530 & $5 e-09$ & 105 & $35 \%$ \\
\hline $\begin{array}{l}\text { Di. noxia } \\
\text { transcriptome }\end{array}$ & $\begin{array}{l}\text { No } \\
\text { significa } \\
\text { nt hits }\end{array}$ & N/A/ & N/A & N/A & N/A & $\begin{array}{l}\text { No } \\
\text { significant } \\
\text { hits }\end{array}$ & $\mathrm{N} / \mathrm{A}$ & $\mathrm{N} / \mathrm{A}$ & N/A & $\mathrm{N} / \mathrm{A}$ \\
\hline
\end{tabular}


bioRxiv preprint doi: https://doi.org/10.1101/544197; this version posted February 9, 2019. The copyright holder for this preprint (which was not certified by peer review) is the author/funder, who has granted bioRxiv a license to display the preprint in perpetuity. It is made available under aCC-BY-NC-ND 4.0 International license.

Table S2.

Details of genome assemblies and scaffolds from representative drosophilids or aphids in which $c d t B$ was identified.

\begin{tabular}{|c|c|c|c|c|c|}
\hline & Genome & $\begin{array}{l}\text { Genome } \\
\text { Scaffold } \\
\text { N50 } \\
\end{array}$ & $\begin{array}{l}\text { Genome } \\
\text { Coverage }\end{array}$ & Scaffold Size & Exons \\
\hline $\begin{array}{l}\text { Dr. } \\
\text { ananassae }\end{array}$ & GCA_000005115.1 & $4.59 \mathrm{Mb}$ & $8.9 \mathrm{X}$ & $\begin{array}{l}5.36 \mathrm{Mb} \\
\text { (NW_001939298) }\end{array}$ & 3 (GF26441) \\
\hline $\begin{array}{l}\text { Dr. } \\
\text { bipectinata }\end{array}$ & GCA_000233415.2 & $664 \mathrm{~kb}$ & $266.3 \mathrm{X}$ & $\begin{array}{l}732 \mathrm{~kb} \\
(\mathrm{~KB} 464254.1)\end{array}$ & 3 (LOC108127428) \\
\hline $\begin{array}{l}\text { Dr. } \\
\text { bipectinata }\end{array}$ & GCA_000233415.2 & $664 \mathrm{~kb}$ & $266.3 X$ & $\begin{array}{l}732 \mathrm{~kb} \\
(\mathrm{~KB} 464254.1)\end{array}$ & $5(\mathrm{LOC} 108127405)$ \\
\hline $\begin{array}{l}\text { Dr. } \\
\text { biarmipes }\end{array}$ & GCF_000233415.1 & $3.38 \mathrm{Mb}$ & $186.9 \mathrm{X}$ & $\begin{array}{l}3.95 \mathrm{Mb} \\
(\mathrm{KB} 462579.1)\end{array}$ & $3(\mathrm{LOC} 108025143)$ \\
\hline S. flava & RKRM00000000.1 & $105 \mathrm{~kb}$ & $90 \mathrm{X}$ & $1.4 \mathrm{Mb}$ & 1 \\
\hline $\begin{array}{l}\text { Dr. } \\
\text { primaeva }\end{array}$ & $\begin{array}{l}\text { Ellie Armstrong, } \\
\text { unpublished }\end{array}$ & $272 \mathrm{~kb}$ & $71.5 \mathrm{X}$ & $207 \mathrm{~kb}$ & $\begin{array}{l}\text { no transcriptome } \\
\text { data available }\end{array}$ \\
\hline $\begin{array}{l}\text { M. } \\
\text { persicae }\end{array}$ & GCF_001856785.1 & $435 \mathrm{~kb}$ & $200 X$ & $502 \mathrm{~kb}$ & $\begin{array}{r}3 \\
\left(\mathrm{XM} \_022307424.1\right)\end{array}$ \\
\hline
\end{tabular}

5 
bioRxiv preprint doi: https://doi.org/10.1101/544197; this version posted February 9, 2019. The copyright holder for this preprint (which was not certified by peer review) is the author/funder, who has granted bioRxiv a license to display the preprint in perpetuity. It is made available under aCC-BY-NC-ND 4.0 International license.

Table S3.

Primers used for PCR and RT-PCR. For associated gel images, please refer to Figure S1; for PCR conditions, please refer to Materials and Methods.

\begin{tabular}{|c|c|c|c|c|c|c|}
\hline \multirow[b]{2}{*}{ Name } & \multirow[b]{2}{*}{ Species } & \multicolumn{2}{|l|}{ Sequence $5 '-3$ ' } & \multirow[b]{2}{*}{$\operatorname{Tm}$ (Celsius) } & \multirow[b]{2}{*}{ Description } & \multirow[b]{2}{*}{ Gel image } \\
\hline & & Forward & Reverse & & & \\
\hline Sfla-Gen & S. flava & ACAACGCTGGCCTCAAGTAA & AGCCATTCATAGGAGCAGGC & 55 & $\begin{array}{l}\text { Genomic } \\
\text { amplification. } \\
\text { Includes parts } \\
\text { of } 5^{\prime} U T R \text { and } \\
\text { coding } \\
\text { sequence. }\end{array}$ & A \\
\hline Sfla-Coding & S. flava & ATGGCTATTATAACCCGTGA & CTGCTCCTATGAATGGCTAA & 55 & $\begin{array}{l}\text { Amplifies } \\
C d t B \text { from } \\
\text { start to stop } \\
\text { codon in } S . \\
\text { flava. Used for } \\
\text { cDNA } \\
\text { amplification. }\end{array}$ & $B, E, F$ \\
\hline Sfla-Upstream & S. flava & GGTGAGGGCAACAGTGATCA & TGCCTCGCCATGTTACACAT & 55 & $\begin{array}{l}\text { Amplifies } \\
\text { region } \sim 600 \text { bp } \\
\text { upstream of } \\
\text { CdtB coding } \\
\text { sequence in S. } \\
\text { flava. Includes } \\
\text { 5'UTR. }\end{array}$ & $\mathrm{B}, \mathrm{E}, \mathrm{F}$ \\
\hline $\begin{array}{l}\text { Sfla- } \\
\text { Downstream }\end{array}$ & S. flava & AAGCCAGCATCAGACAGCTT & TGTTTGGATCTGAGTGGGCC & 55 & $\begin{array}{l}\text { Amplifies } \\
\text { region } \sim 700 \text { bp } \\
\text { downstream of } \\
\text { CdtB coding } \\
\text { sequence in } S \text {. } \\
\text { flava. Includes } \\
3^{\prime} \text { UTR. }\end{array}$ & $\mathrm{A}, \mathrm{D}$ \\
\hline $\begin{array}{l}\text { Scaptomyza- } \\
\text { Intergenic }\end{array}$ & S. flava & CCGCATTGACAGTGCCTGCAAAA & AGGTGGACCGCCATAGACTCCAT & 64.1 & $\begin{array}{l}\text { Amplifies } \\
\sim 6 \mathrm{~kb} \\
\text { intergenic } \\
\text { segment } \\
\text { between } C d t B \\
\text { and closest } \\
\text { flanking gene } \\
\text { (dynamin-like } \\
\text { protein } 1) \text {. } \\
\text { Includes } \\
\text { portions of } \\
\text { these genes. }\end{array}$ & G \\
\hline Dana-Gen & D. ananassae & АTCTTTCACTGCCGGTACCG & TCTGACGCCAGTTGTTTGGT & 56 & $\begin{array}{l}\text { Spans } \sim 50 \mathrm{bp} \\
\text { upstream of } \\
\text { first exon to } \\
\text { beginning of } \\
\text { third exon. }\end{array}$ & $\mathrm{H}$ \\
\hline Dbia-Gen & D. biarmipes & ACCGACTACAGACTAACGACATG & AGCCTTGTGATCGGAACCTG & 57 & $\begin{array}{l}\text { Spans middle } \\
\text { of first exon to } \\
\text { near end of } \\
\text { third exon. }\end{array}$ & I \\
\hline Dbip-Coding1 & $\begin{array}{l}\text { D. bipectinata } \\
1\end{array}$ & CTGATTCGCGCGGAACAATG & СТАСТCTTCTTGGGGCAGGG & 56 & $\begin{array}{l}\text { Spans the } \\
\text { shorter } c d t B \\
\text { copy. Used for } \\
\text { RT-PCR. }\end{array}$ & J \\
\hline Dbip-Coding2 & $\begin{array}{l}\text { D. bipectinata } \\
2\end{array}$ & CACAAGGTTATAGACTACAG & CTTGGTAGCCTATCTTTATC & 46 & $\begin{array}{l}\text { Spans the } \\
\text { longer } c d t B \\
\text { copy from the } \\
\text { first to third } \\
\text { exon. Used for } \\
\text { RT-PCR. }\end{array}$ & $\mathrm{K}$ \\
\hline Spal-Coding & S. pallida & AGGAGGCCAGCGAGGTATACA & CACTGCTGCCGTCTCCAGTT & 53 & $\begin{array}{l}\text { Amplifies } \\
\text { coding } \\
\text { sequence of } \\
c d t B \text { in } S \text {. } \\
\text { pallida. }\end{array}$ & $\mathrm{L}$ \\
\hline $\begin{array}{l}\text { Dbip- } \\
\text { Coding2b }\end{array}$ & D. bipectinata & AGCTCCAATTGGTACCCGCT & AGCCAAGGATCCCAGTCGGA & 55 & $\begin{array}{l}\text { Spans the } \\
\text { longer } c d t B \\
\text { copy from the } \\
\text { third to fifth } \\
\text { exon. Used for } \\
\text { RT-PCR. }\end{array}$ & M \\
\hline
\end{tabular}




\section{Table S4.}

PacBio read alignment information for genes up and downstream of $c d t B$ in $S$. flava. Gene homology was determined via highest-confidence BLASTX (10) hits (default settings) using genes predicted from the $S$. flava genome. 'Proximity to $c d t B$ ' is negative if 5 ' of $c d t B$ and positive if 3' of $c d t B$. For example, a value of -4 indicates that the gene is four predicted genes upstream $\left(5^{\prime}\right)$ of $c d t B$. For more information, please refer to the main text.

\begin{tabular}{|c|c|c|c|c|c|c|}
\hline Name & $\begin{array}{l}\text { Proximity to } \\
c d t B\end{array}$ & Length & $\begin{array}{l}\text { Pairwise } \\
\% \text { identity }\end{array}$ & $\begin{array}{l}\text { Coverage } \\
\text { of all } \\
\text { bases }\end{array}$ & & BLASTX hit \\
\hline & & & & Mean & Stdev & \\
\hline$c d t B$ & 0 & 1139 & 72.7 & 10.4 & 0.8 & \\
\hline $\begin{array}{l}\text { maker-scaffold00004-augustus-gene- } \\
13.42\end{array}$ & 1 & 5120 & 74.8 & 5.9 & 1.4 & $\begin{array}{l}\text { PREDICTED: dynamin-1-like } \\
\text { protein isoform X2 [Drosophila } \\
\text { arizonae] }\end{array}$ \\
\hline $\begin{array}{l}\text { maker-scaffold00004-augustus-gene- } \\
13.46\end{array}$ & 2 & 573 & 92.4 & 5 & 0 & $\begin{array}{l}\text { PREDICTED: actin-related } \\
\text { protein } 2 / 3 \text { complex subunit } 5 \\
\text { [Drosophila eugracilis }]\end{array}$ \\
\hline $\begin{array}{l}\text { maker-scaffold00004-augustus-gene- } \\
13.43\end{array}$ & 3 & 823 & 87.4 & 4.5 & 0.5 & $\begin{array}{l}\text { PREDICTED: probably NADH } \\
\text { dehydrogenase [ubiquinone] } 1 \\
\text { alpha subcomplex subunit } 12 \\
\text { [Drosophila busckii] }\end{array}$ \\
\hline $\begin{array}{l}\text { augustus_masked-scaffold } 00004- \\
\text { processed-gene-13.11 }\end{array}$ & 4 & 1049 & 89 & 3.3 & 0.7 & $\begin{array}{l}\text { PREDICTED: early boundary } \\
\text { activity protien } 2 \text { [Drosophila } \\
\text { arizonae] }\end{array}$ \\
\hline $\begin{array}{l}\text { augustus_masked-scaffold00004- } \\
\text { processed-gene-13.6 }\end{array}$ & 5 & 1237 & 92.1 & 1.6 & 0.7 & $\begin{array}{l}\text { PREDICTED: protein } \\
\text { insensitive isoform X2 } \\
\text { [Drosophila arizonae] }\end{array}$ \\
\hline $\begin{array}{l}\text { maker-scaffold00004-augustus-gene- } \\
13.44\end{array}$ & 6 & 1976 & 81.5 & 3.9 & 0.3 & $\begin{array}{l}\text { PREDICTED: HCLS-1 } \\
\text { associated protein X-1 } \\
\text { [Tribolium castaneum }]\end{array}$ \\
\hline $\begin{array}{l}\text { maker-scaffold00004-augustus-gene- } \\
13.47\end{array}$ & 7 & 711 & 83.6 & 5.8 & 0.8 & $\begin{array}{l}\text { PREDICTED: NADH } \\
\text { dehydrogenase [ubiquinone] } \\
\text { iron-sulfur protein } 6, \\
\text { mitochondrial [Drosophila } \\
\text { ficusphila] }\end{array}$ \\
\hline $\begin{array}{l}\text { augustus_masked-scaffold00004- } \\
\text { processed-gene-13.8-mRNA-1 }\end{array}$ & -1 & 1264 & 76.4 & 13.9 & 0.6 & $\begin{array}{l}\text { PREDICTED: cilia- and } \\
\text { flagella-associated protein } 58 \\
\text { [Drosophila arizonae }]\end{array}$ \\
\hline $\begin{array}{l}\text { augustus_masked-scaffold00004- } \\
\text { processed-gene-13.3-mRNA-1 }\end{array}$ & -2 & 926 & 79.9 & 8.1 & 0.3 & $\begin{array}{l}\text { PREDICTED: GTP-binding } \\
\text { nuclear protein Ran-like } \\
{[\text { Drosophila busckii] }}\end{array}$ \\
\hline $\begin{array}{l}\text { augustus_masked-scaffold00004- } \\
\text { processed-gene-13.0-mRNA-1 }\end{array}$ & -3 & 1416 & 72.4 & 9.9 & 0.7 & $\begin{array}{l}\text { PREDICTED: casein kinase I } \\
\text { [Drosophila arizonae] }\end{array}$ \\
\hline $\begin{array}{l}\text { maker-scaffold00004-augustus-gene- } \\
\text { 13.45-mRNA-1 }\end{array}$ & -4 & 4397 & 75.1 & 10 & 1.8 & $\begin{array}{l}\text { PREDICTED: odorant } \\
\text { receptore 23a-like [Drosophila } \\
\text { busckii] }\end{array}$ \\
\hline $\begin{array}{l}\text { augustus_masked-scaffold } 00004 \text { - } \\
\text { processed-gene-12.9 }\end{array}$ & -5 & 2044 & 83.2 & 6.4 & 1.1 & $\begin{array}{l}\text { PREDICTED: TATA-box } \\
\text { binding protein-like protein } 1 \\
\text { [Drosophila bipectinata] }\end{array}$ \\
\hline
\end{tabular}




\section{Table S5.}

List of all drosophilid genomes (transcriptomes are included only if $c d t B$ was found) screened for evidence of $c d t B$. Genomes or transcriptomes were searched using TBLASTX with default options using $S$. flava, D. ananassae and $C a$. H. defensa $c d t B$ as queries. A liberal E-value of 0.0001 was the cutoff to consider a positive identification of $c d t B$. Species in which $c d t B$ was identified are highlighted in purple.

Accession numbers of genes used to construct the drosophilid species phylogeny are included. If no sequences were found on GenBank, the genomes (cited in the column labeled 'Reference') were searched using BLASTN (using the Dr. melanogaster gene sequence as a query) and the highest-confidence hit was used; in this case, the corresponding cells are marked 'genome'. If no sequences were found on GenBank or from searching the genome, the cell is highlighted yellow.

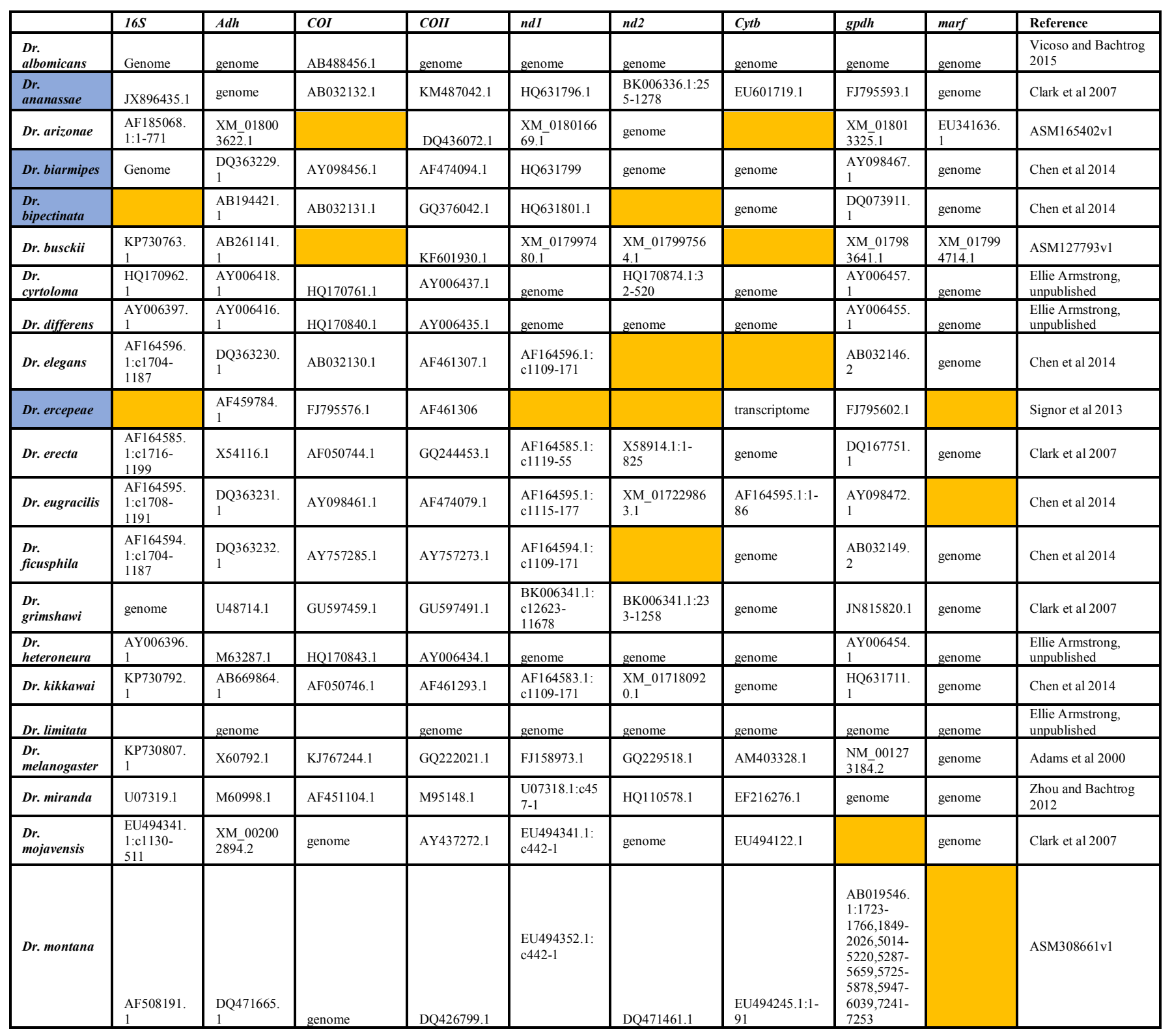


bioRxiv preprint doi: https://doi.org/10.1101/544197; this version posted February 9, 2019. The copyright holder for this preprint (which was not certified by peer review) is the author/funder, who has granted bioRxiv a license to display the preprint in perpetuity. It is made available under aCC-BY-NC-ND 4.0 International license.

\begin{tabular}{|c|c|c|c|c|c|c|c|c|c|c|}
\hline Dr. murphyi & genome & genome & genome & & & & & genome & & $\begin{array}{l}\text { Ellie Armstrong, } \\
\text { unpublished }\end{array}$ \\
\hline Dr. nasuta & $\begin{array}{l}\mathrm{AF} 387335 . \\
1\end{array}$ & $\begin{array}{l}\text { AB261137. } \\
1\end{array}$ & AB932738.1 & AB932783.1 & $\begin{array}{l}\text { EU494216.1: } \\
\text { c442-115 }\end{array}$ & $\begin{array}{l}\text { EU493589.1:1- } \\
271\end{array}$ & EU494105.1 & $\begin{array}{l}\text { AB261149. } \\
1\end{array}$ & $\begin{array}{l}\text { KX863731. } \\
1\end{array}$ & $\begin{array}{l}\text { Mohanty and Khanna } \\
2017\end{array}$ \\
\hline Dr. navojoa & $\begin{array}{l}\text { EU494342. } \\
1: c 1129- \\
511\end{array}$ & $\begin{array}{l}\text { AY156524. } \\
1\end{array}$ & genome & AY437285.1 & $\begin{array}{l}\text { XM_0181090 } \\
68.1\end{array}$ & from genome & EU494123.1 & & $\begin{array}{l}\text { EU341635. } \\
1\end{array}$ & ASM165401v1 \\
\hline $\begin{array}{l}\text { Dr. } \\
\text { novamexican } \\
\text { a }\end{array}$ & $\begin{array}{l}\text { AF508183. } \\
1\end{array}$ & $\begin{array}{l}\text { AY165542. } \\
1\end{array}$ & JF735929.1 & JF735934.1 & & genome & AY646768.1 & D50088.1 & & DnovRS1 \\
\hline Dr. obscura & U07303.1 & JF735883.1 & JF735919.1 & AF081356.1 & $\begin{array}{l}\text { U07302.1:c45 } \\
7-1\end{array}$ & EF216233.1 & EF216277.1 & & & Nozawa et al 2016 \\
\hline Dr. ochracea & $\begin{array}{l}\text { EU494395. } \\
1\end{array}$ & genome & genome & EU493797.1 & genome & genome & & genome & genome & $\begin{array}{l}\text { Ellie Armstrong, } \\
\text { unpublished }\end{array}$ \\
\hline $\begin{array}{l}\text { Dr. } \\
\text { paucipuncta }\end{array}$ & & genome & & & & genome & & genome & genome & $\begin{array}{l}\text { Ellie Armstrong, } \\
\text { unpublished }\end{array}$ \\
\hline Dr. persimilis & U07329.1 & $\begin{array}{l}\text { AF006564. } \\
1\end{array}$ & AF451101.1 & M95143.1 & $\begin{array}{l}\text { EU189432.1: } \\
\text { c893-147 }\end{array}$ & genome & EF216278.1 & $\begin{array}{l}\text { XM_00201 } \\
4220.1\end{array}$ & genome & Clark et al 2007 \\
\hline Dr. primaeva & $\begin{array}{l}\text { HQ170993. } \\
1\end{array}$ & $\begin{array}{l}\text { AY006426. } \\
1\end{array}$ & HQ170791.1 & AY006445.1 & genome & & genome & $\begin{array}{l}\text { AY006464. } \\
1\end{array}$ & genome & $\begin{array}{l}\text { Ellie Armstrong, } \\
\text { unpublished }\end{array}$ \\
\hline $\begin{array}{l}\text { Dr.. } \\
\text { prolaticilia }\end{array}$ & $\begin{array}{l}\text { HQ171040. } \\
1\end{array}$ & genome & HQ170837.1 & HQ170734 & genome & & & genome & genome & $\begin{array}{l}\text { Ellie Armstrong, } \\
\text { unpublished }\end{array}$ \\
\hline $\begin{array}{l}\text { Dr. } \\
\text { pseudoanana } \\
\text { ssae }\end{array}$ & $\begin{array}{l}\text { transcripto } \\
\text { me }\end{array}$ & $\begin{array}{l}\text { GQ376034. } \\
1\end{array}$ & AY757280.1 & AY757268.1 & HQ631820.1 & transcriptome & & & & Signor et al 2013 \\
\hline $\begin{array}{l}\text { Dr. } \\
\text { pseudoobscur } \\
\text { a }\end{array}$ & $\begin{array}{l}\text { EU494363. } \\
1: c 1131- \\
514\end{array}$ & X62214.1 & AF451087.1 & M95150.1 & $\begin{array}{l}\text { EU494363.1: } \\
\text { c442-1 }\end{array}$ & genome & EU494146 & & genome & Richards et al 2005 \\
\hline Dr. rhopaloa & genome & genome & genome & & genome & & genome & genome & genome & Drho_2.0 \\
\hline Dr. sechellia & $\begin{array}{l}\text { AF164589. } \\
1: c 1705- \\
1188\end{array}$ & X04672.1 & KJ425948.1 & GQ244458.1 & $\begin{array}{l}\text { AF164589.1: } \\
\text { c1109-171 }\end{array}$ & genome & $\begin{array}{l}\text { NC_005780.1:1 } \\
0535-11671\end{array}$ & genome & genome & Clark et al 2007 \\
\hline Dr. serrata & $\begin{array}{l}\text { AF164581. } \\
1: \text { C1710- } \\
1193 \\
\end{array}$ & $\begin{array}{l}\text { AB669879. } \\
1\end{array}$ & AB669749.1 & GQ376043.1 & $\begin{array}{l}\text { AF164581.1: } \\
\text { c1109-171 }\end{array}$ & $\begin{array}{l}\text { XM_02095456 } \\
5.1\end{array}$ & $\begin{array}{l}\text { AF164581.1:1- } \\
86\end{array}$ & $\begin{array}{l}\text { HQ631730. } \\
1\end{array}$ & & Allen et al 2017 \\
\hline Dr. simulans & $\begin{array}{l}\text { AF164588. } \\
1: \text { C } 1705- \\
1188\end{array}$ & X57362.1 & KX052973.1 & GQ222022.1 & $\begin{array}{l}\text { AF164588.1: } \\
\text { c1109-171 }\end{array}$ & genome & $\begin{array}{l}\text { JQ691661.1:10 } \\
\text { 528-11664 }\end{array}$ & $\begin{array}{l}\text { AF085163. } \\
1\end{array}$ & genome & Clark et al 2007 \\
\hline Dr. sproati & genome & genome & genome & $\mathrm{JX} 455050.1$ & genome & genome & genome & JN815748.1 & $\begin{array}{l}\text { KR270027. } \\
1\end{array}$ & $\begin{array}{l}\text { Ellie Armstrong, } \\
\text { unpublished }\end{array}$ \\
\hline Dr. suzukii & $\begin{array}{l}\text { KU588141. } \\
1: \text { C14068- } \\
12739\end{array}$ & $\begin{array}{l}\text { XM_01708 } \\
2035.1\end{array}$ & АВ032128.1 & LN867083.1 & HQ631827.1 & $\begin{array}{l}\text { XM_01707816 } \\
8.1\end{array}$ & $\begin{array}{l}\text { KU588141.1:1 } \\
0498-11634\end{array}$ & $\begin{array}{l}\text { AB032144. } \\
2\end{array}$ & & Chiu et al 2013 \\
\hline $\begin{array}{l}\text { Dr. } \\
\text { takahashii }\end{array}$ & $\begin{array}{l}\text { AF164592. } \\
1: \text { C1713- } \\
1196\end{array}$ & $\begin{array}{l}\text { KX384731. } \\
1\end{array}$ & KP863258.1 & AF474089.1 & $\begin{array}{l}\text { AF164592.1: } \\
\text { c1113-175 }\end{array}$ & $\begin{array}{l}\text { XM_01715533 } \\
9.1\end{array}$ & $\begin{array}{l}\text { AF164592.1:1- } \\
86\end{array}$ & $\begin{array}{l}\text { KR056774. } \\
1\end{array}$ & genome & Chen et al 2014 \\
\hline $\begin{array}{l}\text { Dr. } \\
\text { villosipedis }\end{array}$ & $\begin{array}{l}\text { HQ171042. } \\
1\end{array}$ & genome & HQ170839.1 & HQ170747.1 & genome & & & JN815717.1 & $\begin{array}{l}\text { KR269997. } \\
1\end{array}$ & $\begin{array}{l}\text { Ellie Armstrong, } \\
\text { unpublished }\end{array}$ \\
\hline Dr. virilis & $\begin{array}{l}\text { AF508180. } \\
1\end{array}$ & $\begin{array}{l}\text { DQ471668. } \\
1\end{array}$ & DQ426807.1 & HQ110559.1 & $\begin{array}{l}\text { EU494353.1: } \\
\text { c442-1 }\end{array}$ & & AY646772.1 & X59076.1 & genome & Clark et al 2007 \\
\hline Dr. willistoni & $\begin{array}{l}\text { EU494373. } \\
1: \text { C1111- } \\
495 \\
\end{array}$ & U95259.1 & KT194321.1 & HQ1 10560.1 & $\begin{array}{l}\text { EU494373.1: } \\
\text { c428-1 }\end{array}$ & $\begin{array}{l}\text { EU493643.1:1- } \\
271\end{array}$ & EU494155.1 & genome & genome & Clark et al 2007 \\
\hline Dr. yakuba & genome & $\begin{array}{l}\text { AY804555. } \\
1\end{array}$ & $\begin{array}{l}\text { X03240.1:1470 } \\
-3009\end{array}$ & $\begin{array}{l}\text { X03240.1:30 } \\
83-3766\end{array}$ & $\begin{array}{l}\mathrm{X} 03240.1: \mathrm{c} 12 \\
680-11706\end{array}$ & & $\begin{array}{l}\text { X03240.1:1051 } \\
\text { 5-11651 }\end{array}$ & $\begin{array}{l}\text { DQ167753. } \\
1\end{array}$ & & Clark et al 2007 \\
\hline $\begin{array}{l}\text { Scaptodrosop } \\
\text { hila } \\
\text { lebanonensis }\end{array}$ & $\begin{array}{l}\text { EU494411. } \\
1\end{array}$ & M97637.1 & EU493686.1 & HQ1 10572.1 & $\begin{array}{l}\text { EU494411.1: } \\
\text { c442-1 }\end{array}$ & HQ1 10598.1 & EU494188.1 & & & SlebRS1 \\
\hline $\begin{array}{l}\text { Scaptomyza } \\
\text { flava }\end{array}$ & $\begin{array}{l}\text { KC609621. } \\
1\end{array}$ & genome & JX160022.1 & HQ170738.1 & & KC609644.1 & genome & genome & JX160036.1 & RKRM00000000.1 \\
\hline $\begin{array}{l}\text { Scaptomyza } \\
\text { nigrita }\end{array}$ & $\begin{array}{l}\text { KC609624. } \\
1\end{array}$ & & $\mathrm{JX} 160025.1$ & JX160029 & & KC609647.1 & & & JX160039.1 & this study \\
\hline $\begin{array}{l}\text { Scaptomyza } \\
\text { pallida }\end{array}$ & $\begin{array}{l}\text { LC061488. } \\
1\end{array}$ & $\begin{array}{l}\text { AB033645. } \\
1\end{array}$ & KY847492.1 & HQ1 10571.1 & & HQ1 10597.1 & & $\begin{array}{l}\text { AB261157. } \\
1\end{array}$ & JX160037.1 & Gloss et al 2018 \\
\hline
\end{tabular}


Table S6.

Primers used for RT-qPCR including concentrations used, size of the amplicon, and efficiencies. For description of reaction and cycling conditions please refer to Methods.

\begin{tabular}{|c|c|c|c|c|c|c|}
\hline Species & Gene & $\mathbf{F}$ & $\mathbf{R}$ & $\begin{array}{l}\text { Primer } \\
\text { concentration } \\
(\mathrm{uM})\end{array}$ & $\begin{array}{l}\text { Size } \\
\text { (bp) }\end{array}$ & Efficiency \\
\hline $\begin{array}{l}\text { Dr. } \\
\text { ananassae }\end{array}$ & rpl32 & AAGCCCAAGGGTATCGACAA & GAACCGTAACCGATGTTGGG & 40 & 77 & 93 \\
\hline $\begin{array}{l}\text { Dr. } \\
\text { ananassae }\end{array}$ & $c d t B$ & TCACGCTGAACCCACTAGAA & GAAATCAGCGCCTAGCATCC & 60 & 109 & 111 \\
\hline S. flava & rpl32 & CAAGTTGTCGCACAAATGGC & GTGCGCTTGTTGGAACCATA & 40 & 91 & 98 \\
\hline S. flava & $c d t B$ & GCGGTCCACCTAGTACAGC & CAATGATCACTGTTGCCCTCAC & 40 & 69 & 92 \\
\hline
\end{tabular}

5 
bioRxiv preprint doi: https://doi.org/10.1101/544197; this version posted February 9,2019 . The copyright holder for this preprint (which was not certified by peer review) is the author/funder, who has granted bioRxiv a license to display the preprint in perpetuity. It is made available under aCC-BY-NC-ND 4.0 International license.

Table S7.

Mass spectrometry-based identification of the components of purified Dr. ananassae cdtB. '\# peptides' is equivalent to abundance of identified protein in purified $D r$. ananassae cdtB solution.

\begin{tabular}{|c|c|c|c|c|}
\hline Accession & Description & $\begin{array}{l}\text { MW } \\
{[\mathrm{kDa}]}\end{array}$ & calc. $p I$ & \# Peptides \\
\hline & Dr. ananassae cdtB & 33.1 & 8.53 & 54 \\
\hline C6EIY5 & $\begin{array}{l}\text { ATP-dependent RNA helicase OS=Escherichia coli (strain } \\
\text { B / BL21-DE3) GN=rhlE PE=3 SV=1 - } \\
\text { [C6EIY5 ECOBD] }\end{array}$ & 50 & 10.05 & 8 \\
\hline C6EGA6 & $\begin{array}{l}\text { CRP transcriptional dual regulator OS=Escherichia coli } \\
\text { (strain B / BL21-DE3) GN=crp PE=4 SV=1 - } \\
\text { [C6EGA6 ECOBD] }\end{array}$ & 23.6 & 8.25 & 8 \\
\hline С6ЕС08 & $\begin{array}{l}\text { 23S rRNA m1G745 methyltransferase OS=Escherichia coli } \\
\text { (strain B / BL21-DE3) GN=rrmA PE=4 SV=1 - } \\
\text { [C6EC08_ECOBD] }\end{array}$ & 30.4 & 7.5 & 7 \\
\hline C6EGY4 & $\begin{array}{l}\text { UPF0227 protein ycfP OS=Escherichia coli (strain B } / \\
\text { BL21-DE3) GN=ycfP PE=3 SV=1 - [C6EGY4 ECOBD }]\end{array}$ & 21.2 & 6.61 & 6 \\
\hline C6EA14 & $\begin{array}{l}\text { Pseudouridine synthase OS=Escherichia coli (strain B / } \\
\text { BL21-DE3) GN=rsuA PE=3 SV=1 - [C6EA14 ECOBD] }\end{array}$ & 25.8 & 6.18 & 5 \\
\hline C6EE23 & $\begin{array}{l}\text { Regulator of sigma D OS=Escherichia coli (strain B / } \\
\text { BL21-DE3) GN=rsd PE=3 SV=1 - [C6EE23_ECOBD] }\end{array}$ & 18.2 & 6.02 & 4 \\
\hline C6EJQ1 & $\begin{array}{l}\text { Ferric uptake regulator } \mathrm{OS}=\mathrm{Esch} \text { erichia coli }(\text { strain } \mathrm{B} / \\
\mathrm{BL} 21-\mathrm{DE} 3) \mathrm{GN}=\text { fur } \mathrm{PE}=4 \mathrm{SV}=1-[\mathrm{C} 6 \mathrm{EJQ1} E \mathrm{ECOBD}]\end{array}$ & 16.8 & 6.11 & 3 \\
\hline C6EH01 & $\begin{array}{l}\text { 50S ribosomal protein } \mathrm{L} 13 \mathrm{OS}=\text { Escherichia coli (strain B / } \\
\mathrm{BL} 21-\mathrm{DE} 3) \mathrm{GN}=\mathrm{rplM} \mathrm{PE}=3 \mathrm{SV}=1-[\mathrm{C} 6 \mathrm{EH} 01 \text { ECOBD }]\end{array}$ & 16 & 9.91 & 3 \\
\hline C6EHR2 & $\begin{array}{l}\text { Ribosomal RNA large subunit methyltransferase G } \\
\mathrm{OS}=\text { Escherichia coli (strain B / BL21-DE3) GN=ygjO } \\
\mathrm{PE}=3 \mathrm{SV}=1 \text { - [C6EHR2_ECOBD] }\end{array}$ & 42.3 & 6.8 & 2 \\
\hline C6EGB5 & $\begin{array}{l}\text { Peptidyl-prolyl cis-trans isomerase OS=Escherichia coli } \\
\text { (strain B / BL21-DE3) GN=slyD PE=4 SV=1 - } \\
\text { [C6EGB5 ECOBD] }\end{array}$ & 20.8 & 5.05 & 2 \\
\hline C6EGI7 & $\begin{array}{l}\text { Conserved protein OS=Escherichia coli (strain B / BL21- } \\
\text { DE3) GN=yrdA PE=4 SV=1 - [C6EGI7_ECOBD] }\end{array}$ & 20.2 & 5.53 & 2 \\
\hline C6EIF0 & $\begin{array}{l}\text { tRNA (guanine-N(7)-)-methyltransferase OS=Escherichia } \\
\text { coli (strain B / BL21-DE3) GN=yggH PE=3 SV=1 - } \\
\text { [C6EIF0_ECOBD] }\end{array}$ & 27.3 & 6.92 & 1 \\
\hline C6EKI9 & $\begin{array}{l}\text { Alpha-2-macroglobulin domain protein OS=Escherichia } \\
\text { coli (strain B / BL21-DE3) GN=yfhM } \mathrm{PE}=4 \mathrm{SV}=1 \text { - } \\
\text { [C6EKI9_ECOBD] }\end{array}$ & 181.4 & 5.43 & 1 \\
\hline
\end{tabular}


Table S8.

BLASTP results identifying the Dr. bipectinata cdtB + aip56 fusion. Results in eukaryotic species are indicated with an asterisk. A. BLASTP results from Dr. bipectinata non-alignable cdtB residues (residues 294-651 from XP_017099943.1) suggest homology to apoptosis inducing protein 56 (aip56). B. BLASTP results from $\mathrm{Ca}$. H. defensa ORF D.

Table S8a.

\begin{tabular}{|l|l|l|l|}
\hline Description & E-value & Identity & Accession \# \\
\hline $\begin{array}{l}\text { PREDICTED: uncharacterized protein LOC108127405 } \\
\text { [Drosophila bipectinata] }\end{array}$ & 0 & & \\
\hline $\begin{array}{l}\text { hypothetical protein [Candidatus Hamiltonella defensa] } \\
\text { hypothetical protein [Candidatus Hamiltonella defensa] }\end{array}$ & $1.06 \mathrm{E}-08$ & 32.075 & WP_015874047.1 \\
\hline Apoptosis inducing protein [Operophtera brumata] & $1.65 \mathrm{E}-08$ & 32.075 & WP_100096555.1 \\
\hline Aip56 [Danaus plexippus plexippus] * & $4.85 \mathrm{E}-05$ & 28.497 & KOB68847.1 \\
\hline hypothetical protein [Vibrio sp. 2521-89] & $9.54 \mathrm{E}-05$ & 29.012 & OWR44524.1 \\
\hline $\begin{array}{l}\text { hypothetical protein [Vibrio sp. 2017V-1085] } \\
\text { hypothetical protein [Vibrio sp. 2015V-1076] }\end{array}$ & $1.81 \mathrm{E}-04$ & 26.396 & WP_089070319.1 \\
\hline MULTISPECIES: hypothetical protein [Vibrio] & $3.05 \mathrm{E}-04$ & 25.888 & WP_113602841.1 \\
\hline hypothetical protein [Vibrio sp. HI00D65] & $3.16 \mathrm{E}-04$ & 25.888 & WP_113597563.1 \\
\hline hypothetical protein [Vibrio sp. 2017V-1070] & $3.30 \mathrm{E}-04$ & 25.888 & WP 113604820.1 \\
\hline hypothetical protein [Arsenophonus nasoniae] & $3.42 \mathrm{E}-04$ & 28.571 & WP 063524616.1 \\
\hline
\end{tabular}

\section{Table S8b.}

\begin{tabular}{|c|c|c|c|}
\hline Description & E-value & Identity & Accession \# \\
\hline hypothetical protein [Candidatus Hamiltonella defensa] & 0 & 100 & WP 015874047.1 \\
\hline hypothetical protein [Candidatus Hamiltonella defensa] & $1.21 \mathrm{E}-180$ & 98.819 & WP_100096555.1 \\
\hline hypothetical protein [Vibrio caribbeanicus] & $6.94 \mathrm{E}-68$ & 61.78 & WP_009600485.1 \\
\hline hypothetical protein [Vibrio sp.] & $2.93 \mathrm{E}-67$ & 59.259 & WP_113602841.1 \\
\hline hypothetical protein [Vibrio sp.] & $3.41 \mathrm{E}-67$ & 59.259 & WP_113597563.1 \\
\hline hypothetical protein [Vibrio sp.] & 4.04E-67 & 59.259 & WP_113604820.1 \\
\hline hypothetical protein [Vibrio sp.] & $5.06 \mathrm{E}-67$ & 59.259 & WP 113592639.1 \\
\hline hypothetical protein [Vibrio sp.] & $6.06 \mathrm{E}-67$ & 59.788 & WP_089070319.1 \\
\hline hypothetical protein [Vibrio sp.] & $8.02 \mathrm{E}-66$ & 60.847 & WP 009841419.1 \\
\hline hypothetical protein [Vibrio sp.] & $1.90 \mathrm{E}-65$ & 59.474 & WP_104037599.1 \\
\hline hypothetical protein [Vibrio sp.] & 4.24E-64 & 55.208 & WP 021710670.1 \\
\hline hypothetical protein [Vibrio sp.] & $3.45 \mathrm{E}-63$ & 54.45 & WP_063524616.1 \\
\hline hypothetical protein [Vibrio sp.] & $1.90 \mathrm{E}-62$ & 54.45 & WP 102424773.1 \\
\hline hypothetical protein [Vibrio sp.] & $2.32 \mathrm{E}-62$ & 54.45 & WP_105025149.1 \\
\hline hypothetical protein [Vibrio sp.] & 2.64E-62 & 54.45 & WP_102350207.1 \\
\hline hypothetical protein [Vibrio sp.] & 2.69E-62 & 54.45 & WP_102413802.1 \\
\hline hypothetical protein [Vibrio sp.] & $2.69 \mathrm{E}-62$ & 55.866 & WP_039981518.1 \\
\hline hypothetical protein [Vibrio sp.] & $2.72 \mathrm{E}-62$ & 54.45 & WP_017104811.1 \\
\hline hypothetical protein [Vibrio sp.] & $2.84 \mathrm{E}-62$ & 54.45 & WP 102459559.1 \\
\hline
\end{tabular}


bioRxiv preprint doi: https://doi.org/10.1101/544197; this version posted February 9, 2019. The copyright holder for this preprint (which was not certified by peer review) is the author/funder, who has granted bioRxiv a license to display the preprint in perpetuity. It is made available under aCC-BY-NC-ND 4.0 International license.

\begin{tabular}{|c|c|c|c|}
\hline hypothetical protein [Vibrio sp.] & $3.06 \mathrm{E}-62$ & 54.45 & WP 102276947.1 \\
\hline hypothetical protein [Vibrio sp.] & $3.41 \mathrm{E}-62$ & 54.45 & WP_032554400.1 \\
\hline non-LEE encoded type III effector C [Arsenophonus nasoniae] & $1.12 \mathrm{E}-61$ & 50.698 & CBA76058.1 \\
\hline hypothetical protein [Arsenophonus nasoniae] & $2.40 \mathrm{E}-61$ & 56.452 & WP 051297188.1 \\
\hline hypothetical protein [Shewanella psychrophila] & 7.11E-56 & 58.659 & WP_077754668.1 \\
\hline Aip56 [Photobacterium damselae $]$ & $3.86 \mathrm{E}-55$ & 52.577 & WP 012954632.1 \\
\hline $\begin{array}{l}\text { apoptosis inducing protein [Photobacterium damselae subsp. } \\
\text { piscicida] }\end{array}$ & 4.30E-55 & 52.577 & BAF99004.1 \\
\hline hypothetical protein [Arsenophonus nasoniae] & $1.45 \mathrm{E}-48$ & 50.811 & WP_051296919.1 \\
\hline Aip56 [Danaus plexippus plexippus]* & $1.27 \mathrm{E}-44$ & 50 & OWR44524.1 \\
\hline Apoptosis inducing protein [Operophtera brumata]* & $1.02 \mathrm{E}-43$ & 51.163 & KOB68849.1 \\
\hline Apoptosis inducing protein [Operophtera brumata]* & $4.59 \mathrm{E}-43$ & 52.381 & KOB68847.1 \\
\hline Apoptosis inducing protein [Operophtera brumata $]^{*}$ & $1.41 \mathrm{E}-41$ & 50.595 & KOB69574.1 \\
\hline Aip56 [Danaus plexippus plexippus]* & 4.63E-38 & 47.191 & OWR45007.1 \\
\hline hypothetical protein [Arsenophonus nasoniae] & $3.53 \mathrm{E}-32$ & 40.201 & WP 051297127.1 \\
\hline Apoptosis inducing protein [Operophtera brumata]* & $8.71 \mathrm{E}-25$ & 42.949 & KOB51764.1 \\
\hline hypothetical protein [Enterovibrio calviensis] & $2.68 \mathrm{E}-16$ & 36.216 & WP_017014894.1 \\
\hline hypothetical protein [Enterovibrio calviensis] & $2.79 \mathrm{E}-16$ & 36.216 & WP 017015789.1 \\
\hline MULTISPECIES: hypothetical protein [Enterovibrio] & $2.87 \mathrm{E}-16$ & 36.216 & WP 017009152.1 \\
\hline hypothetical protein [Enterovibrio norvegicus] & $6.29 \mathrm{E}-16$ & 35.676 & WP_102315974.1 \\
\hline hypothetical protein [Enterovibrio norvegicus] & $8.76 \mathrm{E}-16$ & 35.676 & WP 102390145.1 \\
\hline hypothetical protein [Enterovibrio norvegicus] & $9.18 \mathrm{E}-16$ & 35.676 & WP_102395244.1 \\
\hline hypothetical protein [Photobacterium damselae] & $5.85 \mathrm{E}-15$ & 47.778 & WP 094461508.1 \\
\hline hypothetical protein [Enterovibrio norvegicus] & $1.22 \mathrm{E}-14$ & 34.054 & WP_016961832.1 \\
\hline hypothetical protein [Enterovibrio norvegicus] & $1.28 \mathrm{E}-14$ & 34.054 & WP_017006435.1 \\
\hline MULTISPECIES: hypothetical protein [Shewanella] & $8.30 \mathrm{E}-12$ & 32.515 & WP 012326868.1 \\
\hline $\begin{array}{l}\text { PREDICTED: uncharacterized protein LOC } 108127405 \\
\text { [Drosophila bipectinata]* }\end{array}$ & $1.02 \mathrm{E}-08$ & 31.447 & XP_017099943.1 \\
\hline $\begin{array}{l}\text { hypothetical protein VIBC2010_06069 [Vibrio caribbeanicus } \\
\text { ATCC BAA-2122] }\end{array}$ & $6.92 \mathrm{E}-06$ & 48.889 & EFP97680.1 \\
\hline
\end{tabular}


bioRxiv preprint doi: https://doi.org/10.1101/544197; this version posted February 9, 2019. The copyright holder for this preprint (which was not certified by peer review) is the author/funder, who has granted bioRxiv a license to display the preprint in perpetuity. It is made available under aCC-BY-NC-ND 4.0 International license.

Table S9.

Microsyntenic analysis of genes immediately up and downstream of $c d t B$ in representative drosophilid species. Genes were determined in FlyBase (Dr. ananassae), from Chen et. al. 2014 (85) (Dr. bipectinata and Dr. biarmipes), the unpublished S. flava genome, or Mathers et. al. 2017 (41). Homology of up and downstream genes was predicted via default BLASTX searches using genes of interest as queries. 'Proximity to $c d t B$ ' is described in Table S4.

Synteny between the aphid species is supported by macrosyntenic analysis (see

\section{Supplementary Text).}

\begin{tabular}{|c|c|c|c|c|c|c|}
\hline & D. ananassae & & D. bipectinata & & D. biarmipes & \\
\hline $\begin{array}{l}\text { Proximity } \\
\text { to } c d t B\end{array}$ & FlyBase ID & Predicted Homolog & Accession \# & $\begin{array}{l}\text { Predicted } \\
\text { Homolog }\end{array}$ & Accession \# & Predicted Homolog \\
\hline-5 & $\begin{array}{l}\text { Dana/GF228 } \\
76\end{array}$ & $\begin{array}{l}\text { Mitotic checkpoint } \\
\text { protein BUB33. Has a } \\
\text { dual function in spindle- } \\
\text { assembly checkpoint } \\
\text { signaling and in } \\
\text { promoting the } \\
\text { establishment of correct } \\
\text { kinetochore- } \\
\text { microtubule (K-MT) } \\
\text { attachments. Promotes } \\
\text { the formation of stable } \\
\text { end-on bipolar } \\
\text { attachments. }\end{array}$ & $\begin{array}{l}\text { LOC108127480/XP_01 } \\
7100063.1\end{array}$ & $\begin{array}{l}\text { Mitotic } \\
\text { checkpoint } \\
\text { protein BUB3. } \\
\text { Has a dual } \\
\text { function in } \\
\text { spindle-assembly } \\
\text { checkpoint } \\
\text { signaling and in } \\
\text { promoting the } \\
\text { establishment of } \\
\text { correct } \\
\text { kinetochore- } \\
\text { microtubule (K- } \\
\text { MT) attachments. } \\
\text { Promotes the } \\
\text { formation of stable } \\
\text { end-on bipolar } \\
\text { attachments. }\end{array}$ & $\begin{array}{l}\text { LOC108025083/XP } \\
016950831.1\end{array}$ & $\begin{array}{l}\text { tRNA (adenine(58)- } \\
\text { N(1))- } \\
\text { methyltransferase } \\
\text { catalytic subunit } \\
\text { TRMT61A. Belongs to } \\
\text { family of transferases } \\
\text { transferring one-carbon } \\
\text { group } \\
\text { methyltransferases. }\end{array}$ \\
\hline-4 & $\begin{array}{l}\text { Dana/GF228 } \\
75\end{array}$ & $\begin{array}{l}\text { Lysoplasmalogenase- } \\
\text { like protein } \\
\text { TMEM86A. Enzyme } \\
\text { catalyzing the } \\
\text { degradation of } \\
\text { lysoplasmalogen, which } \\
\text { are formed by the } \\
\text { hydrolysis of the } \\
\text { abundant membrane } \\
\text { glycerophospholipids } \\
\text { plasmalogens. May } \\
\text { control respective level } \\
\text { of plasmalogens and } \\
\text { lysoplasmalogens in } \\
\text { cells and modulate cell } \\
\text { membrane properties. }\end{array}$ & $\begin{array}{l}\text { LOC108127421/XP_01 } \\
7099965.1\end{array}$ & $\begin{array}{l}\text { Lysoplasmalogen } \\
\text { ase-like protein } \\
\text { TMEM86A. } \\
\text { Enzyme catalyzing } \\
\text { the degradation of } \\
\text { lysoplasmalogen, } \\
\text { which are formed } \\
\text { by the hydrolysis } \\
\text { of the abundant } \\
\text { membrane } \\
\text { glycerophospholipi } \\
\text { ds plasmalogens. } \\
\text { May control } \\
\text { respective level of } \\
\text { plasmalogens and } \\
\text { lysoplasmalogens } \\
\text { in cells and } \\
\text { modulate cell } \\
\text { membrane } \\
\text { properties. }\end{array}$ & $\begin{array}{l}\text { LOC108025084/XP } \\
016950832.1\end{array}$ & $\begin{array}{l}\text { Uncharacterized } \\
\text { protein. Has predicted } \\
\text { KIAA1430 superfamily } \\
\text { domain. }\end{array}$ \\
\hline-3 & $\begin{array}{l}\text { Dana/GF233 } \\
59\end{array}$ & $\begin{array}{l}\text { Head-specific } \\
\text { guanylate cyclase. May } \\
\text { have a role in } \\
\text { phototransduction. } \\
\text { Molecular function: } \\
\text { GTP binding, guanylate } \\
\text { cyclase activity, heme } \\
\text { binding. cGMP } \\
\text { biosynthetic process, } \\
\text { intracellular signal } \\
\text { transduction, positive } \\
\text { phototaxis, rhodopsin } \\
\text { mediated signaling } \\
\text { pathway, visual } \\
\text { perception. }\end{array}$ & $\begin{array}{l}\text { LOC108127469/XP_01 } \\
700047.1\end{array}$ & $\begin{array}{l}\text { Head-specific } \\
\text { guanylate cyclase. } \\
\text { May have a role in } \\
\text { phototransduction. } \\
\text { Molecular } \\
\text { function: GTP } \\
\text { binding, guanylate } \\
\text { cyclase activity, } \\
\text { heme binding. } \\
\text { cGMP biosynthetic } \\
\text { process, } \\
\text { intracellular signal } \\
\text { transduction, } \\
\text { positive } \\
\text { phototaxis, } \\
\text { rhodopsin } \\
\text { mediated signaling } \\
\text { pathway, visual } \\
\text { perception. }\end{array}$ & $\begin{array}{l}\text { LOC108025050/XP } \\
016950796.1\end{array}$ & $\begin{array}{l}\text { Neuronal PAS } \\
\text { domain-containing } \\
\text { protein } 4 \text {. Required for } \\
\text { contextual memory in } \\
\text { the hippocampus. }\end{array}$ \\
\hline-2 & $\begin{array}{l}\text { Dana/Obp99 } \\
\text { c }\end{array}$ & $\begin{array}{l}\text { Odorant binding } \\
\text { protein. }\end{array}$ & $\begin{array}{l}\text { LOC10812740/XP_017 } \\
100048.1\end{array}$ & $\begin{array}{l}\text { General odorant- } \\
\text { binding protein } \\
\text { 99a }\end{array}$ & $\begin{array}{l}\text { LOC108025437/XP } \\
016951417.1\end{array}$ & $\begin{array}{l}\text { Suppressor protein } \\
\text { SRP40. Function not } \\
\text { known. }\end{array}$ \\
\hline
\end{tabular}


bioRxiv preprint doi: https://doi.org/10.1101/544197; this version posted February 9, 2019. The copyright holder for this preprint (which was not certified by peer review) is the author/funder, who has granted bioRxiv a license to display the preprint in perpetuity. It is made available under aCC-BY-NC-ND 4.0 International license.

\begin{tabular}{|c|c|c|c|c|c|c|}
\hline-1 & $\begin{array}{l}\text { Dana/GF233 } \\
61\end{array}$ & $\begin{array}{l}\text { Doublesex- and mab-3 } \\
\text { related transcription } \\
\text { factor A2. Protein } \\
\text { features are: DM DNA- } \\
\text { binding domain. } \\
\text { Molecular function is } \\
\text { described by: sequence- } \\
\text { specific DNA binding; } \\
\text { transcription factor } \\
\text { activity; sequence } \\
\text { specific DNA binding. }\end{array}$ & $\begin{array}{l}\text { LOC108127418/ } \\
\text { XP_017099960.1 }\end{array}$ & $\begin{array}{l}\text { Doublesex- and } \\
\text { mab-3 related } \\
\text { transcription } \\
\text { factor A2. Protein } \\
\text { features are: DM } \\
\text { DNA-binding } \\
\text { domain. } \\
\text { Molecular function } \\
\text { is described by: } \\
\text { sequence-specific } \\
\text { DNA binding; } \\
\text { transcription factor } \\
\text { activity; sequence } \\
\text { specific DNA } \\
\text { binding. }\end{array}$ & $\begin{array}{l}\text { LOC108025555/XP } \\
016951578.1\end{array}$ & $\begin{array}{l}\text { Uncharacterized } \\
\text { protein. Protein } \\
\text { features include: } \\
\text { FAD/NAD(P)-binding } \\
\text { domain; glucose- } \\
\text { methanol-choline } \\
\text { oxidoreductase. }\end{array}$ \\
\hline 0 & GF26441 & $c d t B$ & $\begin{array}{l}\text { LOC108127428 / } \\
\text { LOC108127405 } \\
\end{array}$ & $c d t B$ & LOC108025143 & cdt $B$ \\
\hline 1 & $\begin{array}{l}\text { Dana/Obp99 } \\
\text { d }\end{array}$ & $\begin{array}{l}\text { Odorant binding } \\
\text { protein. }\end{array}$ & $\begin{array}{l}\text { LOC108127413/XP_01 } \\
\text { 7099952.1 }\end{array}$ & $\begin{array}{l}\text { Odorant-binding } \\
\text { protein 99d }\end{array}$ & $\begin{array}{l}\text { LOC108025356/XP_ } \\
016951305.1\end{array}$ & $\begin{array}{l}\text { Uncharacterized } \\
\text { protein. }\end{array}$ \\
\hline 2 & $\begin{array}{l}\text { Dana/Obp99 } \\
\text { b-3 }\end{array}$ & $\begin{array}{l}\text { Odorant binding } \\
\text { protein. }\end{array}$ & $\begin{array}{l}\text { LOC108127412/XP_01 } \\
7099951.1\end{array}$ & $\begin{array}{l}\text { General odorant- } \\
\text { binding protein } \\
\text { 99b-like }\end{array}$ & $\begin{array}{l}\text { LOC108025355/XP } \\
016951303.1\end{array}$ & $\begin{array}{l}\text { Uncharacterized } \\
\text { protein. Contains } \\
\text { conserved protein } \\
\text { domain DUF3421, } \\
\text { which is found in the } \\
\text { fish toxin natterin and } \\
\text { other uncharacterized } \\
\text { proteins. }\end{array}$ \\
\hline 3 & $\begin{array}{l}\text { Dana/Obp99 } \\
\text { b-1 }\end{array}$ & $\begin{array}{l}\text { Odorant binding } \\
\text { protein. }\end{array}$ & $\begin{array}{l}\text { LOC108127419/XP_01 } \\
\text { 7099961.1 }\end{array}$ & $\begin{array}{l}\text { General odorant- } \\
\text { binding protein } \\
\text { 99b-like }\end{array}$ & $\begin{array}{l}\text { LOC108025354/XP } \\
016951302.1\end{array}$ & $\begin{array}{l}\text { HGH1. Predicted to be } \\
\text { involved in ribosome } \\
\text { biogenesis. }\end{array}$ \\
\hline 4 & $\begin{array}{l}\text { Dana/GF233 } \\
63\end{array}$ & $\begin{array}{l}\text { Calcium-binding } \\
\text { protein } P \text { isoform } X 1 \text {. }\end{array}$ & $\begin{array}{l}\text { LOC108127415/XP017 } \\
099958.1\end{array}$ & $\begin{array}{l}\text { Calcium-binding } \\
\text { protein P isoform } \\
\text { X2: proteins that } \\
\text { participate in } \\
\text { calcium cell } \\
\text { signaling pathways } \\
\text { by binding to } \\
\mathrm{Ca}++ \\
\end{array}$ & $\begin{array}{l}\text { LOC108025150/XP } \\
016950914.1\end{array}$ & $\begin{array}{l}\text { Trypsin-1. Member of } \\
\text { the trypsin family of } \\
\text { serine proteases. }\end{array}$ \\
\hline 5 & $\begin{array}{l}\text { Dana/GF233 } \\
64\end{array}$ & $\begin{array}{l}\text { Uncharacterized } \\
\text { protein. }\end{array}$ & $\begin{array}{l}\text { LOC108127417/XP_01 } \\
7099959.1\end{array}$ & $\begin{array}{l}\text { Uncharacterized } \\
\text { protein. }\end{array}$ & $\begin{array}{l}\text { LOC108025146/XP } \\
016950911.1\end{array}$ & Trypsin alpha. \\
\hline
\end{tabular}

\begin{tabular}{|c|c|c|}
\hline & S. flava & \\
\hline $\begin{array}{l}\text { Genes up or } \\
\text { downstream } \\
\text { of } c d t B\end{array}$ & Annotation ID & Predicted Homolog \\
\hline-5 & $\begin{array}{l}\text { augustus_masked- } \\
\text { scaffold00004- } \\
\text { processed-gene- } \\
12.9\end{array}$ & $\begin{array}{l}\text { TATA-box binding protein-like protein } 1 \text {. Part of a } \\
\text { specialized transcription system that mediates the } \\
\text { transcription of most ribosomal proteins through } 5 \text { '-TCT- } \\
\text { 3' motif. }\end{array}$ \\
\hline-4 & $\begin{array}{l}\text { maker- } \\
\text { scaffold00004- } \\
\text { augustus-gene- } \\
13.45\end{array}$ & Odorant receptor 23a-like. \\
\hline-3 & $\begin{array}{l}\text { augustus masked- } \\
\text { scaffold00004- } \\
\text { processed-gene- } \\
13.0\end{array}$ & $\begin{array}{l}\text { Casein kinase I. Serine/threonine selective enzymes that } \\
\text { function as regulators of signal transduction pathways in } \\
\text { most eukaryotes. }\end{array}$ \\
\hline-2 & $\begin{array}{l}\text { augustus_masked- } \\
\text { scaffold00004- } \\
\text { processed-gene- } \\
13.3\end{array}$ & $\begin{array}{l}\text { GTP-binding nuclear protein Ran-like. GTP-binding } \\
\text { protein involved in nucleocytoplasmic transport. } \\
\text { Required for the import of protein into the nucleus and } \\
\text { also for RNA export. }\end{array}$ \\
\hline-1 & $\begin{array}{l}\text { augustus_masked- } \\
\text { scaffold00004- } \\
\text { processed-gene- } \\
13.8\end{array}$ & Cilia- and flagella-associated protein 58 . \\
\hline $\mathbf{0}$ & No annotation ID & $c d t B$ \\
\hline 1 & $\begin{array}{l}\text { maker- } \\
\text { scaffold00004- } \\
\text { augustus-gene- } \\
13.42\end{array}$ & $\begin{array}{l}\text { Dynamin-1-like protein. Functions in mitochondrial } \\
\text { and peroxisomal division. Required for normal rate of } \\
\text { cytochrome c release and caspase activation during } \\
\text { apoptosis. Required for formation of endocytic vesicles. }\end{array}$ \\
\hline
\end{tabular}


bioRxiv preprint doi: https://doi.org/10.1101/544197; this version posted February 9, 2019. The copyright holder for this preprint (which was not certified by peer review) is the author/funder, who has granted bioRxiv a license to display the preprint in perpetuity. It is made available under aCC-BY-NC-ND 4.0 International license.

\begin{tabular}{|l|l|l|}
\hline $\mathbf{2}$ & $\begin{array}{l}\text { maker- } \\
\text { scaffold00004- } \\
\text { augustus-gene- } \\
13.46\end{array}$ & $\begin{array}{l}\text { Actin-related protein 2/3 complex subunit 5. } \\
\text { Component of Arp2/3 complex which is involved in } \\
\text { regulation of actin polymerization and together with } \\
\text { activating nucleation-promoting factor mediates } \\
\text { formation of branched actin networks. }\end{array}$ \\
\hline $\mathbf{3}$ & $\begin{array}{l}\text { maker- } \\
\text { scaffold00004- } \\
\text { augustus-gene- } \\
13.43 \text {-mRNA-1 }\end{array}$ & $\begin{array}{l}\text { Probably NADH dehydrogenase [ubiquinone] 1 alpha } \\
\text { subcomplex subunit 12. Accessory subunit of the } \\
\text { mitochondrial membrane respiratory chain NADH } \\
\text { dehydrogenase. }\end{array}$ \\
\hline $\mathbf{4}$ & $\begin{array}{l}\text { Gloss et al 2018./ } \\
\text { augustus_masked- } \\
\text { scaffold00004- } \\
\text { processed-gene- } \\
13.11 /[1387264- \\
1388214]\end{array}$ & $\begin{array}{l}\text { Early boundary activity protein 2. Required for } \\
\text { chromatin domain boundary function during early } \\
\text { embryogenesis. }\end{array}$ \\
\hline $\mathbf{5}$ & $\begin{array}{l}\text { Gloss et al 2018./ } \\
\text { augustus_masked- } \\
\text { scaffold00004- } \\
\text { processed-gene- } \\
13.6-m R N A-1 / \\
{[1389880,1391098]}\end{array}$ & $\begin{array}{l}\text { Protein insensitive isoform X2. Can act as a } \\
\text { transcriptional repressor and corepressor. }\end{array}$ \\
\hline
\end{tabular}




\section{Supplementary References}

33. S. R. Eddy, A new generation of homology search tools based on probabilistic inference. Genome Inform. 23, 205-211 (2009).

34. K. Katoh, D. M. Standley, MAFFT multiple sequence alignment software version 7: Improvements in performance and usability. Mol. Biol. Evol. 30, 772-780 (2013).

35. S. Capella-Gutiérrez, J. M. Silla-Martínez, T. Gabaldón, trimAl: A tool for automated alignment trimming in large-scale phylogenetic analyses. Bioinformatics 25, 1972-1973 (2009).

36. M. Nguyen, A. Ekstrom, X. Li, Y. Yin, HGT-finder: A new tool for horizontal gene transfer finding and application to Aspergillus genomes. Toxins 7, 4035-4053 (2015).

37. E. Paradis, J. Claude, K. Strimmer, APE: Analyses of phylogenetics and evolution in R language. Bioinformatics 20, 289-290 (2004).

38. K. P. Schliep, phangorn: phylogenetic analysis in R. Bioinformatics. 27, 592-593 (2011).

39. I. Letunic, P. Bork, Interactive tree of life (iTOL) v3: an online tool for the display and annotation of phylogenetic and other trees. Nucleic Acids Res. 44, W242-W245 (2016).

40. E. Nováková, V. Hypsa, J. Klein, R. G. Foottit, C. D. von Dohlen, N. A. Moran, Reconstructing the phylogeny of aphids (Hemiptera: Aphididae) using DNA of the obligate symbiont Buchnera aphidicola. Mol. Phylogenet. Evol. 68, 42-54 (2013).

41. T. C. Mathers, Y. Chen, G. Kaithakottil, F. Legeai, S. T. Mugford, P. Baa-Puyoulet, A. Bretaudeau, B. Clavijo, S. Colella, O. Collin, T. Dalmay, Rapid transcriptional plasticity of duplicated gene clusters enables a clonally reproducing aphid to colonise diverse plant species. Genome Biol. 18, 1-20 (2017).

42. International Aphid Genomics Consortium, Genome sequence of the pea aphid Acyrthosiphon pisum. PLoS Biol. 8 (2010).

43. S. J. Nicholson, M. L. Nickerson, M. Dean, Y. Song, P. R. Hoyt, H. Rhee, C. Kim, G. J. Puterka, The genome of Diuraphis noxia, a global aphid pest of small grains. BMC Genomics 16, 1-16 (2015).

44. D. G. Miller, S. P. Lawson, D. C. Rinker, H. Estby, P. Abbot, The origin and genetic differentiation of the socially parasitic aphid Tamalia inquilinus. Mol. Ecol. 24, 57515766 (2015).

45. R. P. Duncan, H. Feng, D. M. Nguyen, A. C. C. Wilson, Gene family expansions in aphids maintained by endosymbiotic and nonsymbiotic traits. Genome Biol. Evol. 8, 753-764 (2016).

46. S. S. L. Birnbaum, D. C. Rinker, N. M. Gerardo, P. Abbot, Transcriptional profile and differential fitness in a specialist milkweed insect across host plants varying in toxicity. Mol. Ecol. 26, 6742-6761 (2017).

47. S. P. Lawson, L. T. Sigle, A. L. Lind, A. W. Legan, J. M. Mezzanotte, H. Honegger, P. Abbot, An alternative pathway to eusociality: Exploring the molecular and functional basis of fortress defense. Evolution 71, 1986-1998 (2017).

48. P. H. Degnan, Y. Yu, N. Sisneros, R. A. Wing, N. A. Moran, Hamiltonella defensa, genome evolution of protective bacterial endosymbiont from pathogenic ancestors. Proc. Natl. Acad. Sci. 106, 9063-9068 (2009).

49. H. Feng, L. Wang, S. Wuchty, A. C. C. Wilson, microRNA regulation in an ancient obligate endosymbiosis. Mol. Ecol. 27, 1777-1793 (2018).

50. M. G. Grabherr, B. J. Haas, M. Yassour, J. Z. Levin, D. A. Thompson, I. Amit, X. 
51. H. Li, R. Durbin, Fast and accurate shot read algnnen

Adiconis, L. Fan, R. Raychowdhury, Q. Zeng, Z. Chen, E. Mauceli, N. Hacohen, A. Gnirke, N. Rhind, F. di Palma, B. W. Birren, C. Nusbaum, K. Lindblad-Toh, N. Friedman, A. Regev, Trinity: reconstructing a full-length transcriptome without a genome from RNA-Seq data. Nat. Biotechnol. 29, 644-652 (2013). transform. Bioinformatics 25, 1754-1760 (2009).

52. A. Stamatakis, RAxML version 8: a tool for phylogenetic analysis and post-analysis of large phylogenies. Bioinformatics 30 1312-1313 (2014).

53. X. Zhou, X. X. Shen, C. T. Hittinger, A. Rokas, Evaluating fast maximum likelihoodbased phylogenetic programs using empirical phylogenomic data sets. Mol. Biol. Evol. 35, 486-503 (2018).

54. H. Shimodaira, M. Hasegawa, CONSEL: for assessing the confidence of phylogenetic tree selection. Bioinformatics 17, 1246-1247 (2001).

55. H. Shimodaira, An approximately unbiased test of phylogenetic tree selection. Syst. Biol.

56. R. C. Edgar, MUSCLE: Multiple sequence alignment with high accuracy and high throughput. Nucleic Acids Res. 32, 1792-1797 (2004).

57. M. Kearse, R. Moir, A. Wilson, S. Stones-Havas, M. Cheung, S. Sturrock, S. Buxton, A. Cooper, S. Markowitz, C. Duran, T. Thierer, B. Ashton, P. Meintjes, A. Drummond, Geneious Basic: An integrated and extendable desktop software platform for the organization and analysis of sequence data. Bioinformatics 28, 1647-1649 (2012).

58. K. Tamura, M. Nei, Estimation of the number of nucleotide substitutions in the control region of mitochondrial DNA in humans and chimpanzees. Mol Biol Evol. 10, 512-526 (1993).

59. L. J. Revell, phytools: An R package for phylogenetic comparative biology (and other things). Methods Ecol. Evol. 3, 217-223 (2012).

60. R. Development Core Team, R: A Language and Environment for Statistical Computing. 2.11.1 (2010), (available at http://www.r-project.org).

61. S. P. Bainbridge, M. Bownes, Staging the metamorphosis of Drosophila melanogaster. J. Embryol. Exp. Morphol. 66, 57-80 (1981).

62. M. W. Pfaffl, A new mathematical model for relative quantification in real-time RT-PCR. Nucleic Acids Res. 29, 2002-2007 (2001).

63. M. Z. Li, S. J. Elledge, SLIC: A Method for Sequence- and Ligation-independent cloning. Methods Mol. Biol. 852, 51-59 (2012).

64. L. Käll, A. Krogh, E. L. L. Sonnhammer, A combined transmembrane topology and signal peptide prediction method. J. Mol. Biol. 338, 1027-1036 (2004).

65. C. Q. Pan, R. A. Lazarus, Hyperactivity of Human DNase I Variants. Biochemistry. 273, 11701-11708 (1998).

66. D. Obradović, R. Gaspersic, S. Caserman, A. Leonardi, M. Jamnik, Z. Podlesek, K. Seme, G. Anderluh, I. Krizaj, P. Macek, M. Butala, A cytolethal distending toxin variant from Aggregatibacter actinomycetemcomitans with an aberrant CdtB that lacks the conserved catalytic histidine 160. PLoS One. 11, 1-16 (2016).

67. M. C. Thomas, C.-M. Chiang, The general transcription machinery and general cofactors. Crit. Rev. Biochem. Mol. Biol. 41, 105-178 (2006).

68. M. Kozak, An analysis of 5'-noncoding sequences from 699 vertebrate messenger RNAs. Nucleic Acids Res. 15, 8125-8148 (1987). 
69. M. Kozak, Pushing the limits of the scanning mechanism for initiation of translation. Gene 299, 1-34 (2002).

70. D. R. Cavener, Comparison of the consensus sequence flanking translational start sites in Drosophila and vertebrates. Nucleic Acids Res. 15, 1353-1361 (1987).

71. M. C. Blake, R. C. Jambou, A. G. Swick, J. W. Kahn, J. C. Azizkhan, Transcriptional initiation is controlled by upstream GC-box interactions in a TATAA-less promoter. Mol. Cell. Biol. 10, 6632-6641 (1990).

72. B. J. Graves, P. F. Johnson, S. L. McKnight, Homologous recognition of a promoter domain common to the MSV LTR and the HSV tk gene. Cell 44, 565-576 (1986).

73. M. Raymondjean, S. Cereghini, M. Yaniv, Several distinct "CCAAT" box binding proteins coexist in eukaryotic cells. Proc. Natl. Acad. Sci. 85, 757-61 (1988).

74. J. Shine, L. Dalgarno, The 3'-terminal sequence of Escherichia coli 16S ribosomal RNA: complementarity to nonsense triplets and ribosome binding sites. Proc. Natl. Acad. Sci. 71, 1342-1346 (1974).

75. N. J. Proudfoot, Ending the message: poly(A) signals then and now. Genes Dev. 25, 177082 (2011).

76. H. T. McMahon, I. G. Mills, COP and clathrin-coated vesicle budding: different pathways, common approaches. Curr. Opin. Cell Biol. 16, 379-391 (2004).

77. J. Sprenger, J. L. Fink, S. Karunaratne, K. Hnason, N. A. Hamilton, R. D. Teasdale, LOCATE: A mammalian protein subcellular localization database. Nucleic Acids Res. 36, 230-233 (2008).

78. J. Perez-Vilar, S. H. Randell, R. C. Boucher, C-mannosylation of MUC5AC and MUC5B Cys subdomains. Glycobiology. 14, 325-337 (2004).

79. J. S. Chauhan, A. H. Bhat, G. P. S. Raghava, A. Rao, GlycoPP: A webserver for prediction of $\mathrm{N}$ - and $\mathrm{O}$-glycosites in prokaryotic protein sequences. PLoS One. 7, e40155 (2012).

80. J. M. Capasso, C. B. Hirschberg, Mechanisms of glycosylation and sulfation in the Golgi apparatus: evidence for nucleotide sugar/nucleoside monophosphate and nucleotide sulfate/nucleoside monophosphate antiports in the Golgi apparatus membrane. Proc. Natl. Acad. Sci. 81, 7051-7055 (1984).

81. S. Kosugi, M. Hasebe, N. Matsumura, H. Takashima, E Miyamoto-Sato, M. Tomita, H. Yanagawa, Six classes of nuclear localization signals specific to different binding grooves of importin $\alpha$. J. Biol. Chem. 284, 478-485 (2009).

82. D. Chelsky, R. Ralph, G. Jonak, Sequence requirements for synthetic peptide-mediated translocation to the nucleus. Mol Cell Biol. 9, 2487-2492 (1989).

83. J. D. Bendtsen, H. Nielsen, G. Von Heijne, S. Brunak, Improved prediction of signal peptides: SignalP 3.0. J. Mol. Biol. 340, 783-795 (2004).

84. A. K. Kutach, J. T. Kadonaga, The downstream promoter element DPE appears to be as widely used as the TATA box in Drosophila core promoters. Mol. Cell. Biol. 20, 47544764 (2000).

85. Z. Chen, D. Sturgill, J. Qu, H. Jiang, Comparative validation of the D. melanogaster modENCODE transcriptome annotation. Genome Res. 24, 1209-1223 (2014).

86. N. K. Whiteman, A. D. Gloss, T. B. Sackton, S. C. Groen, P. T. Humphrey, R. T. Lapoint, I. E. Sonderby, B. A. Halkier, C. Kocks, F.M. Ausubel, N. E. Pierce. Genes involved in the evolution of herbivory by a leaf-mining, Drosophilid fly. Genome Biol. Evol. 4, 90016 (2012). 
87. E. Lerat, Identifying repeats and transposable elements in sequenced genomes : how to find your way through the dense forest of programs. Heredity 104, 520-533 (2010).

88. P. Degnan, N. Moran, Evolutionary genetics of a defensive facultative symbiont of insects : exchange of toxin-encoding bacteriophage. Mol. Ecol. 916-929 (2008).

89. M. T. Silva, N. M. S. Santos, A. Vale, AIP56: A Novel Bacterial Apoptogenic Toxin. Toxins 2, 905-918 (2010).

90. A. do Vale, C. Pereira, C. R. Osorio, N. M. S. dos Santos, The apoptogenic toxin aip56 is secreted by the type II secretion system of Photobacterium damselae subsp. piscicida. Toxins 9 (2017).

91. L. Pereira, R. D. Pinto, D. S. Silva, A. R. Moreira, C. Beitzinger, P. Oliveira, P. Sampaio, R. Benz, J. E. Azevedo, N. dos Santos, A. do Vale. Intracellular trafficking of AIP56, an NF-KB cleaving toxin from Photobacterium damselae piscicida. Infect. Immun. (2014).

92. A. Stolle, S. Norkowski, B. Korner, J. Schmitz, L. Luken, M. Frankenberg, C. Ruter, M. A. Schmidt, T3SS-Independent Uptake of the Recombinant NleC Effector of Enteropathogenic Escherichia coli Leads to NF- $\kappa$ B p65 Cleavage. Front. Cell. Infect. Microbiol. 7, 1-23 (2017).

93. M. Reis, A. do Vale, C. Pinto, D. S. Nascimento, C. Costa-Ramos, D. S. P. Silva, M. T. Silva, N. M. S. dos Santos, First molecular cloning and characterization of caspase-9 gene in fish and its involvement in a gram negative septicaemia. Mol. Immunol. 44, 1754-1764 (2007).

94. A. do Vale, M. T. Silva, N. M. S. dos Santos, D. S. Nascimento, P. Reis-Rodrigues, C. Costa-Ramos, A. E. Ellis, J. E. Azevedo, AIP56, a novel plasmid-encoded virulence factor of Photobacterium damselae subsp. piscicida with apoptogenic activity against sea bass macrophages and neutrophils. Mol. Microbiol. 58, 1025-1038 (2005).

95. D. S. Silva, L. M. G. Pereira, A. R. Moreira, F. Ferreira-da-Silva, R. M. Brito, T. Q. Faria, I. Zornetta, C. Montecucco, P. Oliveira, J. E. Azevedo, P. J. B. Pereira, S. MacedoRibeiro, A. do Vale, N. M. S. dos Santos, The apoptogenic toxin AIP56 is a metalloprotease A-B toxin that cleaves NF-KB P65, Is a Metalloprotease A-B Toxin that Cleaves NF-кb P65. PLoS Pathog. 9 (2013).

96. L. Guerra, K. Teter, B. N. Lilley, B. Stenerlow, R. K. Holmes, H. L. Ploegh, K. Sandvig, M. Thelestam, T. Frisan, Cellular internalization of cytolethal distending toxin: a new end to a known pathway. Cell. Microbiol. 7, 921-934 (2005).

97. X. Cortes-bratti, T. Frisan, M. Thelestam, The cytolethal distending toxins induce DNA damage and cell cycle arrest. Toxicon 39, 1729-1736 (2001).

35 98. J. R. Zaneveld, D. R. Nemergut, R. Knight, Are all horizontal gene transfers created equal? Prospects for mechanism-based studies of HGT patterns. Microbiology 154, 1-15 (2008).

99. P. J. Keeling, J. D. Palmer, Horizontal gene transfer in eukaryotic evolution. Nat. Rev. Genet. 9, 605-618 (2008).

100. C. Canchaya, G. Fournous, S. Chibani-Chennoufi, M. L. Dillmann, H. Brüssow, Phage as agents of lateral gene transfer. Curr. Opin. Microbiol. 6, 417-424 (2003).

101. A. J. Michael, Evolution of biosynthetic diversity. Biochem. J. 474, 2277-2299 (2017).

102. B. Lacroix, V. Citovsky, Transfer of DNA from bacteria to eukaryotes. MBio. 7, 1-9 (2016).

103. T. Rolland, C. Neuvéglise, C. Sacerdot, B. Dujon, Insertion of horizontally transferred genes within conserved syntenic regions of yeast genomes. PLoS One. 4 (2009). 
104. D. Wheeler, A. J. Redding, J. H. Werren, Characterization of an Ancient Lepidopteran Lateral Gene Transfer. PLoS One. 8 (2013).

105. D. A. Fitzpatrick, M. E. Logue, G. Butler, Evidence of recent interkingdom horizontal gene transfer between bacteria and Candida parapsilosis. BMC Evol. Biol. 8, 1-15 (2008).

106. E. Lyons, B. Pedersen, J. Kane, M. Freeling, The Value of Nonmodel Genomes and an Example Using SynMap Within CoGe to Dissect the Hexaploidy that Predates the Rosids. Trop. Plant Biol. 1, 181-190 (2008).

107. Drosophila 12 Genomes Consortium, Evolution of genes and genomes on the Drosophila phylogeny. Nature 450, 203-18 (2007). 